\title{
Building Society and Governing Intimacy: Gender, Law, and Constructions of Sexuality and Courtship in Late- Nineteenth Century British Columbia
}

\author{
by
}

Laura Anne Lutes

A thesis submitted to the Faculty of Graduate and Postdoctoral Affairs in partial fulfillment of the requirements for the degree of

Master of Arts

in

History

Carleton University

Ottawa, Ontario

(C) 2014, Laura Anne Lutes 


\begin{abstract}
This thesis examines Victorian concepts of courtship, masculinity, and femininity in latenineteenth century British Columbia as they were constructed, perpetuated, and understood through legal trials involving the crimes of seduction and abortion. With a focus on the capital city of Victoria and the interior resource town of Revelstoke, this thesis argues that case files, press reports, and associated political and legal texts allow scholars to gain a better understanding of Victorian ideologies, especially when contextualized within the moral and physical geographies of British Columbia. By paying greater attention to the discourses of gender and sexuality and how they intertwined with changing concepts of governance in late-Victorian British Columbian society, it is possible to have a more in-depth understanding of the province's regional history. While the conclusions of this thesis resonate in a wider literature on the law, gender, and sexuality in this period, they also point to the need for more social histories of nineteenth-century British Columbia in order to better understand the province's (re)making as a settler society and culture.
\end{abstract}




\section{Acknowledgements}

There are so many people I must thank for their part in the completion of this thesis that I could never name them all. I have only survived the process due to the help and support of friends, family, and colleagues. First to my friends and colleagues in the department you helped me focus when work needed to get done and provided distractions when breaks were required. Movies, pints, junk food, rant sessions, and laughter (at times hysterical) made the ride an amazing one. To those friends outside of the department both back home and in Ottawa - you have always helped me step back from my work and take a breather in the "outside" world, something I will be forever grateful for.

To Mom, Dad, Helen, and David - you have all been there for me and I love each and every one of you for the constant and unconditional support you give me, even when we are driving each other insane. I cannot imagine having done this without you guys.

To my defence committee - Your feedback and enthusiasm for my work made the defence an enjoyable experience that I will not forget.

To Joan White - Since the beginning you have been there making sure everything didn't fall apart. Thank you for putting up with me and my numerous questions.

Last but not least I would like to thank my supervisor, Professor John C. Walsh. I would not have survived this experience without your guidance. Your suggestions of relevant literature, your amazing editing, and your ability to debate the pros and cons of a variety of television shows has never failed to make me feel better about my work. You did inspire confidence in me and I cannot thank you enough for finally convincing me that this thesis isn't actually half bad. Thank you for everything John. 
Table of Contents

Abstract....................................................................

Acknowledgements ..........................................................ii

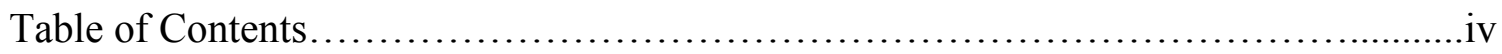

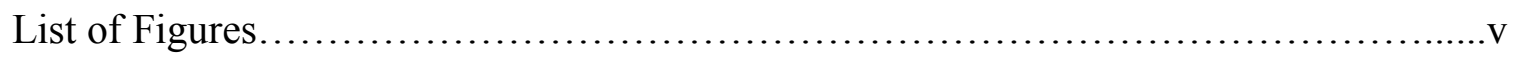

Chapter One: $\quad$ Introduction: Finding Femininity, Masculinity, and

Sexuality in Late-Nineteenth Century British Columbia.............1

Chapter Two: $\quad$ Mapping Geographies of Space and Morality in LateVictorian British Columbia.....................................22

Chapter Three: $\quad$ Late-Victorian Era Seduction and Constructions of Gender and Sexuality..............................................

Chapter Four: $\quad$ The Death of Mary Ellen Janes: Abortion, the Law, and the Construction of Respectable Masculinity in Victoria, British Columbia.............................................8 84

Chapter Five: $\quad$ Conclusion: Gender, Sexuality, and the Regional History of British Columbia.......................................115

Bibliography........................................................ 125 


\section{List of Figures}

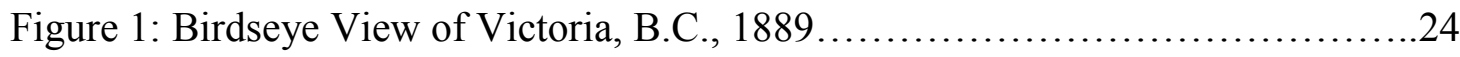

Figure 2: Downtown Victoria, B.C., 1884 - See the edge of the

Songhees Reserve just across the harbour from Johnson Street............27

Figure 3: Slocan Mines, Kootenay District, B.C., 1895 -

This map illustrates how important mining and the C.P.R. was

in the Kootenays................................................... 30 


\section{Chapter One}

Introduction: Finding Femininity, Masculinity, and Sexuality in Late-Nineteenth Century British Columbia

In April 1899, Alexander Featherstone was charged with indecent assault in the town of Revelstoke in the Kootenay region of British Columbia. The charge was brought forward by William Price who was the father of the alleged victim, Thomas Price, a boy of just under eight years old. ${ }^{1}$ Featherstone's testimony regarding what had happened was generally matter-of-fact and to the point. He had taken a walk down to "the mill" and had asked the young Thomas which way to go. Thomas had replied saying he would show him and so they walked together. During their wander around the mill, Featherstone asked Thomas if he liked candy and, when Thomas said that he did, Featherstone gave him twenty five cents to go to the store and get some. After Thomas returned with some candy to share, he and Featherstone sat and chatted. Featherstone then "asked him to show...his penis" and Thomas agreed but did not immediately act, instead following Featherstone into the mill and upstairs. Featherstone described what happened next as follows: "I went up stairs $\&$ he came up to me we sat down $\&$ after a short time I took him on my knee \& asked him to show it to me he did not reply but started laughing." Featherstone urged Thomas not be afraid and promised another twenty five cents if he would comply with the request. Thomas agreed and they sat for approximately fifteen minutes according to Featherstone's testimony before they "got up \& went down.",

Thomas' testimony regarding the incident was much shorter than Featherstone's (a mere few lines), but was similarly matter-of-fact, if not as detailed. Thomas declared

\footnotetext{
${ }^{1}$ Warrant Remanding a Prisoner, file 1899/38, box 1, GR-2355, British Columbia Archives.

${ }^{2}$ A. Featherstone Statement, file 1899/38, box 1, GR-2355, British Columbia Archives.
} 
only that the man had taken him upstairs and had given him thirty five cents (not twenty five cents as Featherstone claimed) to "take out [his] penis," also briefly mentioning that a "teamster [was] hauling lumber through mill below" and reiterating that he was given "35 cents because [he] went up there." ${ }^{3}$ His testimony was matched fairly closely in length by his mother Janey Price's testimony: “Tom told me that that Gentleman took him up in mill put him between his legs \& took it out and rubbed it, he gave him 35C." Though there is some difference in the information provided by Janey, most importantly that Featherstone physically touched Thomas rather than simply looking, the testimonies match in almost all other details.

Though the information included in this case file is limited, we can still gain much from its analysis. There was the matter-of-fact discussion of the incident by both the charged perpetrator and the alleged victim as they reiterated the offer and acceptance of a form of bribe or payment. Even Thomas' mother, who one might expect to be more emotional, was, it would seem, simply sharing the "facts" of the encounter as she heard them from Thomas himself. ${ }^{5}$ The spatial movement of Featherstone and Thomas is also interesting to note as they travelled from the more public location outside the mill, where Featherstone made the initial contact with Thomas and first made his proposition, to the arguably more private (though still technically public) location in the upper part of the mill where the act occurred. When Thomas made the decision to follow Featherstone into the secluded space of the mill, it was no longer a workspace but now a space of

\footnotetext{
${ }^{3}$ Testimony of Tom Price, file 1899/38, box 1, GR-2355, British Columbia Archives.

${ }^{4}$ Testimony of Janey Price, file 1899/38, box 1, GR-2355, British Columbia Archives.

5 In Karen Dubinsky's Improper Advances: Rape and Heterosexual Conflict in Ontario, 1880-1929 (Chicago: University of Chicago Press, 1993), 55, she discusses the matter of fact nature of the testimony from many children regarding instances like this. Dubinsky stresses that it was generally the parents who showed concern or, after finding out about the incident, pursued criminal charges.
} 
danger and, for contemporaries, an (im)moral geography. Featherstone was clearly aware of the immoral and criminal nature of the act while he also had an understanding of where it could be committed. While the particularities of this case differ from the exclusively heterosexual stories of seduction that animate this thesis, this narrative is a good example of how one can think both historically and geographically using case files, as well as how one can think both historically and geographically about gender, sexuality, and power.

Case files similar to Regina v. Featherstone are at the evidentiary heart of this thesis. I analyze these files, and other related archival materials from the late-nineteenth century, to both map and disentangle social constructions of masculinity and femininity as they related to courtship, governance, and the cultivation of a settler society of "white, Christian, middle-class values" and ideals in British Columbia. ${ }^{6}$ The case files under consideration in the following chapters relate most specifically to incidences of seduction and abortion from the late-Victorian era, and they demonstrate how the law was not only intended to punish the offenders, but also to educate and instruct the public about how to conduct themselves as men and women.

As legal historians have taught us, the law is inextricably tied to the political, social, and cultural context from which it was created and applied. The law is historically always in flux. ${ }^{7}$ Case studies using the law and legal documents, therefore, cannot be understood outside of their historical context. Situating the law into context is essential

\footnotetext{
${ }^{6}$ Mimi Ajzendstadt, "Cycles of Control: Alcohol Regulation and the Construction of Gender Role, British Columbia 1870-1925," International Journal of Canadian Studies, 11 (Spring 1995), 108.

${ }^{7}$ Tina Loo makes a similar point in Making Law, Order, and Authority in British Columbia, 1821-1871 (Toronto: University of Toronto Press, 1994), 12, when she states, "it is impossible to understand nineteenth-century British Columbia, its legal system, and the ensuing conflicts over the system without first understanding the fur trade period, for it was during this time that the initial links between law and economy were forged."
} 
to how historians can and should read them (a point I address later), but also how a set of documents became "case files" in the first place. To put this another way, to understand the narratives of criminality that emerge from case files is entirely reliant on where and when these acts took place; for this thesis, this historical geography is late-nineteenth century British Columbia.

On 20 July 1871, British Columbia joined confederation and officially became Canada's westernmost province. Geography, size and location all served to keep the province fairly isolated from the rest of Canada. The Rocky Mountains created the most concrete physical division between British Columbia and the more easterly sections of the country while the province's river valleys, mountain chains, variable climates and regional zones also served to create distinct separations within the province itself. All of these factors created and perpetuated almost mythical understandings of British Columbia both in the written historical record and, at times, among the colonial population itself. ${ }^{8}$ Despite this, many scholars argue that the actual identity of the province and the varied people living there has remained elusive to not only the population of the province themselves but also to its historians. ${ }^{9}$

Though elusive, there was some kind of consensus regarding British Columbian identity by the end of the nineteenth century. This identity was informed by the resourcebased economy and the presence of the stereotypical white, male adventurer and

\footnotetext{
${ }^{8}$ As Chad Reimer discusses in Writing British Columbia History, 1784-1958 (Vancouver: UBC Press, 2009), 5, the written history of British Columbia tended, from the very beginning, to perpetuate these myths as ideas of what many early historians felt was the "the very unmodern dominance of geography over history, of nature over humanity," were discussed at length as part of society's attempts to create a province based on European ideals and ideologies.

${ }^{9}$ Jean Barman, The West Beyond the West: A History of British Columbia, Third Edition (Toronto: University of Toronto Press, 2007), 3-4; Reimer, Writing British Columbia History, 6, also speaks to this elusive British Columbian identity while also discussing the importance of using history to form the identity of a specific society.
} 
increasingly the transient, white, male labourer who was doing the "hard work" of building a modern province. Though the province was home to some of the most varied and diverse groups of First Nations in Canada (and continues to have one of the most diverse populations to this day), earlier generations of British Columbia's historians perpetuated the stereotypes of this white male figure as one of the central features, if not the central feature, of the province's past. ${ }^{10}$ While the importance of this figure (both as an adventurer and as a labourer) should not be underestimated, here my interest is in how this gendered, racialized, and classed identity was, like the province itself, in a state of (re)making in the late-nineteenth century. ${ }^{11}$ In particular, my thesis addresses how the regulation of sexuality and gender relations was integral to defining and defending whiteness. To this end, I therefore locate this thesis in a more recent historiography of British Columbia that has been inspired by feminist and post-colonial theory. ${ }^{12}$

My thesis shares the same critical stance as historian Adele Perry's influential scholarship on the province. There are also important differences, however. Perry's work is focussed on the middle decades of the nineteenth century and generally ends with British Columbia's entrance into Confederation in 1871, while I focus on the late-

\footnotetext{
${ }^{10}$ Cole Harris' The Resettlement of British Columbia: Essays on Colonialism and Geographical Change (Vancouver: UBC Press, 1997) is one work that attempts to provide a more in-depth look at the interactions between the First Nations of British Columbia and the European colonizers and the different power dynamics that existed at the time. Barman's The West Beyond the West and Adele Perry's On the Edge of Empire: Gender, Race and the Making of British Columbia, 1849-1871 (Toronto: University of Toronto Press, 2001) also provide good examples of how provincial histories of British Columbia can be more analytical and in-depth rather than simple perpetuations of stereotypes and broad, almost mythical, narratives. These historians are working to move away from this simplistic style of history.

${ }^{11}$ For a pioneering discussion of how masculinity and gender ought to be discussed more critically in relation to every day processes (such as labour) see Steven Maynard's "Rough Work and Rugged Men: The Social Construction of Masculinity in Working-Class History," Labour/Le Travail, 23 (Spring 1989), 159169.

${ }^{12}$ Constructions of whiteness are deeply rooted in Canadian constructions of their own identities, something that is discussed well in Andrew Baldwin, Laura Cameron, and Audrey Kobayashi's work Rethinking the Great White North: Race, Nature, and the Historical Geographies of Whiteness in Canada (Vancouver: UBC Press, 2011).
} 
nineteenth century. While themes of state and society building, gender, sexuality, class, and race are at the centre of Perry's work and also inform mine to a large degree, they do so from within a different context. These chronological and contextual differences between Perry's work and my own, as well as the shared themes, must be taken into account. In this respect, no change was more important than the differences in state formation, industrialization, and urbanization.

When the province joined confederation, some European inhabitants believed British Columbia was entering a new era while others were more practical in their assumptions that things would stay much the same in their far-western corner of Canada. Middle and upper class residents in the capital Victoria felt they would remain comfortably in control of the "political, legal and social structures" of the new province. ${ }^{13}$ Their attempts to construct a liberal society in British Columbia would continue at least unchecked, if not greatly aided, by the federal government in Ottawa as the "formal change in status from colony to province... did not alter the fact that the colonial processes designed to bring the territory and indigenous peoples under settler control were only just beginning." ${ }^{14}$ This was a situation not unfamiliar to British Columbians as they had previously been left to their own devices by the British as well. ${ }^{15}$ The preconfederation period in British Columbia was generally understood as a time of exploration and expansion on the part of white Europeans as they searched for new trade routes and more resources while also developing both mining and forestry industries in

\footnotetext{
${ }^{13}$ Barman, The West Beyond the West, 104.

${ }^{14}$ Douglas C. Harris, Fish, Law and Colonialism: The Legal Capture of Salmon in British Columbia (Toronto: University of Toronto Press, 2001), 199-200.

${ }^{15}$ Perry, On the Edge of Empire, 13; Barman, The West Beyond the West, 96.
} 
the area. This resource-based society, plus the influx of American miners due to multiple gold rushes in the mid and late 1800 s combined to create a very distinct population. ${ }^{16}$

As scholars have convincingly argued, the concentration of so many white, male labourers within the more diverse First Nations population meant that a "rough, homosocial culture" in the backwoods of British Columbia was created, perpetuated, and, from the capital city Victoria, begrudgingly tolerated by the governing classes, as long as the work of wealth- and resource-extraction continued. Yet, as is evident when looking at the work of scholarship produced by Perry, Jean Barman, Tina Loo, Gillian Creese, and Veronica Strong-Boag, ${ }^{17}$ the politics of this culture underwent some important changes in the decades right before, during, and after 1871 as it became increasingly at cross-purposes to the "colonial visions" held by many of the new province's reformers as they attempted to "promote a model of bourgeois, metropolitan manhood."18

While much of this social historical research discusses these histories of gender, race, sexuality, population, the law, and culture in the pre-confederation period in British Columbia, colonial ideologies also existed post-confederation and continued to inspire

\footnotetext{
${ }^{16}$ Barman, The West Beyond the West, 65.

${ }^{17}$ These scholars have been immensely important in the re-forming of British Columbian history. Jean Barman took the stage in the 1990s as one of the first historians of British Columbia, if not the first, to incorporate concepts of race, gender, class, and sexuality into a broad regional history that looked at the changing contexts of the province. Not only that but she explicitly discusses the lack of First Nations women in past academic work about British Columbia, arguing that it is an essential part of the province's identity and history and, as such, must be discussed, especially in broad histories. The West Beyond the West and "Taming Aboriginal Sexuality: Gender, Power, and Race in British Columbia, 1850-1900," BC Studies, 115/116 (Autumn/Winter 1997/98), 237-266 are two of her most well-known works due to their analytical discussions of British Columbian history. Veronica Strong-Boag and Gillian Creese's work similarly brings gender into focus more analytically, providing a way of reading British Columbia's history in a more dynamic and critical way, something that is apparent in their article "Taking Gender into Account in British Columbia: More Than Just Women's Studies," BC Studies, 105/106 (Spring/Summer 1995), 926. They use this article to illustrate some of the ways they have worked towards a more critical understanding of British Columbia's history while also providing ideas for how others can do so as well. Tina Loo's work Making Law also looks at the changing contexts of British Columbian society, particularly in relation to the law and the pre-confederation years, and is yet another way the history of this province has been written in a more analytical fashion.

${ }^{18}$ Perry, On the Edge of Empire, 79.
} 
fears of improper male interaction with other males and Aboriginal women. ${ }^{19}$ This postconfederation context is where I situate my thesis and overall attempt to come to terms with ideas of moral regulation and governance and how they related to the aforementioned and socially constructed ideas of masculinity, femininity, sexuality and courtship. The societies that existed in these labour camps and resource-based towns in the British Columbian interior did not fit accepted "Victorian social norms" or ideals. This was in part because, for many of the British settlers, it was hard to reconcile the racially diverse and mainly male settler society with ideals that had originated in "midnineteenth century dreams of sober, hard-working men, virtuous women and respectable families" and only continued to persist as the governing classes attempted to mould their society. These attempts to form society were matched by changing ideas about proper masculinity as well with the cultivation of a new and improved masculinity for the working classes of the province. ${ }^{20}$ This was the goal, however, and despite these concerns (even possibly because of them), late-Victorian era ideals and social norms continued to serve as a model for the cultivation of British Columbian society.

One key part of this model was the figure of the white woman. During the earlyand mid-nineteenth century, the figure of the white woman took on an almost mythical quality as the icon of civilization in a society that was racially diverse and largely devoid of such figures. This inspired worries among the white colonial elite about how to build a "proper" or morally correct society. White women were viewed as the ultimate

\footnotetext{
${ }^{19}$ Christopher Clarkson, "Remoralizing Families? Family Regulation and State Formation in British Columbia, 1862-1940," (Unpublished PhD Dissertation, Department of History, University of Ottawa, 2002), 39.

${ }^{20}$ Perry, On the Edge of Empire, 17.
} 
"civilizing agents" by many colonial reformers ${ }^{21}$ and not only that, but the "heterosexual, nuclear family form" was understood as a key base for society. ${ }^{22}$ The Canadian west was promoted even in eastern provinces as a place to "foster happy families," something that required both white men and women. ${ }^{23}$ How did one create a "civilized" society without white women? Without white women there could be no nuclear family and without the family unit, a capitalist society was missing a crucial piece of its support structure.

The dominant homosocial culture of the British Columbian backwoods and the ongoing sexual (and at times romantic) interactions between men as well as between white men and Aboriginal women was viewed by many politicians and church reformers as detrimental to the social good. This "nascent, highly mobile, male working-class culture" existed in British Columbia most specifically due to the resource-based economies and the combination of "independent commodity production with wage labour," and was considered a problem by colonial reformers. ${ }^{24}$ It is within this context that historians identify the construction of the mythical white male as a key agent of British Columbian society. They were present in droves but, without white women to form, mould and regulate them, there was no hope for the development of a "proper" society. This in itself illustrates the warring ideals of the governing classes of the latenineteenth century as they tried, very self-consciously, to move away from an identity tied to these sojourners and build a modern and "civilized" social order that conformed to the proper values of the permanent, nuclear family based, Victorian society.

\footnotetext{
${ }^{21}$ See Barman, The West Beyond the West; Loo, Making Law; Perry, On the Edge of Empire; and Creese and Strong-Boag, "Taking Gender into Account," for discussions of colonial understandings of white women as civilizing agents in British Columbia.

${ }^{22}$ Maynard, "Rough Work and Rugged Men," 168; Clarkson, "Remoralizing Families?" 8, 39.

${ }^{23}$ Lesley Erickson, Westward Bound: Sex, Violence, the Law, and the Making of a Settler Society (Vancouver: UBC Press, 2011), 22.

${ }^{24}$ Perry, On the Edge of Empire, 16.
} 
Perry discusses the tendency on the part of academics to use, whether implicitly or explicitly, two particular frameworks to talk about the presence (or lack) of white women on the frontier. According to Perry, however, these frameworks only further simplify the history under discussion when used improperly. The first is the "scarcity model," based on the idea that "women's experience improves commensurate with their rarity." She adeptly compares this framework with the economic theory of supply and demand. ${ }^{25}$ The second model, called the "volcano theory," is a theory of male sexuality that assumes a "fixed quantity (always unspecified) of male sexual energy which, if not funnelled into monogamous, same-race heterosexual relationships, 'will burst forth in a variety of 'deviant' behaviours." ${ }^{26}$ This model most explicitly relates to this thesis as the case files I use illustrate some of the incidents where the sexual energy of males, whether real or perceived, became criminalized. An example of this can once again be seen in the case file from the beginning of this chapter. In Regina v. Featherstone, the supposedly uncontrollable passion of Featherstone was deemed to have created this immoral and criminal situation. A "proper" Victorian gentleman would have been able to control his urges if he had even had them in the first place. ${ }^{27}$

\footnotetext{
${ }^{25}$ Adele Perry, “'Oh I'm Just Sick of the Faces of Men': Gender Imbalance, Race, Sexuality, and Sociability in Nineteenth-Century British Columbia," BC Studies, 105/106 (Spring/Summer 1995), 27-28. ${ }^{26}$ Perry, "'Oh I'm Just Sick of the Faces," 28-29; A discussion of these ideas of male sexuality can be found in the work of William Acton, a nineteenth-century British doctor and writer, entitled The Functions and Disorders of the Reproductive Organs in Childhood, Youth, Adult Age, and Advanced Life: Considered in Their Physiological, Social and Moral Relations. Published in 1857 in London, England, the book provides a discussion of male reproductive functions almost exclusively. When women were discussed it was generally in relation to their lack of interest in sex and how they were part of men's experiences with sexuality. Acton's work further perpetuated ideas about archetypal women, namely the asexual and innocent woman, an archetype that was placed in opposition to what were believed to be the sometimes uncontrollable urges and passions of men.

${ }^{27}$ Maude C. Cooke, Social Etiquette or Manners and Customs of Polite Society (London, ON: McDermid \& Logan, 1896), 116; John Tosh, "Masculinities in an Industrializing Society: Britain, 1800-1914," Journal of British Studies, 44, 2 (April 2005), 336.
} 
As Perry makes clear, both models are based on "essentialist notions of race and sexuality" that simplify incredibly complex processes in frontier societies more generally and, in the case of this thesis, late-nineteenth British Columbian society specifically. Part of the problem with the use of these models by academics is that there tends to be a lack of understanding about their historical origins. Both models of sexuality were invoked by colonial promoters of the nineteenth century, and were active elements of colonial discourse. Rather than explaining the nineteenth century, therefore, these models help histories such as this thesis to make sense of how Victorians understood sexuality and sought to manage it as a social and political issue. ${ }^{28}$

\section{Reading Sexuality and Intimacy in the Archive}

In this thesis I use case files and newspaper articles to look at crimes of seduction (a term with various meanings during the late-Victorian era) and a case involving abortion. Though these crimes occurred in the past, as a historian there are still very close ties to the present through these narratives. The cases discussed in this thesis are such that they inevitably evoke emotion or empathy in the reader. They are not simply nuisance crimes or even crimes of vagrancy or theft. Rather, these are cases about deeply personal and intimate social relationships of courtship and sexuality. Reading about instances of forced sexual intercourse and the death of a young woman due to a botched abortion evoke very real emotions for readers of these files, even more than a century later. Emotion is something many academics attempt to suppress as it is felt to be too subjective for proper source analysis. Though this may be true to an extent, there is something inherently subjective about reading case files and the newspaper articles that

${ }^{28}$ Perry, “'Oh I'm Just Sick of the Faces,” 31. 
pertain to them and, as a historian, I work to both balance the emotion involved in the acts themselves while also acknowledging the almost sterile package they come in when viewed through the window of the case file. This sterility is something that sometimes plagues histories of the law, as opposed to social and cultural legal histories that are written in an attempt to pay some attention to the inherent emotion and subjectivity of the sources, such as those featured in this thesis. ${ }^{29}$

Legal history as well as other fields involving the research and analysis of the law have in many ways, been considered technical or "factual" methods for gaining information regarding the law and even intentions behind the creation of law. This is in part due to the fact that the law is created and implemented by the governing power and so has the weight of institutional power behind it. In the past this was not a factor that was always taken into account when examining the law and as such there was an assumption due to the power behind the law that it was "factual." This in turn led to an assumption of supposed truth behind the law. These assumptions about fact and truth, concepts that, though related, do differ, are now more critically understood by scholars. ${ }^{30}$

\footnotetext{
${ }^{29}$ Canadian historians of the law such as Karen Dubinsky, Constance Backhouse, and Lesley Erickson are just some of the scholars working to move away from this type of legal history by attempting to resist the seeming sterility of it by using the law as a window into social and cultural history. While more interested in state formation and governance, Tina Loo also balances a history of the law with a more focussed look at how it interacts with the populations of people on whom it is imposed and with whom it is intertwined.

${ }^{30}$ There are various works that illustrate the use of the law and related sources to gain a better understanding of historical social norms, situations and contexts including but not limited to the work of John McLaren, Robert Menzies and Dorothy E. Chunn's, eds., Regulating Lives: Historical Essays on the State, Society, the Individual and the Law (Vancouver: UBC Press, 2002); Erickson's, Westward Bound; Hamar Foster's English Law, British Columbia; Establishing Legal Institutions West of the Rockies (Winnipeg: University of Manitoba, Faculty of Law, 1992); Cole Harris', The Resettlement of British Columbia; Douglas C. Harris', Landing Native Fisheries: Indian Reserves and Fishing Rights in British Columbia, 1849-1925 (Vancouver: UBC Press, 2008) and Fish, Law and Colonialism; John McLaren's "Chasing the Social Evil: Moral Fervour and the Evolution of Canada's Prostitution Laws," Canadian Journal of Law and Society, 1 (1986), 125-166; Constance Backhouse's Petticoats and Prejudice: Women and Law in Nineteenth-Century Canada (Toronto: Osgoode Society, 1991); Loo's Making Law and Tina Loo and Carolyn Strange's Making Good: Law and Moral Regulation in Canada, 1867-1939 (Toronto: University of Toronto Press, 1997) .
} 
Inspired by this form of critical legal history, I therefore read political debates and the writing and re-writing of legislation and the Criminal Code to better understand the hegemonic cultural constructions and normalization of masculinity and femininity in latenineteenth century British Columbia.

I take a slightly different constructivist approach to how I read the case files, one in which I think even more about the making of the case file as a historical document. Case files are composed of notes, testimonies, transcripts and correspondence that accumulate in reference to a specific inquiry or court case. These document collections can enable historians to gain a much better understanding of the specificities of particular cases which, in turn, can allow a better understanding of the complex interactions among those involved as well as the broader context of the time in which the case took place. Case files, then, are beneficial for historians as they can provide insight into these past constructs and histories. They can also be problematic as with these benefits come issues that are specific to case files, including but not confined to concerns over how they should be read, understood and used. Part of this issue is that case files are, in part, how the "facts" of a case become archived and, through this, legitimized as "fact." To put another way, case files do not simply document what happened, they also document how contemporaries came to know and represent what happened.

One of the problems with case files and legal documents is the desire on the part of those using them that the documents included in these sources provide the "real truth" about a particular time, incident or person. This can again be tied back to understandings of the law itself as factual and truthful, in part due to the institutional power that lies behind the creation and implementation of said laws. Case files are then read as windows 
into the implementation and enforcement of these laws which only seems to add to their legitimacy as sources of fact and truth. Though this assumption is recognized as problematic, it is easy to fall into this trap and use these sources without enough analytical reflexivity, creating an overly simplistic view of the situation or people involved. ${ }^{31}$ The information that can be gained through reading case files cannot be read as an "unmediated text on a person's life." 32

Consider, for example, the case of Thomas Price whom we met at the very start of this chapter. When Thomas testifies he does so within an institutional setting that constructs him as a child with an inability to make his own decisions. He has not brought the charges against Featherstone, his father has, and his testimony does little to condemn the perpetrator though his mother's testimony does. The information Thomas provides in his limited testimony is mediated by his age, the presence of those taking his testimony and (one might assume) the presence of his parents. There is still, however, an illusion of readily accessible and unqualified information that comes in part from the sheer volume of information provided in case files as well as the seemingly factual nature of the information. By the same token, the women and men of the case files I analyze in this thesis are telling their stories within the structure of the legal system. The question then becomes how to analyze such a large amount of information and even, if needed, what to exclude while also acknowledging the inherent problems with such sources. ${ }^{33}$

\footnotetext{
${ }^{31}$ Franca Iacovetta and Wendy Mitchinson, "Introduction: Social History and Case Files Research," in On the Case: Explorations in Social History, eds. Franca Iacovetta and Wendy Mitchinson, (Toronto: University of Toronto Press, 1998), 3.

${ }^{32}$ Iacovetta and Mitchinson, "Introduction," 5.

${ }^{33}$ Carolyn Strange, "Stories of their Lives: The Historian and the Capital Case File," in On the Case: Explorations in Social History, eds. Franca Iacovetta and Wendy Mitchinson (Toronto: University of Toronto Press, 1998), 31.
} 
The case files must be treated differently in some ways than other sources because their very existence as sources implies the "intervention of institutional and bureaucratic power into people's lives."34 Though this applies to many sources in colonial and state archives, such as that of late-Victorian British Columbia, these ideas must especially be kept firmly in mind by historians when using case files as sources. ${ }^{35}$ This intervention of the state through the actions of the court is apparent in the context of many of the cases I will be discussing in the following chapters of this thesis. In these cases, officials, or even at times family members as in the Featherstone and Price case, clearly felt that the intervention of the state into the lives of these people was justified. This was partly due to what Chris Clarkson identifies as the shifting locus of patriarchy which had not disappeared in the late-Victorian era but had "simply shifted from individual household heads to legislators and judges." ${ }^{, 36}$ Not only that, but the people who wrote and then published the many newspaper articles that can be found discussing particular cases also felt that the information they were disseminating was relevant to the public at large. These situations and the people involved in them were viewed "through the hostile eyes of one of the systems that helped to sustain class and ethnic hierarchy" as well as gender norms and categories in society both at the time and in the present day. ${ }^{37}$

Particularly when working with case files such as those I am using, there must be a clear understanding of them as historical sources, something which must also include an

\footnotetext{
${ }^{34}$ Iacovetta and Mitchinson, "Introduction," 6.

${ }^{35}$ See Sarah de Leeuw for a discussion of very similar ideas in relation to colonialism in British Columbia in her article "Alice through the looking glass: emotion, personal connection, and reading colonial archives along the grain," Journal of Historical Geography, 38 (2012), 273-281.

${ }^{36}$ Chris Clarkson, Domestic Reforms: Political Visions and Family Regulation in British Columbia, $1862-$ 1940 (Vancouver: UBC Press, 2007), 83.

${ }^{37}$ Karen Dubinsky, "Afterword: Telling Stories About Dead People," in On the Case: Explorations in Social History, eds. Franca Iacovetta and Wendy Mitchinson (Toronto: University of Toronto Press, 1998), 361 .
} 
acknowledgment of the possible emotional attachment that a reader might form when working closely with them. As previously discussed case files involving interactions such as rape, seduction, abortion and indecent assault will inevitably lead to a more emotional interaction than files focussing on nuisance crimes. The people involved in and affected by these situations, and further having their experiences and identities portrayed in these files and press reports, were not fictional characters but were real people. At times, their testimonies and the subsequent dramatized press narratives regarding a particular event in their lives, made them seem closer to the present day and the reader. Narratives emerge and, particularly in cases that might involve seemingly unfair or archaic situations when read by a modern day reader (such as contentious situations like seduction and abortion), arguably draw in even the most analytical reader, adding an emotional side to the aforementioned assumptions of truth that can come with legal sources. This, in turn, can lead to even stronger empathy and a distinct shift from more objective analysis to a subjectivity that can negatively impact a researcher's ability to fully scrutinize the evidence at hand.

By merely telling the story with little or no analysis, the work of historians can perpetuate particular discourses, especially those regarding gender and race, that we as historians could (and some even argue should) be working to change. That being said, however, one must not completely cease to empathize with all the people found in these sources, even those with whom we might feel deeply estranged. A balancing act of sorts must occur as we historians attempt to tell the stories of these people, and yet maintain enough distance that we can attempt to better understand and qualify the information gathered within contemporary understandings and contexts. 
Sarah de Leeuw looks at these issues of researcher emotion and empathy through the lens of colonialism and particular relationships between the Indigenous population of British Columbia and European settlers. ${ }^{38}$ De Leeuw focusses particularly on Alice Ravenhill, an immigrant from England who moved to British Columbia in 1910. De Leeuw looks at how, through her own research on Alice, she formed an attachment to Ravenhill that drew the past ever closer to the present while she also strove to maintain her ability to perform critical analytical and useful research. Though it may not appear so right away, the concepts de Leeuw discusses can also be applied to many case files as sources. As de Leeuw points out, historical and archival research is "subjective and emotional work with political ramifications. ${ }^{\prime 39}$ Though there was a strong movement towards reading sources "against the grain" by many historians, de Leeuw follows Ann Laura Stoler's argumentation when she insists that we ought to read "along the grain" as well. ${ }^{40}$ She differentiates between reading with and reading along stating that "with" implies "passively accepting the archival record" while "along...requires a committed, impassioned and emotive response to the archival record." ${ }^{41}$ De Leeuw argues that reading "against the grain" can distance the past from the present which can, in turn, cause the reader to lose sight of the historian's own place in the perpetuation of the ideas in these sources. However, as previously mentioned, we historians can, and must, walk the line between this emotional subjectivity and the more nuanced analytical discussion

\footnotetext{
${ }^{38}$ de Leeuw's analysis is heavily influenced by Ann Laura Stoler's Along the Archival Grain: Epistemic Anxieties and Colonial Common Sense (Princeton: Princeton University Press, 2009).

${ }^{39}$ de Leeuw, "Alice through the looking glass," 274.

${ }^{40}$ This technique is apparent in Sylvia Van Kirk's Many Tender Ties: Women in the Fur-Trade, 1670-1870 (Norman: University of Oklahoma Press, 1980) which was one of the first key works in Canadian history to read sources "against the grain" as she used British archives and "official" sources to find women in a time and place where it had previously been argued they simply did not exist. This work brought into question ideas about "official" sources and how they could be used to find those previously forgotten or left out of history.

${ }^{41}$ de Leewu, "Alice through the looking glass," 275.
} 
that must occur when looking at all sources, be they case files, newspaper articles or the personal documents of a colonizer.

Case files are vital in helping me disentangle the contemporary understandings of gender and sexuality and how the implementation of the law in late-nineteenth century British Columbia was part of particular constructions of masculinity and femininity as they related to courtship and, through courtship, the attempted formation of a particular type of society - a society that fit Christian and European ideals. One way of accomplishing this is by analyzing case files in conjunction with other sources such as census data, maps, government legislation and newspaper articles, much as Patrick Dunae does in his study of sex trade workers in late-Victorian-era Victoria. Dunae works through the process of linking census data to case files, police records and maps to geographically locate brothels and women working in them. In doing so, Dunae is able to map the moral geography of the city with nuance and specificity. ${ }^{42}$ His method is particularly useful due to the fact that people and places like those discussed in his study, as in my own, are sparse in official records and thus can be elusive in the historical record as well. ${ }^{43}$

\footnotetext{
42 Patrick Dunae, "Sex, Charades and Census Records: Locating Female Sex Trade Workers in a Victorian City," Histoire Sociale/Social History, 42, 84 (November 2009), 278-279; See Felix Driver's "Moral Geographies: Social Science and the Urban Environment in Mid-Nineteenth Century England," Transactions of the Institute of British Geographers, 13 (1988), 275-287 and Mona Domosh's "Toward a Feminist Historiography of Geography," Transactions of the Institute of British Geographers, 16 (1991), 95-104 for examples of how geographies have been analyzed and discussed in relation to both morality and feminism.

${ }^{43}$ Working at a close level with census records, press reports, and legal documents as Dunae does is something that I do most fully in Chapter Four of this thesis where I focus most particularly on one case file (Regina v. Garrow and Creech) and the people involved with it. It must also be understood, however, that such tactics are not unlike others used by academics in that they do have limits. In some of the press reports and case files I use in Chapter Three I am unable to piece together more information about the lives of those who people my thesis. This could be due to their movement from place to place, their age, changed names, or even misspelled names.
} 
What can be concluded using these sources is, among other things, how the law was used by well-placed members of the society to affect change, and to govern and mould society (something particularly apparent in the European colonialism of the latenineteenth century). ${ }^{44}$ Theories of social control, moral regulation and governmentality can be understood, in conjunction with these sources as they intertwine and exist both within institutions of power and within the population being governed. Courts, the law and even the press were part of a system whereby the governance of a population occurred subtly through constant negotiation. ${ }^{45}$ Historians can therefore use case files, census records, maps and newspaper articles to chart the moral geography of a particular place and, through this, better understand changing notions of masculinity, femininity and sexuality. French philosopher and theorist Michel Foucault touches on these issues often in his work where he focusses mainly on discussions of power, knowledge, and discourse. ${ }^{46}$ His theory of governmentality was built upon his earlier work on these concepts and became a key part of the evolution of the later theorization of moral regulation by others. $^{47}$

\footnotetext{
${ }^{44}$ Harris, Fish, Law, and Colonialism, 186.

45 As social control theory has sometimes been viewed metaphorically as a hammer, Loo and Strange (Making Good, 5) argue that moral regulation can helpfully be discussed as a net which is, while still "restrictive [also] full of holes," and allowing for agency or resistance to slip through. This allows for more useful discussion of governed populations as it creates an understanding of state control and power as constantly shifting as the power between the measures taken by the state and the population being governed is also constantly negotiated.

${ }^{46}$ Two major works where these concepts can be found are in Michel Foucault's, The Archaeology of Power and the Discourse on Language, trans. A.M Sheridan Smith (New York: Pantheon Books, 1972) and The History of Sexuality, trans. Robert Hurley (New York: Pantheon Books, 1978).

${ }^{47}$ Michel Foucault, Power, trans. Robert Hurley, ed. James D. Faubion (New York: The New Press, 1994), 219-220. Governmentality first appeared in a lecture given by Foucault on 1 February 1978 as part of a series entitled Security, Territory, Population. Foucault provided a three pronged definition for governmentality. Definition one points to the "ensemble" of traits that make up government that, "allow the exercise of this very specific...power that has the population as its target, political economy as its major form of knowledge, and apparatuses of security as its essential technical instrument." His second point is the discussion of the line of power that has, specifically in the West, been seen as leading to the preeminent type of power (government) which has resulted in the, "formation of a whole series of specific
} 
As scholars in the 1990s grew weary of social control theory, moral regulation became a conceptual middle ground for scholars who wanted to look more closely at the subtle interactions and regulation between the state and the population more generally but also among members of the population themselves. ${ }^{48}$ Foucault's discussions around the "often diffuse and diverse nature of disciplinary power" and "the reality of resistance within populations to whom power and authority are applied" were especially influential. $^{49}$ They also speak well to my own archive and research questions. The case files analyzed in this thesis are revealing documents for how moral regulation was affected in late Victorian British Columbia. The men and women involved in the cases under consideration were not being completely controlled by the law or state. Even in the disciplinary context of trials and through testimony, we shall see people negotiating their identities and, through this, their treatment by the law. Whether this was done on purpose or unintentionally is not always clear, but the constructions of masculinity and femininity that emerged because of it simply reinforced ideas about the shifting nature of morality. More than this, however, the use of these theories is about trying to understand the

governmental apparatuses" and the "development of a whole complex of knowledges." Foucault's final point is that we should understand governmentality as a result of "the state of justice of the Middle Ages" as it transformed throughout the fifteenth and sixteenth centuries, gradually becoming closer to the modern day administrative state and becoming, as Foucault says, "governmentalized." These definitions were influential in the discussion of what McLaren, Menzies and Chunn call "other sources of social disciplining" in their edited book Regulating Lives (pg. 11). The interplay and articulation of power and knowledge in the context of moral regulation is especially visible when it becomes codified in the law.

${ }^{48}$ Social control was the previously preferred term used by academics in history and other social sciences to describe what Carolyn Strange and Tina Loo call the "state's power over citizens" in Making Good (5). The term was found to be problematic, however, as, in the 1960s, it gained more negative connotations due to use by "radical sociologists" who used it as a way to "explain how authority is maintained in a conflictridden society" - Lucia Zedner, "Social Control," in The Blackwell Dictionary of Modern Social Thought, eds. William Outhwaite and Alain Touraine (Malden, MA: Blackwell Publications, 2003), 597. Theories of moral regulation arose as a critique of social control theory as well as due to discussion around later work by Foucault.

${ }^{49}$ John McLaren, Robert Menzies and Dorothy E. Chunn, "Introduction," in Regulating Lives: Historical Essays on the State, Society, the Individual, and the Law, eds. John McLaren, Robert Menzies, and Dorothy E. Chunn (Vancouver: UBC Press, 2001), 11. 
attempts by governing classes to educate and nurture populations to the point of selfgoverning, and this form of liberalism was very much in the ascendancy in the court rooms and in the newspapers examined in this thesis.

To explore all of this in more detail, the following three chapters move increasingly from the broad to the specific. Chapter Two establishes more explicitly the historical and geographical terrain in which cases of seduction and abortion emerged in both the capital city of Victoria and in the interior resource towns of the Kootenays (especially Revelstoke). Chapter Three discusses seduction as a legal issue by using multiple case files to show how it was understood and used as a tool for education and governance when brought before the courts. Both case files and newspaper articles are used as sources here. Seduction served as something of a criminal middle ground between "proper" courtship gone awry and ending in a possible pregnancy or, even worse, the young woman's descent into the "social evil" of the day: prostitution. Chapter Four offers a deep, sustained analysis of the last days and subsequent legal proceedings surrounding Mary Ellen Janes of Victoria, who died from the effects of a botched abortion. Here we see the constructions of both femininity and masculinity in a sensationalized case that questioned morality, sexuality, and propriety, as well as offering the most intimate, personal, and emotionally difficult case I encountered in the archive. 


\section{Chapter Two}

Mapping Geographies of Space and Morality in Late-Victorian British Columbia

Two particular regions of British Columbia, the Kootenay region of the interior and the capital city Victoria on Vancouver Island, are at the geographical centre of this thesis. This chapter's goal is rather straightforward; it seeks to establish the specific historical geographies (moral, social, and economic) where the cases under discussion unfolded. Both the broader contexts of the late-Victorian era and local dynamics of place and community are essential to any analysis of case files. Though constantly informed by the broader provincial, national, and international movements of social purity and Victorian ideas about gender, sexuality, and courtship, each location was also unique with respect to its social and spatial landscapes. It is the dynamic between the trans-local and the local which produced the moral geographies and forms of moral regulation that are interrogated in the case files under discussion in the next two chapters.

In 1843, the Hudson Bay Company founded a fur trade post that would come to be the city of Victoria, British Columbia. Though founded in the early 1840 s, Victoria was only incorporated as a city in the 1860 s and given the title of capital of the combined colony of British Columbia in 1868, taking the honour from the city of New Westminster on the mainland. ${ }^{1}$ In 1886, the Canadian Pacific Railroad (CPR) arrived on the west coast and brought the area "more in line with southern Canadian social patterns" with its arrival. $^{2}$ The city of Victoria specifically also followed this line of change as during the

\footnotetext{
${ }^{1}$ Jean Barman, The West Beyond the West: A History of British Columbia, Third Edition (Toronto: University of Toronto Press, 2007), 96.

2 Adele Perry, "From 'the Hot-Bed of Vice' to the 'Good and Well-Ordered Christian Home': First Nations Housing and Reform in Nineteenth-Century British Columbia,” Ethnohistory, 50, 4 (Fall 2003), 589.
} 
last decades of the nineteenth century it "discarded vestiges of its frontier, fur-trade-post origins and emerged as a prosperous, modern North American city."3

Located on the southern end of Vancouver Island and found within the traditional territory of the Lekwungen First Nation, Victoria has deep harbours which provided easy exits for trade goods, one of the key reasons for it being chosen as the main fur trade post on the Island and the Hudson's Bay Company's "colonial capital." It was also, according to the 1893 Hand-Book and General Guide to British Columbia, "remarkable for its delightful situation and the beauty of its surroundings." Not only that, but the booster pamphlet also insisted that Victoria had a "perfect water system, gas, and electric light" as well as "electric tram-cars... on principal streets," not to mention regular connections to both the United States and the rest of Canada via steamer routes and the multiple railroads that existed on Vancouver Island and the mainland. ${ }^{5}$ The decision to erect new legislative buildings in 1893 only solidified the commonly held belief that Victoria was quite modern. ${ }^{6}$

As Cole Harris argues, by the end of the nineteenth century, Victoria was the "oldest, largest, and most English town in the province" while also eager to adopt modern and forward thinking ways. ${ }^{7}$ The city served, in some ways, as a bastion of Victorian ideals and order in a province that was racially diverse and still heavily-reliant on a resource-based economy with small communities scattered across both the interior and

\footnotetext{
${ }^{3}$ Patrick Dunae, "Sex, Charades and Census Records: Locating Female Sex Trade Workers in a Victorian City," Histoire Sociale/Social History, 42, 84 (November 2009), 278-279.

${ }^{4}$ John Sutton Lutz explains that the Lekwungen First Nation are "now legally known as the Songhees and Esquimalt bands, and their ancestral home is now occupied by the urban core of Victoria"; Makúk: A New History of Aboriginal-White Relations (Vancouver: UBC Press, 2008), 50.

${ }^{5}$ Alexander Begg, ed. Begg and Lynch's Hand-Book and General Guide to British Columbia, vol. 1, no. 2 (Victoria, BC: The B.C. Guide Publishing Company, 1893), 88.

${ }^{6}$ Barman, The West Beyond the West, 117.

${ }^{7}$ Cole Harris, The Resettlement of British Columbia: Essays on Colonialism and Geographical Change (Vancouver: UBC Press, 1997), 159.
} 
the coast. As the capital, Victoria was also populated by a wide range of governing men (and few women) working for the burgeoning provincial state, and who, as we shall see later in this thesis, took very seriously the goal of cultivating a modern, Victorian population for the entirety of British Columbia.

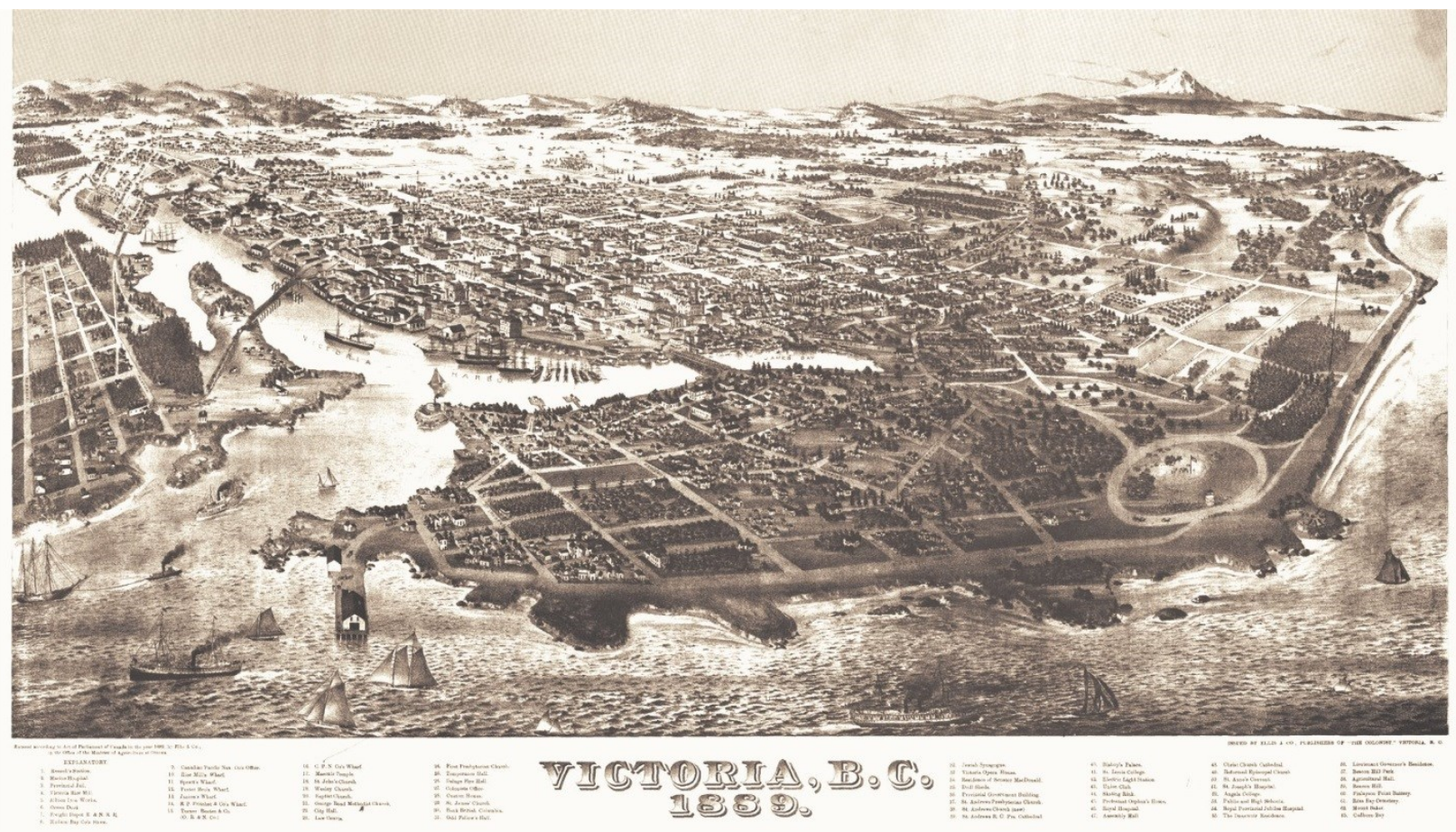

Figure 1: Birdseye View of Victoria, B.C., 1889

Source: vihistory.ca

Nineteenth-century Victoria was one of a "handful of colonial enclaves" that harboured much of the British settler population in the province, even if it "never came close to rivalling the First Nations population" that was present long before and during much of the nineteenth century. ${ }^{8}$ Though by 1901 the Indigenous population in Victoria proper had all but disappeared, and by 1911 even the Songhees Reserve had been relocated, through the 1860 s the First Nations living in and directly around Victoria

\footnotetext{
${ }^{8}$ Adele Perry, On the Edge of Empire: Gender, Race and the Making of British Columbia, 1849-1871 (Toronto: University of Toronto Press, 2001), 13.
} 
numbered in the thousands. ${ }^{9}$ This was but one aspect of the growing concern about morality and the construction of a proper Victorian society on the part of the politicians, and reformers in the city. Victoria was constructed to serve as a more permanent, settled space in what was considered an all too diverse and all too quickly shifting colonial society.

Permanence was believed to be essential for perpetuating Victorian ideals of family and community. As well, a permanently settled population was important for moral regulation and governance. ${ }^{10}$ As the capital, furthermore, Victoria was thought to stand in contrast to the rough-and-tumble, homosocial environments of resource-based interior towns. Victoria thus needed to be maintained as a morally correct and ordered city that would serve as a reminder and a model to the rest of the province of what the ideal society should look like. These ideals were disseminated to other areas of the province with the ever increasing influence of print media, the travelling judges of the court system, the public school system, and especially via settlers moving out from the city into the interior to live as farmers.

The downtown area of Victoria was situated around the Harbour and James Bay with the Songhees Reserve positioned directly across the harbour from Johnson Street and Wharf Street (See Figure 2). ${ }^{11}$ Almost directly to the north of Johnson Street was Chinatown, an area of the city that had existed since colonial times and had only grown

\footnotetext{
${ }^{9}$ John S. Lutz, Patrick A. Dunae, Jason Gilliland, Don Lafreniere, and Megan Harvey, “Turning Space Inside Out: Spatial History and Race in Victorian Victoria," in Historical GIS Research in Canada, eds. Jennifer Bonnell and Marcel Fortin (Calgary: University of Calgary Press, 2014), 5-11; John Sutton Lutz's, Makúk: A New History of Aboriginal-White Relations (Vancouver: UBC Press, 2008), 49-117 for a closer discussion of the First Nations who lived within Victoria in the nineteenth century.

${ }^{10}$ Adele Perry “'Oh I'm Just Sick of the Faces of Men': Gender Imbalance, Race, Sexuality, and Sociability in Nineteenth-Century British Columbia,” BC Studies, 105/106 (Spring/Summer 1995), 33;

Barman, The West Beyond the West, 104.

${ }^{11}$ Lutz, Makúk, 100-101.
} 
upon the completion of the CPR and the settlement of more Chinese labourers. ${ }^{12}$ These neighbourhoods and streets had definitive boundaries in the minds of Victorians and spaces were constructed by those living within and around them on the basis of race, class, and profession. ${ }^{13}$ Victoria also had a fairly well-defined moral geography. As Patrick Dunae's research on sex work in the city reveals, Broad Street (the commercial centre of the city), the Lower end of Herald and Chatham (the industrial part of the city), and Fisguard Street in Chinatown, were understood by many residents to be hubs of sexual commerce. ${ }^{14}$ While later scholars have emphasized the racialized and classed elements of this moral geography, contemporary boosters championed the "respectable" areas of Victoria as being "well laid out," including its business district where there were "numerous handsome business blocks and public buildings." $" 15$ Presumably information like this was referring to those areas of town where increasingly professional classes such as doctors and lawyers conducted business and performed their roles as proper and "regular" members of white Victorian society. ${ }^{16}$ Not only that but these classes had power within Victorian society as they were a key part of the relocation of the Songhees reserve in $1911 .^{17}$ The professional class of doctors and the social spaces of Victoria will be given a closer examination in Chapter Four of this thesis as doctors feature heavily in

\footnotetext{
${ }^{12}$ Lutz et al,. "Turning Space Inside Out," 5, 12.

${ }^{13}$ See Lutz et al., "Turning Space Inside Out," for an in-depth discussion of how GIS was used to identify and analyze racialized space in late-nineteenth century Victoria.

${ }^{14}$ Dunae, "Sex, Charades, and Census Records," 279.

${ }^{15}$ Begg, Hand-Book and General Guide to British Columbia, 88.

${ }^{16}$ As R.D. Gidney and W.P.J. Millar, Professional Gentlemen: The Professions in Nineteenth-Century Ontario (Toronto: University of Toronto Press, 1994), 3, discuss in the context of Upper Canada, there was an understanding in much of English Canadian society that the term "professional," in its most restrictive sense, referred "almost exclusively to divinity, medicine, and the law." These professionals were considered to be the pillars of society and, in Victoria particularly, would uphold proper Victorian values. ${ }^{17}$ Lutz, Makúk, 88.
} 
the discussion of the case file involving a botched abortion and subsequent death of a young woman whose doctor was charged with her murder.

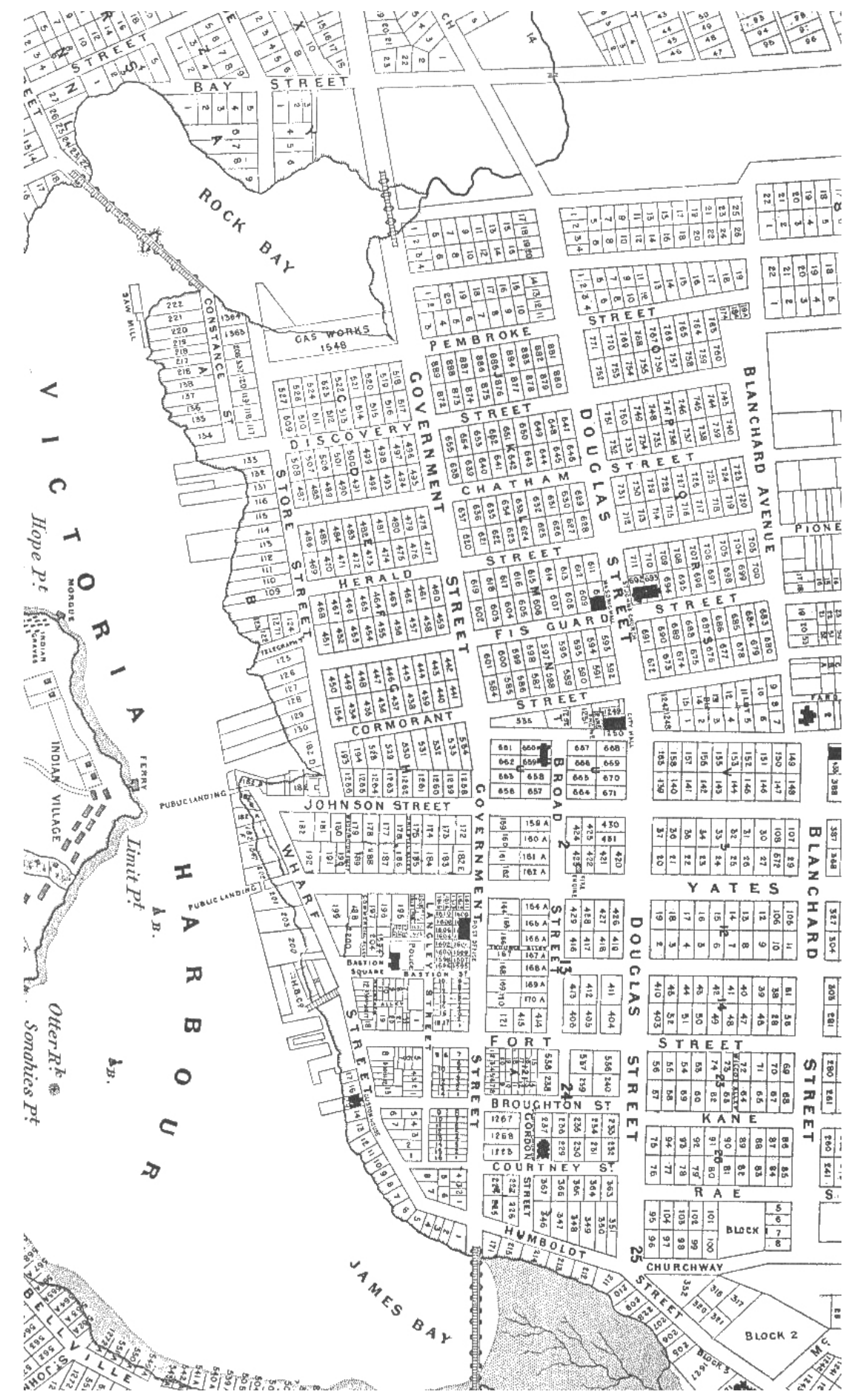

Figure 2: Downtown Victoria, B.C., 1884 - See the edge of the Songhees Reserve just across the harbour from Johnson Street.

Source: vihistory.ca. 
Despite attempts to construct and maintain the particular identity of Victoria as a strong bastion for European (white and Christian) authority and morality, there was still a large Indigenous population until the end of the 1890 s and, more obviously in contrast to the morally upright and ordered city, the presence of red light districts and prostitution. ${ }^{18}$ As the city's population more than doubled from 1881 to 1891 to almost 17, 000 people, concerns around the influx of American miners (due to the gold rushes) and the continued existence of these morally corrupt areas only grew. ${ }^{19}$ The governing classes of Victoria worried that the capital was threatened by the social evils of prostitution, a "social evil" exacerbated by the racially diverse, working class, and mainly male population. Though this was not a fear found only in or about Victoria, it was a fear that was articulated more clearly in the capital by the governing classes who resided in the city. ${ }^{20}$ In regard to prostitution and red light districts, however, Victoria, the "model" for the rest of the province, shared more in common with the burgeoning resource towns of the interior than its boosters wished.

The Kootenay area of the interior of British Columbia was (and still is) very different from Victoria geographically, economically, and even demographically. Located in the southeastern corner of the province, the towns that emerged in the last decades of the nineteenth century in the Kootenay region were resource-based "frontier" towns that, from the vantage of the capital, were less governable and somewhat unpredictable places. But even from the capital, the Kootenay’s were perceived as vital to the economic and financial interests of the province. These Kootenay towns emerged

\footnotetext{
${ }^{18}$ Mimi Ajzendstadt, "Cycles of Control: Alcohol Regulation and the Construction of Gender Role, British Columbia 1870-1925," International Journal of Canadian Studies, 11 (Spring 1995), 108.

${ }^{19}$ Barman, The West Beyond the West, 117.

${ }^{20}$ Harris, The Resettlement of British Columbia, 160.
} 
in the "main auriferous belt of British Columbia" which ran "from south-east to northwest" and was located just west of the Rocky Mountains. As such, their mines provided invaluable exports of minerals for industrial, capitalist markets. ${ }^{21}$ Though gold was the most sought after material in these mining communities, coal, ore, and silver were also present and desired (see Figure 3). ${ }^{22}$ Part of the reason for the region's differences from Victoria and the other key cities on the coast was due to the fact that the area had only really begun to feature permanent white settlement in the summer of 1890 due to this increased mining activity. ${ }^{23}$ Revelstoke in particular boomed with the arrival of the Canadian Pacific Railway and both the mining and forestry industries. Revelstoke had existed pre-1890s but it was known as Farwell and was an even smaller, single-resource town until the CPR came through. ${ }^{24}$ In the Hand-Book of British Columbia, Revelstoke was specifically described as "[o]n the C.P.R. 387 miles from Vancouver and the centre of supplies for the West Kootenay district."25

${ }^{21}$ Begg, Hand-Book and General Guide to British Columbia, 5-6.

22 Jeremy Mouat, Roaring Days: Rossland's Mines and the History of British Columbia (Vancouver: UBC Press, 1995), 5.

${ }^{23}$ Charleen P. Smith, "Boomtown Brothels in the Kootenays, 1895-1905," in People and Places: Historical Influences on Legal Culture, eds. Jonathan Swainger and Constance Backhouse (Vancouver: UBC Press, 2003),120; Mouat, Roaring Days, 12-15.

${ }^{24}$ R.P. Pettipiece, Revelstoke City Directory, 1898, vol. II (May 1898), 3.

${ }^{25}$ Begg, Hand-Book and General Guide to British Columbia, 13. 


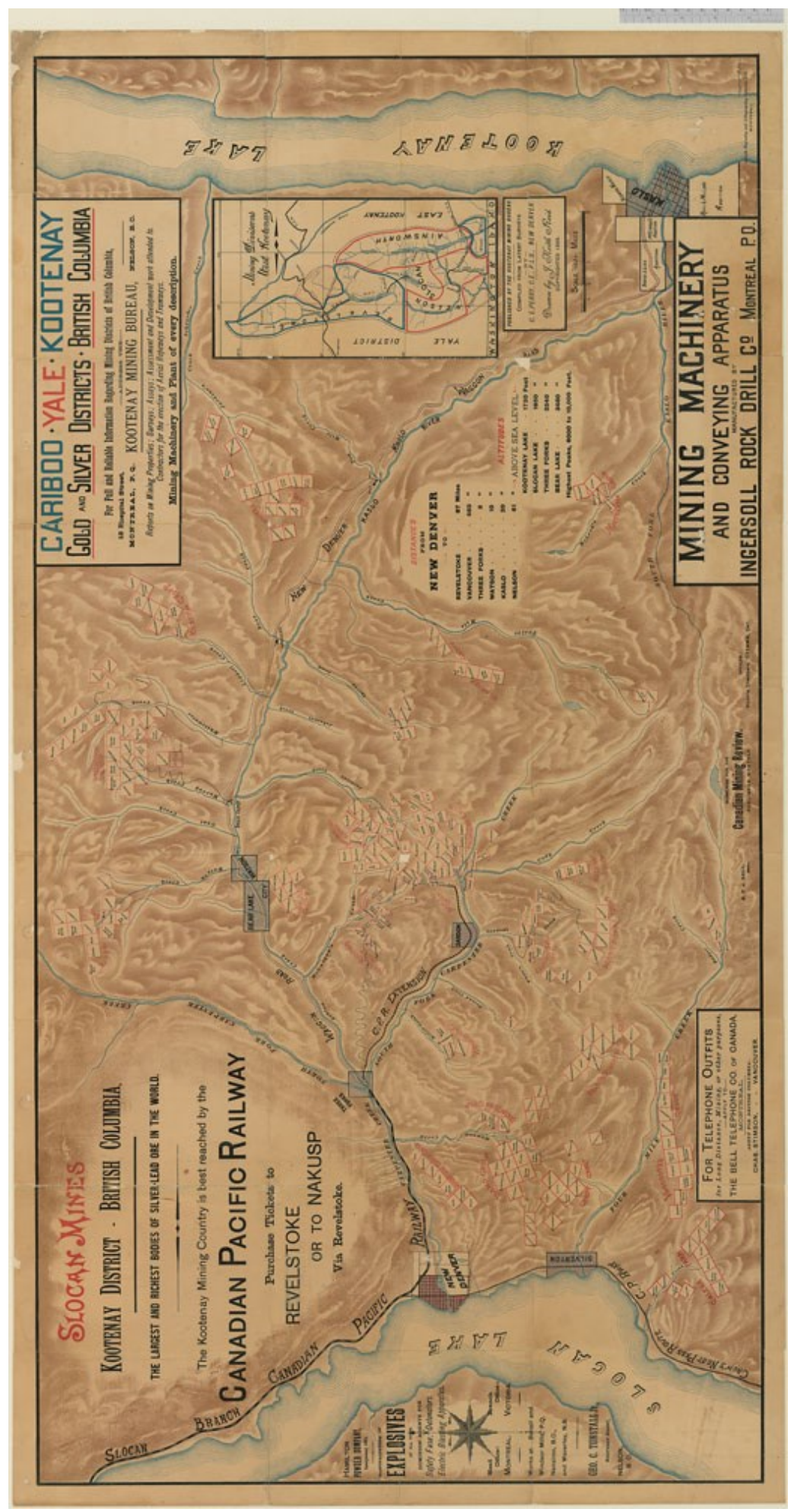

Figure 3: Slocan Mines, Kootenay District, B.C., 1895 - This map illustrates how important mining and the C.P.R. was in the Kootenays. Source: Online MIKAN no. 3851879, Kootenay Mining Bureau, collectionscanada.gc.ca. 
As a regional economic and cultural centre, Revelstoke's hotels were well-known and well-frequented social spaces. The finer hotels served as attractive meal stops for passengers who were on their way east or west, but not all hotels in Revelstoke were equal. Some were like the Union Hotel which advertised itself as the "Finest Hotel in the Kootenay" where "Everything [was] Strictly First-Class," while others like the Columbia House ("[t]he largest hotel in town, centrally located, good accommodation") were somewhat more modest. ${ }^{26}$ It was hotels like the Columbia House that served miners, loggers and prospectors on weekends away from their work camps, rather than as stops for those CPR passengers looking for a fancier meal. These hotels, plus the local brothels and pubs, were viewed as the less proper or less moral spaces of these interior towns (as they were in Victoria). Indeed, the high number of hotels in a comparatively small town like Revelstoke underlined the transient, sojourning labour that distinguished it from more-settled Victoria. At the same time, the moral geography of these resource towns also resembled the capital in some important ways.

As they existed in Victoria, so too did brothels and prostitutes exist in the majority of towns in the Kootenay region, even if distinct red light districts did not emerge until later in the nineteenth century and even into the early twentieth century. For example, the city of Rossland in the Kootenays had several brothels owned by women, some of which operated even into the early 1900s while the nearby city of Nelson had brothels operating until the 1950s. ${ }^{27}$ Similarly, in Victoria it was not until 1906 that the only growing momentum of the social purity movement really curtailed the sex trade as the "moral and economic climate of the city was already changing in ways not conducive

\footnotetext{
${ }^{26}$ Pettiepiece, Revelstoke City Directory, 27-28.

27 Smith, "Boomtown Brothels," 127-130.
} 
to the sex trade." ${ }^{28}$ In many cases the women who worked in and ran these brothels were viewed by other members of society as a necessary evil, if not entirely accepted or respected. They had enough ties to the local community to contribute to it and remain as permanent fixtures that, if nothing else, helped to appease the transient male labourers and keep them from intermixing with the Aboriginal women (still a presence in the interior), while also being generally law abiding and open to regulation through police fines. ${ }^{29}$ Intimate relations between white men and Aboriginal women were viewed by reformers, especially in the late-nineteenth century, as a worse alternative to their interactions with prostitutes, something that, given the commonly held belief of prostitutes as the social evil during the social purity movement, speaks to how deeply ingrained ideas of race were in Victorian culture. ${ }^{30}$

Even such a basic level of respect for brothel owners and sex trade workers, however, was not the case for those women who travelled from town to town selling their services and there is evidence that in many resource towns the job of new recruits in police stations was to monitor the people who came off the daily trains. If young, single women were met by a respectable member of society they were left to their own accord, however if they were met by someone disreputable or, even worse, stepped out on their own, it was the job of the officer to follow her until the nature of her business could be confirmed. In the case of a confirmation of intent to prostitute, the woman was either charged within a few days or a week or sent out of town with a warning. ${ }^{31}$ As transients,

\footnotetext{
${ }^{28}$ Dunae, "Sex, Charades, and Census Records," 286.

${ }^{29}$ Smith, "Boomtown Brothels," 137.

${ }^{30}$ See John McLaren's, "Chasing the Social Evil: Moral Fervour and the Evolution of Canada's Prostitution Laws," Canadian Journal of Law and Society, 1 (1986), 125-166 for a good in-depth discussion of prostitution as the social evil in nineteenth century Canada, particularly in regard to the regulation of it through changing laws about prostitution.

${ }^{31}$ Smith, "Boomtown Brothels," 137.
} 
these women were not viewed as having any stake in the community and as such were not acceptable and fell more specifically within the "social evil" understanding of prostitution. There was a clear division here between these constructed ideas about prostitutes as the "social evil" and concerns over their possible necessity as well as a clear break between contemporary ideas of transient men as opposed to transient women. ${ }^{32}$ The former was considered a necessary evil more often than the latter and, in the majority of cases, the latter was not to be tolerated at all.

The movement of people and the uneven efforts to place a permanent white settler population into the Kootenays and other areas of the interior were viewed from Victoria as part of the social "problem" that needed reform. Others, however, felt very differently about these mining towns. According to some contemporaries, these mining towns were “"miracles of law and order' with no gun play or anarchy but only the incorruptible figures of British Justice." ${ }^{33}$ Not only that, but Revelstoke in particular was promoted as a "thriving place," an attribute that was directly linked to the fact that it had "[t]rains east and west each day." " 34 As with Victoria there were ties between belief of success and the very physical links that the new infrastructure created with the rest of the country. The railway had brought "civilization" to the interior via its steadily growing white settler population and though it was not fully formed, they believed that they would be able to use reform through the law as a way to mould society. As with the rest of the province, it would seem that the Kootenay region had its share of contradictions. Like in Victoria,

\footnotetext{
${ }^{32}$ Dunae, "Sex, Charades, and Census Records," 285.

${ }^{33}$ Mouat, Roaring Days, 39; Mouat points out in his footnotes that the quote he includes in the text is from an article in called "Crop of Pay Ore Facts" in the Evening Telegram, 18 December 1896 (Toronto); Smith also provides a discussion of these contemporary understandings of interior mining towns in "Boomtown Brothels," 122.

${ }^{34}$ Begg, Hand-Book and General Guide to British Columbia, 13.
} 
boosters chose to ignore these, as evidenced by the bold statement in the introduction to the Revelstoke City Directory of 1898: "[i]n reading the contents of this directory you can form your own opinion as to the progress and stability of Revelstoke, the North Kootenay Capital. ${ }^{, 35}$ It would appear that the writers of the Directory believed that the answer was clear; Revelstoke was a progressive, stable and growing town that could fit the Victorian ideals of the more populated coastal towns.

The moral, social, and economic geographies of Victoria and Revelstoke were targeted by various reform movements in the late Victorian era. This was a reform movement that echoed that unfolding across cities in Canada, the United States, and Great Britain. As it was in those other areas, the reform movement in British Columbia was influenced and inspired by the "doctrine of the social gospel, Protestant ministers and social reformers" who "called for the purification of society in keeping with Christian values. ${ }^{, 36}$ These calls for reform were, in turn, linked to fears about the increasing industrialization and urbanization of society as well as other "massive demographic, social, and political changes, ${ }^{, 37}$ all of which were expected to lead to growing societal immorality, the breakdown of the heterosexual, nuclear family, and the creation of "pervasive social disorganization and crisis." ${ }^{, 38}$ Reformist energies had, of course, been directed at indigenous peoples at missions, and via the efforts of itinerant missionaries roaming the province (and before that, colony). White women were recruited into the colony to affect the "civilization" of white men in the middle decades of the nineteenth

\footnotetext{
${ }^{35}$ Pettipiece, Revelstoke City Directory, 4.

${ }^{36}$ Ajzendstadt, "Cycles of Control," 103.

${ }^{37}$ Ajzendstadt, "Cycles of Control," 110.

${ }^{38}$ Ajzendstadt, "Cycles of Control," 104.
} 
century, a project which also shared the same reformist ambitions. ${ }^{39}$ Yet the reform movement which coalesced in the late-Victorian period focussed itself more explicitly on educating and regulating residents as citizens and on trying to cultivate "healthier" moral geographies in the province's cities and towns.

Fears about the presence of immoral spaces like brothels and working-class or racially-diverse neighbourhoods continued to be a driving force behind the moral regulation and governance of British Columbian society, though broad reform movements and groups were fairly limited until the $1890 \mathrm{~s} .{ }^{40}$ Politicians and church reformers sought to regulate society with the help of "capitalist industry, a British legal system, and a highly regulated and ritualized system of civic government."41 This did not mean, however, that what was being legislated was, in fact, a hegemonic force in this society. The practical realities of enforcement by members of the society, especially the police and the courts, were not consistent. As well, much of the early British Columbian experience with the social purity movement occurred at the local level rather than through larger, institutionalized reform networks. This did begin to change in the $1890 \mathrm{~s}$ with the formation of British Columbian chapters of groups such as the Moral Reform League of Victoria and the Women's Christian Temperance Movement (WCTU) which then "initiated campaigns demanding that authorities enact legislation regulating the behaviour of individuals. ${ }^{42}$ Both in the early and later stages, however, the law was a key aspect of the reform movement. In Canada, many pillars of moral reform were

\footnotetext{
${ }^{39}$ Perry, On the Edge of Empire, 146 gives a brief discussion of the four attempts by the colonial government to cause the immigration of white, British women to British Columbia. The first attempt occurred in 1859 followed by one in 1862, a third in 1863, and the final attempt in 1870, just before confederation.

40 Ajzendstadt, "Cycles of Control," 103.

${ }^{41}$ Perry, "From 'the Hot-Bed of Vice,", 600.

${ }^{42}$ Ajzendstadt, "Cycles of Control," 104.
} 
clearly codified in the law as evidenced by the 1892 Federal Criminal Code. Title IV of the Criminal Code, for example, was "Offences against religion, morals and public convenience" which showed quite clearly the intertwining of Christian ideals, morality and the actions and experiences of the public. ${ }^{43}$

While social reform in the most westernmost province of Canada was located first in Victoria and Vancouver, reformist discourse and practices travelled the railways into the Kootenay region via newspapers, travelling judges, visitors, and new settlers. For example, federal debates in Ottawa and changing legislation surrounding the crime of seduction were just some of the stories that were included in local newspapers in the interior of British Columbia. On 22 May 1897, the Revelstoke Herald included a story about Member of Parliament John Charlton's attempts to put through a new Seduction Bill that would raise the age of consent for the female from sixteen to eighteen years. The Seduction Bill, according to the article, was also being put forward in conjunction with his Bill for Sabbath Observance. ${ }^{44}$ Yet another article almost a year later on 06 April 1898 discussed other attempts to change laws related to morality and sexuality, this time regarding a request "to dispense with corroboration evidence in such cases as criminal seduction, defilement and carnal knowledge of Indian women." Though printed in the Revelstoke Herald a small by-line showed the reader that it was an article previously published in Ottawa on 1 April $1898 .{ }^{45}$ John Charlton was himself a Member of Parliament for Norfolk North, Ontario and not associated with British Columbia or the

\footnotetext{
${ }^{43}$ Criminal Code, 1892; Amended 1893 (Montreal: Whiteford and Theoret, Law Publishers, 1894), XVII. ${ }^{44}$ Revelstoke Herald, 22 May 1897.

${ }^{45}$ Revelstoke Herald, 06 April 1898. As I discuss later, newspaper articles like these also contributed to and reflected the perpetuation of ideas of "whiteness" that were in BC always placed in opposition to constructions of Indigenous (and often Asian) identities.
} 
Kootenay region in any specific way. Yet his name and the reformist discourse he wished to see codified as law did find its way into local culture.

That the newspaper would report on Charlton's efforts to codify moral reform in the Criminal Code was hardly incidental. Charlton's Seduction Bill, for example, was intended to shield young, white women and men who might be led astray from the path they were meant to follow; appropriate courtship leading to an appropriate marriage. Later chapters will address this specific point more fully, but for now it is more important that we consider the broader politics involved with social reform and social purity becoming the basis for law. The Seduction Bill was a classic example of legislative liberalism, in that it sought to regulate people's behaviours in an effort to "protect" their freedoms.

The discourse of liberalism itself was key to the structuring of these peoples' "expectations about the law and its administration" both from a more institutional standpoint and the on the ground aspect of social practice. Liberal discourse was embedded not only in the courts themselves but also in "the way people conceived of their relationships as being managed" by them and other disciplinary powers. ${ }^{46}$ Many, if not most, white British Columbians felt that a "strong central state and the intervention of the law and the courts was necessary to aid the pursuit of individual gain. ${ }^{.47}$ There was a sense both of the individuality that was required among members of a frontier population as well as an understanding on their part that the law and state were still required to construct and maintain a standardized and "proper" society. Early forms of British Columbian law were business based as control, for nearly half a century of post-white

\footnotetext{
${ }^{46}$ Tina Loo, Making Law, Order, and Authority in British Columbia, 1821-1871 (Toronto: University of Toronto Press, 1994), 157.

${ }^{47}$ Loo, Making Law, 3-4.
} 
settlement history, involved the control of fur trading companies (namely the Hudson Bay Company) as they represented European power in the Northern Cordillera. ${ }^{48}$ The waning fur trade changed this and, with the joining of the two colonies and the subsequent entrance into Confederation, there were changes yet again. The law was "at the forefront of European colonialism in the late nineteenth and early twentieth centuries," something that can be seen clearly in the history of British Columbia. ${ }^{49}$

After 1871, British Columbia, like most British based legal systems, had a multilevel judicial system. In the early 1890s the venerable Chief Justice, Sir Matthew Baillie Begbie, continued to hold his post in the Supreme Court of British Columbia in Victoria. Directly beneath him were the "Puisine Judges" or regular members of court, H.P.P. Crease, G.A. Walkem and W.T. Drake (all of whom resided in Victoria), as well as J.F. McCreight (residing in New Westminster on the mainland). Beneath them came the members of the County court who were stationed in Nanaimo, New Westminster and Yale while Sheriffs were appointed in Victoria, New Westminster, Yale, the Cariboo, the Kootenays and Nanaimo. There was also a level of Stipendiary Magistrates posted at strategic locations throughout the interior and Vancouver Island. ${ }^{50}$ As Tina Loo argues, it was through this hierarchical legal system that contemporaries hoped to affect "a particular kind of social, political, and economic order" that would privilege "a particular set of values through both the civil and criminal law." ${ }^{, 51}$ And for reformist minded judges, especially, this order included the promotion of white, heterosexual families. This promotion fit with the shifting locus of patriarchy which, according to Jane Ursel

\footnotetext{
${ }^{48}$ Harris, The Resettlement of British Columbia, 33.

${ }^{49}$ Douglas C. Harris, Fish, Law and Colonialism: The Legal Capture of Salmon in British Columbia (Toronto: University of Toronto Press, 2001), 186.

${ }^{50}$ Begg, Hand-Book and General Guide to British Columbia, 80.

${ }^{51}$ Loo, Making Law, 3.
} 
and Chris Clarkson, had "shifted from individual household heads to legislators and judges." 52

This increasing intervention of the British Columbian judicial system was only further evidenced by cases like that of Matthew M. Pettipiece who was charged with failing to provide for his family in 1898. As the husband of Barbara Pettipiece he was under a "legal duty and bound by law to provide sufficient food clothing, and lodging and all other necessaries for Barbara Pettipiece his said wife." According to the charges laid against him he had failed in this, "neglecting and omitting without lawful excuse to provide necessaries for her" and in doing so had caused her life to be "endangered and her health [to] likely... be permanently damaged." ${ }^{53}$ He had failed in his patriarchal duty and as such there was an intervention on the part of the state and the judiciary. Strong families required strong and stable patriarchs and if they were not capable of doing the job, the state would attempt to do so for them.

Cultivating a population of strong, stable families required the promotion and protection of healthy and morally-appropriate forms of courtship, as well as "more overt regulation with respect to 'the states' interest in reproduction," something that will come to the fore more clearly in the fourth chapter as I more closely analyze the abortion case file. ${ }^{54}$ Courtship was important to the moral health espoused by Victorians as it was considered the path along which men and women travelled to reach the ultimate goal, marriage, children and a proper family. The proper family would continue along this line

\footnotetext{
${ }^{52}$ Chris Clarkson, Domestic Reforms: Political Visions and Family Regulation in British Columbia, $1862-$ 1940 (Vancouver: UBC Press, 2007), 83.

${ }^{53}$ Warrant in the First Instance, Regina v. Pettipiece, file 1898/32, box 1, GR-2355, British Columbia Archives.

${ }^{54}$ Christopher Clarkson, "Remoralizing Families? Family Regulation and State Formation in British Columbia, 1862-1940," (Unpublished PhD Dissertation, Department of History, University of Ottawa, 2002), i.
} 
and so populate society while also supporting and perpetuating the ideals most valued in that same society. Concern over the creation of these families only increased among the middle-class, white settler society during the late-nineteenth century in British Columbia as the increasing birth rates of both the working-class and racial minorities was matched by the steadily declining birth rates of the "Anglo-saxon middle-class.",55

Attempts to regulate the process of courtship and even marriage and child rearing through things like increased legislation against seduction, the Married Women's Property Act, and the Destitute Orphans act were all directed at attempts to counteract fears of (among other things) "race suicide," a swiftly shifting society and a loss of power over those felt to be beneath them and detracting from the ideal society. ${ }^{56}$ The process of courtship, it was understood by reformists, could go very wrong, even criminally so in cases where incidents of seduction, indecent assault or rape occurred. The question then became how to educate the young men and women of society about how to properly follow this path of courtship to the approved conclusion. Parents were expected to be the main role models and, through their guidance and supervision, teach their children how to court. Good courtship was also, however, taught through manuals and handbooks.

In these manuals, a proper courtship was said to involve a "number of quiet attentions, not so pointed as to alarm, nor so vague as not to be understood." Those courting were expected to "carefully" repress "all extravagance of feeling... as an offense against good breeding." Some in society, however, felt that these and many other requirements were not clear enough to young people and that some way of teaching these techniques of courtship was required. It was to serve this purpose of education that

\footnotetext{
${ }^{55}$ Ajzandstadt, "Cycles of Control," 111.

${ }^{56}$ See Clarkson, Domestic Reforms for a discussion of how families were regulated in British Columbia through particular political ideals and legislation in the nineteenth century.
} 
manuals of etiquette were introduced. These manuals tended to have full sections regarding the etiquette of both courtship and marriage specifically which made clear the opinions of the authors regarding the education of young men and women:

If our young people were taught what they ought to know - if it were told them from infancy up - if it were drilled into them and they were made to understand what now is all a mystery to them - a dark, vague, unriddled mystery - hearts would be happier, homes would be brighter, lives would be worth living and the world would be better. ${ }^{57}$

It was understood, and expressed in these manuals, that the rules of courtship should be "within reach of every household" in Canada, though it was felt that a "right love surpasses them all; and can render us all happier than our utmost imaginations can depict; and a wrong move miserable." Courtship was an important step in any young man or woman's life as it was through courtship that they would move to the aforementioned next step in life; marriage and family life. The norms and understandings of this family life as the "key element of social change" were all applied and it was felt that through guiding and teaching these young people about courtship they could regulate and govern this particular building block of society more closely to ensure the "creation of a moral and healthy Canadian nation" generally and British Columbian society specifically. ${ }^{58}$

Proper courtship began with the initial interaction on the part of the man. If the woman was a close acquaintance then it tended to be an easier switch to courtship, however, if they were fairly unacquainted it was the man who initially needed to make the key decisions. It was he who needed to determine the "position and prospects" of the lady and from this he could "judge whether or not they [were] such as would justify him in striving to win the lady's affections, and later on her hand in marriage." The lady's

\footnotetext{
${ }^{57}$ Maude C. Cooke, Social Etiquette or Manners and Customs of Polite Society (London, ON: McDermid \& Logan, 1896), 116.

${ }^{58}$ Ajzendstadt, "Cycles of Control," 109.
} 
position in this interaction was deemed "negative to a great extent," though she was required to make her preferences known by subtly accepting or declining any advances on the part of the man. This could be difficult on the part of the woman if there was a lack of knowledge on her part regarding the suitor's past life or even his present circumstances but, according to the manual, there were ways to determine these things subtly over time. ${ }^{59}$ Incidents like seduction would have inevitably arisen out of some courtships at least in part due to a possible misreading of social or behavioural cues.

Young men and women were expected to determine the character and disposition of a potential suitor mainly through observation. How they each interacted with their friends and family was key and, though men and women looked for different things in these interactions, the main concern was respect and affection. ${ }^{60}$ It was believed that a "true gentleman [would] never confine his attentions exclusively to one lady unless he [had] an intention of marriage." ${ }^{.61}$ In places like the resource towns of the British Columbian interior where white women were, until fairly late in the nineteenth century, generally absent in large numbers, it became even more important for these steps to be followed as most of the young, white men did not have many opportunities for the heteronormative and white courtship that was expected of them. Gender ratios were also unbalanced among the adult, white population. As Perry discusses briefly, these particular demographics and geographies very much affected white women's interactions both sexually and sociably. ${ }^{62}$ Courtship in British Columbia became a different

\footnotetext{
${ }^{59}$ Cooke, Social Etiquette, 120.

${ }^{60}$ Cooke, Social Etiquette, 121-122.

${ }^{61}$ Cooke, Social Etiquette, 122.

${ }^{62}$ Perry, “'Oh I'm Just Sick," 37-40 provides a good, albeit brief, discussion of white women and their experiences with sociability and sexuality in the late-nineteenth century in British Columbia. She is one of the few scholars to do so.
} 
experience than the one expected in other areas of Canada, though the process was expected to remain the same.

The language used in these manuals added to the discourse of masculinity and femininity that existed at the time as it constructed women as material possessions without agency and men as the active party in initiating and in having to contain their supposedly natural and inherent male passion for sex. Indeed the emerging ideals of a "muscular Christianity" during this time included the "hoped-for goal, with self-control to be attained through strict mental and physical discipline. ${ }^{, 63}$ Courtship was also often viewed as a competition among men wherein the woman was the "prize" that a gentleman would win at the end, something that was once again heightened in a place like the British Columbian interior where the competition for the few white women had added importance. The man was considered to be doing the woman the highest honour by asking for her hand in marriage and as such she should either show appropriate appreciation or, if refusing it, was expected to "do so in such fashion as to spare his feelings as much as possible." ${ }^{64} \mathrm{He}$, on the other hand, was expected to respect her choice and restrain his emotions, however passionate they might be.

In almost every reference, courtship was compared to nature and the "natural" tendencies while worries about lack of proper education were also prevalent. It was stressed that “[i]ntuition, our own selfhood, [was] nature's highest teacher, and infallible; and tells all, by her 'still small voice within,' whether and just wherein they [were] making love right or wrong." ${ }^{95}$ There was conflict within these ideas, however, as a

\footnotetext{
${ }^{63}$ Frank Mort, Dangerous Sexualities: Medico-Moral Politics in England since 1830 (London: Routledge, 2000), 90.

${ }^{64}$ Cooke, Social Etiquette, 124.

${ }^{65}$ Cooke, Social Etiquette, 118.
} 
dichotomy in Victorian constructions of masculinity and femininity occurred between ideas of what was natural and what was unnatural. If there was a need for young men and women to be educated about proper courtship, how was there a corresponding belief that this process was natural? This dichotomy was similar to the fears Adele Perry points out regarding the homosocial interactions between white men as well as interactions between white men and Aboriginal women during the early and mid-nineteenth century in British Columbia. There was an assumption that white, heterosexual relationships were the norm and were "natural," but in late-Victorian British Columbia there was clear evidence that this was not necessarily the case. This caused much anxiety on the part of those pushing for moral reform, namely the middle and upper classes in the Lower Mainland and in Victoria. As Perry explains it, race and gender were (and are) not inevitable or fixed categories. They are, instead, "historically constructed, not created through biology but normalized through biological discourse," meaning that concepts of nature, and what was and was not natural, were, in fact, constructed by society along with ideas of gender and sexuality ${ }^{66}$ Courtship was something that, while "natural," also had to be taught to young people as it was not necessarily occurring in British Columbian society the way European reformists concerned with the possibility of "race suicide" wanted it to. The incidents where courtship went criminally awry also served to push fears about morality and the sexuality of white women who were intended to serve as the "civilizers" of society but could also be crucial in leading to the destruction of society's proper foundation; the family.

I have argued in this chapter and the introduction to this thesis that concepts of regulation, sexuality, and governance cannot be understood without discussing the

\footnotetext{
${ }^{66}$ Perry, On the Edge of Empire, 5.
} 
interconnectedness of gender, race, and class. This brings me to the discussion of who does not take a central role in this thesis: Indigenous women and men. Gender was not only classed and sexualized but racialized as well. In late-nineteenth century British Columbia, changing discourses and legislation around the First Nations populations in the province meant not only that First Nations people tended to be viewed as absent in the "official" records by many historians (much like white women in the early years of the fur trade), but they were also being slowly physically edged further and further out of British Columbian society by this time. This was particularly apparent in Victoria where, by 1901, the indigenous population had all but vanished from the city itself while the Songhees Reserve had been relocated in 1911 from the eastern side of Victoria Harbour to just east of Esquimalt harbour, the suburb area of Victoria. ${ }^{67}$ Smallpox epidemics and lobbying by a faction within the business community of Victoria that cited "disease, drunkenness, and prostitution - all exchanges with the newcomers," as justification for "ridding the city of Aboriginal people" were all part of these changes in First Nations presence and population. ${ }^{68}$ Adele Perry also speaks to these shifting discourses using a discussion of housing reform in late-nineteenth century British Columbia to illustrate white settler attempts to assimilate and reorganize First Nations society. ${ }^{69}$ The law, as discussed, was an important tool of the colonial process.

The Canadian state generally, and the British Columbian government particularly, refused to acknowledge or recognize the legal spaces and customs of First Nations

\footnotetext{
${ }^{67}$ Lutz et al., "Turning Space Inside Out," 5.

${ }^{68}$ Lutz, Makúk, 88; Lutz also suggests looking at Jeannie L. Kanakos', "Negotiations to Relocate the Lekwungen, 1843-1911," (Unpublished MA thesis, Department of History, Simon Fraser University, 1982) for a more in depth discussion of the negotiations and discourses that led up to the relocation of the Lekwungen.

${ }^{69}$ Perry, "From 'the Hot-Bed of Vice.",
} 
societies. This was especially apparent with the banning of the potlatch in 1885 , a tradition in many areas of the Pacific Northwest "where, through the giving of gifts, titles were recognized and resource entitlements confirmed." The banning of the potlatch was one of many ways the British Columbian government attempted to legally restrict and change First Nations society. These actions created a situation whereby the main scholarly commentary about the law as it was understood or used by First Nations must then be understood from the colonial understanding. This is something Douglas C. Harris cautions about: "The danger lies in seeing the struggle only through the prism of the Canadian legal system, [where] Native legal spaces are difficult to reconstruct." Recreating and attempting to understand the experiences or technicalities of the British based legal system in British Columbia in the late-nineteenth century can be done, at least in part, using newspaper reports and court records, the tactic I use in this thesis. This is not a tactic that can be used when attempting to reconstruct the "legal spaces of the rapidly changing Native societies on the Northwest Coast in the late nineteenth and early twentieth century," however, as court and newspaper reporters were not generally present at the feasts and potlatches that were the legal spaces of many west coast First Nations groups. ${ }^{70}$ Though increasingly there is more reliance on oral histories and sources previously viewed as "unofficial" and therefore untrustworthy, it is still painstaking work to ensure that histories involving the laws of First Nations societies in British Columbia do not take for granted the overarching presence of the British based legal system that, Harris claims, has dimmed oral histories with "more than a century of colonial interference." ${ }^{71}$

\footnotetext{
${ }^{70}$ Harris, Fish, Law, and Colonialism, 5-6.

${ }^{71}$ Harris, Fish, Law, and Colonialism, 5.
} 
This idea of "colonial interference" should not be read as completing disregarding any possibility of Indigenous agency, however, as both colonial society and First Nations society and the law were changed due to contact and interaction with the other. ${ }^{72}$ In the colonial period in British Columbia there had been an ongoing "sexual commerce" between Aboriginal women and white men, particularly in interior towns but also in the dance halls of Victoria. This commerce included more emotional and meaningful interactions as well as the more matter-of-fact or even violent interactions of commerce. ${ }^{73}$

With the increasing European population and the push of the social purity movement, the First Nations of British Columbia fell into alternate discourses than those used to govern white society. The policing of Indigenous peoples differed in some ways as well, as Indian agents and missionaries took the lead in many of the late-nineteenth century projects of reform and were the key players among First Nations societies. Many of British Columbia's Indian agents had, in fact, served as missionaries previously. ${ }^{74}$ First Nations women were increasingly "othered" and sexualized in such a way that they were viewed as a detriment not only to white male sexuality but even to the proper formation of First Nations society by the white colonizers. As Jean Barman points out, "[i]ndigenous sexuality struck at the very heart of the colonial project" and as such, the interactions of Anglo-European colonizers with First Nations people, particularly First Nations women, did nothing to perpetuate the ideal Victorian society that most white British Columbians from the upper-middle class strove for. ${ }^{75}$ Though in leaving the First Nations story out of the central themes of my thesis I risk perpetuating colonial

\footnotetext{
${ }^{72}$ Harris, Fish, Law, and Colonialism, 202.

${ }^{73}$ Dunae, "Sex, Charades, and Census Records," 278.

${ }^{74}$ Perry, "From 'the Hot-Bed of Vice," 595.

${ }^{75}$ Jean Barman, "Taming Aboriginal Sexuality: Gender, Power, and Race in British Columbia, 1850-1900," BC Studies, 115/116 (Autumn/Winter 1997/98), 241.
} 
stereotypes about their absence and even beliefs that "whiteness" was, and is, the norm, they do not figure centrally in white European discourses about themselves. During this time European British Columbians were in the process of writing First Nations and mixed peoples out of their societies and out of their histories. This was part of how white colonizers constructed their ideal masculinities and femininities. It was evident in the language they used to discuss proper courtship and it was even apparent in the language of the legal documents and newspaper articles that relate to the case files I use as the assumption is always, unless stated otherwise, that those involved are white. As cited earlier, an April 1898 article in the Revelstoke Herald discussed changes to the criminal code and cited an act that related to "criminal seduction, defilement, and carnal knowledge of Indian women." Even here there was a distinct separation between the concept of seduction, and the "carnal knowledge of Indian women" which was, according to contemporary opinion, a separate legal and social matter. ${ }^{76}$ Even in the structuring of the law, there was care to differentiate Indigenous women as belonging to a different category of womanhood from non-Indigenous women. ${ }^{77}$

This was only highlighted more for me in the records consulted for this thesis. First Nations men and women do exist in the legal record and case files, however, the discourse used to describe the crimes and those involved is different from that used to describe the crimes and characters of white perpetrators and victims. The First Nations presence was almost non-existent in the seduction and abortion records consulted for this thesis, possibly in part because of the differing legal bodies in charge of governing but

\footnotetext{
${ }^{76}$ Revelstoke Herald, 06 April 1898.

${ }^{77}$ Constance Backhouse provides an important discussion of the racialization of Canadian law during the first half of the twentieth century in her work Colour-Coded: A Legal History of Racism in Canada, 19001950 (Toronto: University of Toronto Press, 1999).
} 
also due to the aforementioned and differing discourses that surrounded them. When working through the case files found with search terms such as "seduction" and "courtship," the case was always regarding members of the white British Columbian population. The few sources I read that centred on Aboriginal women or men tended to be closely associated with terms such as "prostitution" and crimes like public drunkenness. What is clear here is that the discourse around Aboriginal sexuality and social spaces of courtship differ immensely from those of the European British Columbians and though each informs the other to a large degree, I would not be able to do the subject justice within the project I have outlined here or using the legal sources consulted for this thesis. Scholars such as Cole Harris, Douglas C. Harris, and Adele Perry (among others) all make it clear that taking on the task of First Nations history, particularly reconstructing the "legal spaces" of First Nations societies in British Columbia in the late-nineteenth century, is not something to be taken on lightly.

I have argued in this chapter that the geographies of British Columbia, both moral and physical, matter when looking at concepts of moral regulation, sexuality, and governance. In this chapter I have also discussed those people who are excluded from this thesis and why. In the following chapters I will build off of the context provided here and move to a more in depth analysis of late-nineteenth century British Columbian case files that relate to the crimes of seduction and abortion leading to death. Taking place in the Kootenay region and the capital city Victoria, these incidents can be viewed in part through legal material and press reports despite the problems associated with these sources. British Columbia in the last decades of the nineteenth century served as a unique backdrop for these crimes, the people involved, and the subsequent interactions of 
these people within the legal frameworks and institutions they found themselves in. Not only that, but the moral and physical geography of Canada's westernmost province shaped how these interactions occurred and why. Morality, sexuality, gender, and governance were not static concepts and instead changed along with the discourses and ideologies of the people inhabiting the space. 


\section{Chapter Three}

Late-Victorian Era Seduction and Constructions of Gender and Sexuality

For reform-minded Victorians, "seduction" represented a moral and social danger. Young people, especially, were deemed to be in need of legal protection so as not to suffer from its most threatening elements. These understandings, as Karen Dubinsky explains, are a long way from our own popular notion of seduction, one that "conjures up images of erotic flirtation, a sexual adventure in which one party is 'in charge' but the

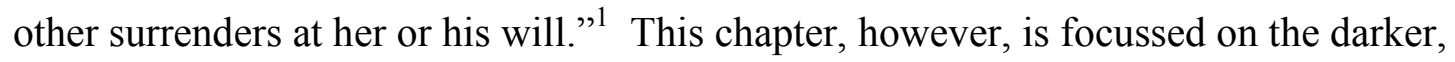
Victorian notion of "seduction" where "sexual adventure" was thought to be a threat not only to the morality of men and women as individuals, but also to the family unit and so society as a whole. As a result, in the last decades of the nineteenth century, in British Columbia as elsewhere in Canada, the criminalization of seduction became another public intervention into the intimate, private lives of citizens.

The perceived immoral and improper aspects of seduction were thought to be deviations from proper courtship, the heteronormative interaction that was expected to occur between men and women before marriage. As discussed in Chapter Two, courtship in the nineteenth century was socially regulated by particular discourses around sexuality, masculinity, and femininity. Men and women were both expected to act out particular roles through the process and at all times the repression of extravagant emotion was a key factor of proper courtship. The conclusion of the process was hopefully (but not always) marriage and children through which Victorian morals and ideals could be perpetuated

\footnotetext{
${ }^{1}$ Karen Dubinsky, “'Maidenly Girls' or 'Designing Women'? The Crime of Seduction in Turn-of-theCentury Ontario," in Gender Conflicts: New Essays in Women's History, edited by Franca Iacovetta and Mariana Valverde, Toronto: University of Toronto Press, 1992: 29.
} 
and society upheld. ${ }^{2}$ Though it was the man's prerogative to take the initial step in any courtship there was also some onus on the woman to ensure she was honest about her intentions and choices once the first step was taken on the part of said man. ${ }^{3}$ It was a fine line that these young men and women were expected to walk; in bourgeois families especially, there could be only slight deviation from the norm if any at all. These expectations, however, were paired in the late-nineteenth century with the opposing fear that not enough young men and women were being properly educated about courtship or were ignoring these lessons. ${ }^{4}$ Dangerous seduction was thus understood as the corruption or misdirection of this "normal" trajectory of courtship that was meant to occur between a man and a woman in British Columbia as elsewhere in the Victorian world. ${ }^{5}$

To make sense of how this dominant cultural sensibility translated into everyday experiences with the law, this chapter examines case files and the other related documents. Victorian concepts of consent were not firmly categorized or defined and shifting discourses could, at times, create complicated understandings of how consent, rape, and seduction differed. Though Dubinsky categorizes seduction as a "voluntary sexual activity," calling it the "'good cop' of patriarchal sexual domination," she also makes clear that the lines between rape and seduction were not always clearly drawn for Victorians. ${ }^{6}$ Seduction cases can allow for an interesting way to get at the aforementioned dynamics of gender, power, and sexuality as well as how at times definitions of consent and ideas about the letter of the law affected these. Though it definitely does not, to

\footnotetext{
${ }^{2}$ Maude C. Cooke, Social Etiquette or Manners and Customs of Polite Society (London, ON: McDermid \& Logan, 1896), 116.

${ }^{3}$ Cooke, Social Etiquette, 121.

${ }^{4}$ Cooke, Social Etiquette, 116.

${ }^{5}$ Peter Ward, Courtship, Love, and Marriage in Nineteenth-Century English Canada (Montreal and Kingston: McGill-Queens University Press, 1990), 3.

${ }^{6}$ Karen Dubinsky, Improper Advances: Rape and Heterosexual Conflict in Ontario, 1880-1929 (Chicago: University of Chicago Press, 1993), 8.
} 
modern readers, hold the same connotations as rape, the incidence of seduction creates an interesting and shifting middle ground between rape and consensual sexual relations as they fit into "normal" Victorian courtship.

This chapter examines multiple seduction cases that illustrate these dynamics. In August of 1895 Robert Blythe, an American man who had moved to Victoria, British Columbia was charged with the abduction of Belle Rockwood (also an American). The charge was later dropped to the lesser one of seduction and, though the key concerns were about jurisdiction and the technicalities of Belle's "possession" by her father, the underlying concern of sexuality and seduction was still apparent. ${ }^{7}$ Also in Victoria was the 1899 case of Regina v. Armour. James Armour was charged with the seduction of a girl who was a "deaf and dumb mute." In this situation the gendered power and concerns over sexuality and masculinity came to the fore in a lecture given by the presiding judge to the court after the verdict was given. ${ }^{8}$ In 1897 , in the small Kootenay town of Revelstoke, a man named Robert Fleming was charged with the seduction of Annie L. Young a fifteen-year-old "girl of previous chaste character." Though in the end the charges were dropped, the testimony given by Annie was telling in regards to both the social spaces of courtship (or seduction) and the understandings of contemporary ideas about masculinity and femininity. ${ }^{9} 1899$ saw another seduction charge in the Kootenays, this time involving a Mr. Thomas McRae who was charged with seducing Mable Sweet. In this case a promise of marriage was involved and Mable's guardian, David Woolsey, made the complaint. According to the courts, Woolsey had "just cause to suspect and

\footnotetext{
${ }^{7}$ Victoria Daily Colonist, 27 August 1895.

${ }^{8}$ Victoria Daily Colonist, 04 October 1899; Victoria Daily Colonist, 19 October 1899; Victoria Daily Colonist, 24 October 1899.

${ }^{9}$ Regina v. Fleming, file 1897/8, box 1, GR-2355, British Columbia Archives.
} 
believe that, Thomas McRae late of Donald, did seduce the said Mable Sweet under promises of Marriage." ${ }^{10}$ Another case involving a promise of marriage also occurred in the Kootenay district in 1898, this one concerning the assumed misdeeds of Alfred Johnson. ${ }^{11}$ Charged with the seduction of a young Finnish girl, Johnson's case was especially concerning due to the result of the alleged seduction; an illegitimate child. The case was discharged due to a lack of corroborative evidence regarding both the age of the girl and the marriage proposal. ${ }^{12}$ Though these cases occurred in very particular environments and geographies (both physical and moral) they also occurred in a broader political context as new seduction legislation at the federal level emerged. It is to these politics where we will begin.

\section{The Legal Politics of Seduction}

In Canada, the first major piece of legislation regarding seduction, "An Act to make the remedy in cases of Seduction more effectual, and to render the Fathers of illegitimate Children liable for their support," was passed on 04 March 1837. The tort evolved from an old common law rule that gave an employer or master the ability to sue over injury to his or her servant as a way to gain monetary compensation for damages or services lost. This early incarnation of the tort of seduction parallels the discussions of property and possession that emerged in its later uses. As masters saw servants as property, so too did most fathers of the time see their daughters. If that property was

\footnotetext{
${ }^{10}$ Regina v. McRae, file 1898/28, box 1, GR-2355, British Columbia Archives.

${ }^{11}$ Though Alfred's name appears as both "Johnson" and "Johnston" I have chosen to use Johnson as it is the version that appears most regularly in the sources.

${ }^{12}$ Tribune, 16 April 1898.
} 
damaged, compensation in some form was expected. ${ }^{13}$ The Act was generally supported in the legal community and its purpose was to address the failure of the current law to afford "redress to Parents whose Daughters have been Seduced; And whereas, the Law makes no provision in this Province for compelling the Fathers of illegitimate Children to contribute to their support." 14 The concern was that the parents of the victim had the option of suing for some amount of compensation. Again, society very much viewed daughters as the property of their father, something that emerged in the very language of the act as well as the fact that the seduced woman was not herself allowed to sue for damages (something that did not change even in the late 1800s with the criminalization of seduction). ${ }^{15}$ It was only the father, or if the father had died, the mother of "any unmarried female who may be Seduced after the passing of this Act" that was able to make a charge of seduction.

As the women who had been seduced in these situations were not legally able to bring their own cases to trial, compensation usually went directly to the family. ${ }^{16}$ This was especially injurious for women who became pregnant as they suffered both social shame and economic hardship as a result. ${ }^{17}$ The understanding of many in the legal profession and society at the time was that seduction cases were merely "legal fictions" and that the legislation was put in place simply (as mentioned above) to fulfill a specific

\footnotetext{
${ }^{13}$ Monica Burke, “"Creatures Devoid of Sense and Will': The Canadian Crime of Seduction and Its Early Victims," (Unpublished MA Thesis, Department of Law, Carleton University, 2001), 55.

14 "An Act to make the remedy in cases of Seduction more effectual, and to render the Fathers of illegitimate Children liable for their support," Statutes, of His Majesty's Province of Upper Canada, Passed in the First Session of the Thirteenth Provincial Parliament of Upper Canada, Chap. VIII. $7^{\text {th }}$ William IV A.D. 1837, First Session (Passed 04 March, 1837), 34-35; Emphasis in original.

${ }^{15}$ Burke, "Creatures Devoid of Sense and Will," 59-60 provides a good discussion of these "elements of power" and how contemporaries felt about whom exactly was able to bring a charge seduction against a man.

16 "An Act to make the remedy in cases of Seduction," Statutes of His Majesty's Province of Upper Canada, 34 .

${ }^{17}$ Dubinsky, Improper Advances, 15.
} 
need for familial compensation. The families of the seduced women were then able to go to court for the opportunity to gain back some monetary compensation and, just as importantly for some, the honour of the woman and her family. ${ }^{18}$ Honour was regained, at least partially, by making sure the blame was placed squarely on the man. For the most part, these "legal fictions" were understood as the family's way of attempting to gain from negative, but not necessarily tragic, situations. ${ }^{19}$ Seduction cases in the early years of this law, however, showed a "dichotomy between the strict morality of the judges and the more relaxed standards of the settlers." For many of the popular class "seduction" and premarital sex were simply facts of life and a realistic and expected part of courtship. ${ }^{20}$ It tended to be the members of the middle and upper classes that worried most about its impact on the moral health of individuals and society. These concerns became even more prominent from the mid- to late-1800s as governing bodies and populations worked to regulate what they viewed as the increasing immorality of the masses.

In the burgeoning social reform movements of the late-1870s and early-1880s, seduction once again became a hotly debated subject in the Canadian legal community. ${ }^{21}$ John Charlton, a member of Parliament for Norfolk North, Ontario for more than three decades as well as a fervent reformist and member of the Presbyterian church, was a key political actor in the growing concerns about seduction legislation. In February of 1882, Charlton put forward a bill in Parliament that allowed for the punishment of seduction through criminal law rather than just civil. This attempt to criminalize seduction met

\footnotetext{
${ }^{18}$ Ward, Courtship, 33-34.

${ }^{19}$ Patrick Brode, Courted and Abandoned: Seduction in Canadian Law (Toronto: University of Toronto Press, 2002), 11.

${ }^{20}$ Brode, Courted and Abandoned, 26.

${ }^{21}$ Dubinsky, Improper Advances, 5.
} 
with much hostility due to concerns about "designing women," and it was not until 1886 that a revised version of this bill was codified as law and "introduced the concept of seduction - as opposed to forcible, coercive attack - into Canadian law." ${ }^{22}$ Though many in the House of Commons did support the bill, they were hesitant; in the 1886 Senate debates, for example, Senator Almon stated that he was "in favour of the bill, to a certain extent, but very much opposed to some of its clauses." ${ }^{23}$

There were many amendments to this bill throughout the 1880s and 1890s with concern focussed on the age of women involved in seduction cases (Charlton's bill looked to increase the age limit of those women the bill was aimed at), as well as their "chaste character" and the lure of proposed marriage on the part of the seducer. Here Charlton was mainly concerned with protecting those women he viewed as innocent victims. ${ }^{24}$ Senator Vidal, also participating in the 1886 Senate debates, stated that there was a "lapse in [the] law between the age of twelve and fourteen." The ensuing discussion expanded on these concerns as others expressed worry over the ages included in the bill and the ways in which the wording of it could be misconstrued. ${ }^{25}$ Related to these concerns about age, there was also fear that the law would be abused by the immoral "designing woman." Consider, for example, how an author for The Legal News framed the question: "[s]hall the safeguards of female purity be removed and the descent into vice be rewarded and encouraged from mere sentimental creations?" His use of the term "sentimental creations" was a reference to the alternate stereotype of women that

\footnotetext{
${ }^{22}$ Direct quote from Dubinsky, “"Maidenly Girls' or 'Designing Women'?” 34; McLaren, "Chasing the Social Evil," 131.

${ }^{23}$ Hon. Mr. Almon, "Seduction Bill," in Debates of the Senate of the Dominion of Canada, Fourth SessionFifth Parliament (Ottawa: Holland Brothers, 1886), 468.

${ }^{24}$ Dubinsky, “"Maidenly Girls' or 'Designing Women'?" 34-35.

${ }^{25}$ Hon. Mr. Vidal, "Seduction Bill," in Debates of the Senate of the Dominion of Canada, Fourth SessionFifth Parliament (Ottawa: Holland Brothers, 1886), 468.
} 
existed at the time, that of an innocent and naïve girl (not a woman at all) who, in this author's view at least, was a fantasy and a creation. ${ }^{26}$ One Member of Parliament believed that "the age of sixteen [was] probably exceeding the proper age" and thought "if [the bill] were made up to fourteen it would be better." 27 These understandings of women and girls played an important role in the construction of the legal discourse of seduction, particularly in the courtroom.

In many seduction cases, the testimony of either the father or victim made it apparent that there had been a promise of marriage on the part of the man and that this promise was the only reason that the woman had "yielded her virtue." 28 This accusation of a marriage promise was intended to shift the "blame for the illicit intercourse onto the seducer" while simultaneously relieving the seduced girl of her "share of the infamy."29 This shifting of blame was, especially in the early 1840 s and $1850 \mathrm{~s}$, an understood and accepted aspect of seduction cases and simply part of the "legal fiction" that was being created. It was about regaining the honour of the woman and her family as well as creating an image of a naïve and innocent maiden who needed protection. This served a clear purpose for the family and also perpetuated the archetypal constructions of women as either manipulative or innocent, a process that simultaneously constructed some women's bodies as gendered victims without agency and other women as active participants in society's moral decline. Though different, both archetypes were

\footnotetext{
26 “The Seduction Bill,” The Legal News, Vol. VII, No. 11 (15 March 1884), 82. The Legal News was one of several active legal periodicals in this era. For more details see Joanie Schwartz, "The Criminal Code and the English Media in $19^{\text {th }}$ Century Canada" (Unpublished MA Thesis, Department of Criminology, University of Ottawa, 1993).

${ }^{27}$ Hon. Mr. McInnes, "Seduction Bill," in Debates of the Senate of the Dominion of Canada, Fourth Session-Fifth Parliament (Ottawa: Holland Brothers, 1886), 468.

${ }^{28}$ Brode, Courted and Abandoned, 17; see Regina v. McRae and Tribune, 16 April 1898 for examples of this in the case files under discussion.

${ }^{29}$ Brode, Courted and Abandoned, 17-18.
} 
predicated on the embodied sexuality of women: one whose body was a weapon of immorality, the other an unfortunate victim or "fallen angel."

This tactic of shifting blame was not, however, supported or agreed upon by all judges and lawyers. In later decades, as Dubinsky argues, there could be more lenient views of women in the court room when judges made it clear that not all evidence was "within the bounds of propriety." ${ }^{30}$ Whatever the prevailing habits, however, both of these archetypes were almost always present and could be deployed by anyone when needed. Both archetypes evoked fear, though in different ways. The manipulative and designing woman was feared for her ability to persuade and trick innocent men with her sexuality. The naïve and innocent girl was viewed alternately as the one who needed to be protected. The fear of the former stereotype was what led some members of society to fight those, like Charlton, who urged the criminalization of seduction. Charlton took action due to what legal historian John McLaren identifies as the "rescue impulse," the masculinist urge to "rescue" women who had simply been tricked or misled. The seduction law would, Charlton believed, give these poor innocents and their families a chance to punish the man who had taken liberties. Though McLaren most specifically discusses this "rescue impulse" in relation to how reform groups interacted with prostitutes and prostitution, the drive to help can also be applied to those who were working to protect seduction victims. ${ }^{31}$

Charlton's bill and beliefs were not always supported, and those who feared manipulative women also made their voices heard. During the same debate that discussed the age limits in the bill, the Hon. Mr. Poirier stated that in his "opinion the

\footnotetext{
${ }^{30}$ Dubinsky, Improper Advances, 28.

${ }^{31}$ McLaren, "Chasing the Social Evil," 133.
} 
word 'attempt' ought to disappear from [the] clause." He feared that if it was "allowed to stand it [would] offer inducements to girls to levy blackmail.” Mr. Poirier continued:

If an attempt is made upon a girl it can be proved by medical testimony, but an attempt to seduce would enable a girl, intent on blackmailing, and having circumstancial evidence in support of her charge, to make out a case, and it will be delivering honest men bound hand and foot to blackmailers. ${ }^{32}$

His concerns echoed others in both the government and the legal community who continued to perpetuate the construction of the devious, blackmailing women who would take advantage of Charlton's bill.

An 1884 article in The Legal Times discussed the particular clause of Charlton's bill that pertained to the idea of the "promise of marriage" as a justification women used for allowing themselves to be seduced by a man. The clause in question stated that "[a]ny person who shall under promise of marriage seduce any unmarried female of previously chaste character and not more than 21 years of age, shall be guilty of a misdemeanour, and shall be punished as hereinafter provided." This clause was of concern upon the very first introduction of the bill and, after members of parliament made this clear, it was modified in an attempt to gain more firm support. However, it was subsequently restored to the law while it was in committee, and its return garnered even more anger and hostility from members of parliament and the legal community. While the author in The Legal Times used the journal as a forum for his opinions on the matter while also insisting he was not the only one to have these views. ${ }^{33}$ The author's first attack regarding the promise of marriage clause stated that it was "suggested by an

\footnotetext{
${ }^{32}$ Hon. Mr. Poirier, "Seduction Bill," in Debates of the Senate of the Dominion of Canada, Fourth SessionFifth Parliament (Ottawa: Holland Brothers, 1886), 472; The spelling of the word "circumstantial" is as it was found in the debates.

${ }^{33}$ The author makes it clear that "many eminent judges" in Canada had written in anger to the legislature explaining their opposition to the bill. The author declares that all in opposition must now wait for the senate to "give the measure its quietus," something he clearly feels is a given, "The Seduction Bill," The Legal News, 82.
} 
erroneous view of morality" and "[w]hen a woman barters her virtue for a promise of marriage she has already ceased to be [of] a "chaste character."” The author continued that, if a girl simply gave in to the "first temptation" then the public might "sympathize with her fall, and...may condemn the seducer" but that the involvement of the law was where the trouble lay. The law should not "under any circumstances...come to her aid" or "enable her to extort the fulfillment of a corrupt contract."

The dispute can one again be tied back to the archetype of the innocent and naïve woman versus the manipulative designer woman. The author fell into the latter camp, making it clear that women (he would seem to suggest in most if not all seduction cases) were just as, if not more so, at fault than men. After all, what innocent or chaste woman would so easily give up her virtue for a simple promise of marriage? What innocent woman would think to manipulate such a situation to her benefit? The Hon. Mr. Ogilvie made his answer to such questions apparent in the senate debates: "A virtuous woman as a rule can protect her own honor, and when trouble does take place it is very questionable in my mind if the woman is not more to blame than her seducer." ${ }^{35}$ What is clear here is that some in the legal profession still felt that much of the onus should be on the woman herself, though men were still held accountable for their behaviour and character, "standards of appropriate behaviour and reputation were applied more often and more harshly to women." ${ }^{36}$ This very present fear of manipulative or scheming women using the seduction law for their own gain and, in the process, hurting innocent and morally

\footnotetext{
34 “The Seduction Bill," The Legal News, 81.

${ }^{35}$ Hon. Mr. Ogilvie, "Seduction Bill," in Debates of the Senate of the Dominion of Canada, Fourth Session-Fifth Parliament (Ottawa: Holland Brothers, 1886), 368.

${ }^{36}$ Dubinsky, Improper Advances, 24.
} 
upright men, was a very common one during this time that tended to support the push for "female" accountability during trials.

These ideas of innocence and morality were, in the late-nineteenth century, becoming increasingly tied to the age of the women, or girls, involved in these situations. Age, at the beginning of the nineteenth century, "gave no right to special treatment and children [in England and elsewhere] were tried with the full publicity and formality of judge and jury or magistrate." It wasn't until the mid-nineteenth century that "perceptions of social investigators had resulted in new distinctions between the child and the adult." 37 This was tied to the broader societal concerns "about the moral dangers of the 'modern world.",38 Archetypes of innocent maidens or designing women were intertwined with these changing concepts of age and what it meant to be a child and, once one was no longer considered a child, what that meant for a person's sexuality or morality. Governance, regulation, and education were required to keep these innocent children on the right, moral track in an increasingly turbulent and immoral society.

Another issue stemming from this move to codify the seduction bill in criminal law was the worry over "parading immoral conduct before the public." It was believed by many in Canada that the exposure of details regarding these seduction cases should be kept to a minimum. ${ }^{39}$ Chief Justice William Henry Draper of Upper Canada, for example, feared "that public airing of this unseemly evidence would incite prurient interests and provoke more sexual misbehavior in the future."40 Draper's concerns

\footnotetext{
${ }^{37}$ Margaret May, "Innocence and Experience: The Evolution of the Concept of Juvenile Delinquency in Mid-Nineteenth Century," Victorian Studies, 17, 1 (September 1973), 9, 29.

${ }^{38}$ John McLaren, "Chasing the Social Evil: Moral Fervour and the Evolution of Canada's Prostitution Laws," Canadian Journal of Law and Society, 1 (1986), 126.

${ }^{39}$ Brode, Courted and Abandoned, 28.

${ }^{40}$ Constance Backhouse, "The Tort of Seduction: Fathers and Daughters in Nineteenth Century Canada," The Dalhousie Law Journal, 10 (1986), 71.
} 
echoed those coming from England at the same time. Social purists there, for example, "opposed fresh legislation, or greater public discussion, on the grounds that this would only draw attention to sex and incite immorality." ${ }^{41}$ Politicians were concerned that during these debates over the possible changes to the criminal law, the very act of speaking about sex explicitly was corrupting. What occurred, then, was a censorship that only allowed the creation of an "apparatus" for "producing an even greater quantity of discourse about sex, capable of functioning and taking effect in its very economy." ${ }^{, 42}$

According to Michel Foucault, Victorian discourses about sexuality were rendered "morally acceptable and technically useful." ${ }^{43}$ He speaks of the attempt by people to "gain mastery" over the discussion of sexuality in "reality" and that to do so it was "necessary to [first] subjugate it at the level of language, control its free circulation in speech, expunge it from the things that were said, and extinguish the words that rendered it too visibly present." ${ }^{44}$ Attempts to control language, and through the language the act of sex itself, are clear even in the simple terms used in the law to reference this piece of legislation. In the Seduction Act sexual intercourse was described as an, "illicit connection with any girl of previously chaste character." 45 The act of sex was not explicitly stated as we might expect it to be if discussed in a law today but the very term "illicit" gives the modern reader a clear picture of prevalent feelings towards

\footnotetext{
${ }^{41}$ This quotation is from Frank Mort, Dangerous Sexualities: Medico-Moral Politics in England since 1830 (London: Routledge, 2000), 89-90; Dubinsky's Improper Advances and McLaren's "Chasing the Social," both have good discussions of social purity movements while Mariana Valverde's, Age of Light, Soap and Water: Moral Reform in English Canada, 1885-1925 (Toronto: University of Toronto Press, 1991; reprint 2008 ) is a particularly in depth discussion of social purity and moral reform in Canada during the latenineteenth and early-twentieth century.

${ }^{42}$ Michel Foucault, The History of Sexuality: An Introduction, Volume 1, trans. Robert Hurley (New York: Vintage Books, 1990), 23.

${ }^{43}$ Foucault, The History of Sexuality, 21.

${ }^{44}$ Foucault, The History of Sexuality, 17.

45 "The Seduction Act," The Legal News (19 June 1886), 194.
} 
sex and sexuality at the time. There was a distinct connotation of secrecy and of doing something one should not be doing. This negative connotation was especially true when the situation involved a girl of a young age, generally considered to be "of previously chaste character." 46 Here again we can see the archetype of the innocent girl, naïve and young and simply overpowered by both the physical and mental power of the more virile and passionate man. ${ }^{47}$

So though the act of sex itself was not explicitly described in the law or otherwise, the common understanding held by many people meant that the meaning of terms such as "illicit connection" was quite clear. Foucault described it well when he stated that "[a]reas were thus established, if not of utter silence, at least of tact and discretion" and "[a]t the level of discourses concerning sex in the field of exercise of power itself: an institutional incitement to speak about it, and to do so more and more; a determination on the part of the agencies of power to hear it spoken about, and to cause it to speak through explicit articulation and endlessly accumulated detail." 48 The language and discussions around specific seduction cases can be used to help understand how exactly these specific discourses around seduction and sexuality were created and, through this, the continued creation of a specific social structure. There were also those at the time (specifically those taking part in the social purity movements) who felt that seduction cases like these

\footnotetext{
${ }^{46}$ Dubinsky includes a good discussion of this in her book, Improper Advances (p.23) where she speaks to the fact that young girls tended to get the benefit of the doubt in cases of rape or assault as opposed to adult women who were held to be more accountable for their actions. Adult women also tended to be understood more often as fitting the manipulative stereotype as opposed to the innocent young girl.

${ }^{47}$ William Acton's book The Functions and Disorders of the Reproductive Organs in Childhood, Youth, Adult Age, and Advanced Life: Considered in Their Physiological, Social and Moral Relations (1857) can, as discussed in Chapter One of this thesis, be used to look at contemporary ideas about the belief that men's sexuality was a given and though a gentleman was expected to control it there were, at times, uncontrollable urges and passions that could not be helped. This is, again, set up in opposition to the archetype of the asexual and innocent woman.

${ }^{48}$ Foucault, The History of Sexuality, 18; Emphasis in original.
} 
could be used to educate the public and that speaking of them was required to ensure society was formed in a way that was considered morally correct. ${ }^{49}$

Part of this discourse was the aforementioned creation and perpetuation of the stereotypical "female" archetypes. Whether in Ontario, England, or British Columbia there existed two main stereotypes of women. There was also, however, a supporting cast of other stereotypes that tended to be more nuanced though still grounded in very particular discourses about women. There were many of these including but not limited to the good mother, the bad mother, and the nervous woman. ${ }^{50}$ These were all shaped and perpetuated by the different experiences and issues of the day and each archetype could be used (whether by a woman herself or those in society) to different purposes when navigating social morals and understandings. The fear of many was that the seduction bill Charlton was putting forward would negatively impact society by benefiting these women in particular. The case of a thirteen-year-old girl who claimed rape was cited in an 1884 article in The Legal News as an example of this type of woman. It became apparent during this particular trial that the girl had only thought to charge the man with seduction as an afterthought in an attempt to gain some economic advantage. The author writes that "such girls ripen fast in profligacy, and they would have ample time before the age of 21 to entrap a victim with the convenient aid of the Seduction Act. It might possibly be difficult to prove the previous unchastity, yet in reality they are as the woman 'whose lips drop as an honeycomb and whose mouth is smoother than oil.,",51 The language used in this discussion and the tone of the author makes it clear to the

\footnotetext{
${ }^{49}$ Mort, Dangerous Sexualities, 89-90.

${ }^{50}$ Carol Smart, "Disruptive Bodies and Unruly Sex: The Regulation of Reproduction and Sexuality in the Nineteenth Century," in Regulating Womanhood: Historical Essays on Marriage, Motherhood, and Sexuality, ed Carol Smart (London: Routledge, 1992), 29.

51 “The Seduction Bill," The Legal News, 81-82.
} 
reader that it is almost irrelevant whether the story is true or not. The story illustrates the fear these men feel that the law will be turned to improper use.

In Courted and Abandoned, Patrick Brode argues that it was

"technically...irrelevant whether or not the seduced person was pure" but that the "very nature of the seduction action was so based on notions of family honour that the character of the victim inevitably became a factor in the award of damage." ${ }^{\circ 2}$ Where Brode does not concern himself as clearly, however, is in the required and almost simultaneous discussion of masculinity that often occurred in these cases. In the next section of this chapter, we shall see that the character of the woman very much came into play no matter what the charge was, but so too did the (dis)honour and character of the man charged with seduction. ${ }^{53}$ Changing notions of masculinity and femininity were tied together and need to be understood in such a way. The dynamic relationships between the victim and the seducer and even the reformers, lawyers and judges who in many cases held a "dramatic and paternal vision" of the seduced victims, were all interrelated whether in eastern Canada or British Columbia. ${ }^{54}$ The character of those involved, then, can and must come into account when participating in this discussion.

\section{Gendered Identities on Trial}

Though the cases under discussion vary in location, the people involved, and even their outcomes, they all had some commonalities. Most importantly, all of these seduction trials perpetuated specific female and male stereotypes as they intertwined with a particular type of morality, a morality that society was expected to adhere to. In all of

\footnotetext{
${ }^{52}$ Brode, Courted and Abandoned, 59.

${ }^{53}$ Dubinsky, Improper Advances, 24.

${ }^{54}$ Dubinsky, ““Maidenly Girls' or 'Designing Women'?” 32.
} 
these cases the crime of seduction was key and though on the surface they may have seemed to be straightforward, there is much that can be learned by more closely analyzing the language and discourses used in the legal and journalistic discussions that occurred as testimonies were taken, cases were sent to trial, and press stories were released.

In the 1897 case of Regina v. Fleming the victim, Annie L. Young, met with Robert Fleming multiple times after their first meeting at the Presbyterian Church in Revelstoke where she was introduced to him in the company of her younger brother. Most of these meetings involved going on "drives," though Annie claimed that she did "not know how many times [she] drove with him.." held by the court, that of Annie L. Young's character and age, was brought to attention almost immediately. She was claimed to be "a girl of previous chaste character" and was "fifteen years and four months" old. ${ }^{56}$

As discussed earlier, age was important for those who had written the law regarding seduction. Section 181 of the 1892 Criminal Code stated that, legally, "[e]very one is guilty of an indictable offence and liable to two years imprisonment who seduces or has illicit connection with any girl of previously chaste character, of or above the age of fourteen years and under the age of sixteen years." ${ }^{57}$ It was also specified in Section 182 of the Criminal Code that "[e]very one, above the age of twenty-one years, is guilty of an indictable offence and liable to two years imprisonment who, under promise of marriage, seduces and has illicit connection with any unmarried female of previously

\footnotetext{
${ }^{55}$ Testimony of Annie Laura Young, Regina v. Fleming, file 1897/8, box 1, GR-2355, British Columbia Archives.

${ }^{56}$ Warrant in the First Instance, Regina v. Fleming, file 1897/8, box 1, GR-2355, British Columbia Archives.

${ }^{57}$ Criminal Code, 1892; Amended 1893, Section 181, 107; Emphasis in original.
} 
chaste character under twenty-one years of age." ${ }^{, 58}$ An 1898 amendment to the Criminal Code was put forward to "make more effectual provision for the punishment of seduction and abduction" by raising the ages of those "females" who were at risk of seduction from sixteen to eighteen in Section 181 and lowering the legal age of "seducers" from twentyone to eighteen in Section 182. ${ }^{59}$ This concern for those of a young age was not new in society; however, as previously discussed, concern had only increased in the latenineteenth and early-twentieth century as people began to worry about the corruption of the young who were understood to be the future of society and generally innocent when it came to sexuality. ${ }^{60}$ In the case of Annie Young, she fell within the age limit specified in Section 181 and was viewed with more leniency as a young girl than might have been the case if she was older. ${ }^{61}$

Age, therefore, was also a factor in discussions of Annie's "previous chaste character," yet another determination that would have helped to sway the court in her favour. The previous chastity of a seduced woman was a key turning point in any seduction trial and "the burden [was] on the prosecution to prove...that the girl [was] of good repute." ${ }^{\prime 62}$ Though this question of previous moral chastity was such a key part of the law it was also one of contention and, as previously mentioned, multiple judges and lawyers made their opposition to the clause relating to previous moral chastity in the seduction bill eminently clear. ${ }^{63}$ In the case of Annie Young her age and her "previous chaste character" combined to allow her to remain in the role of the innocent victim.

\footnotetext{
${ }^{58}$ Criminal Code, 1892; Amended 1893, Section 182, 108; Emphasis in original.

${ }^{59} \mathrm{Mr}$. Charlton, "An Act to amend the Criminal Code, 1892, so as to make more effectual provision for the punishment of seduction and abduction," $3^{\text {rd }}$ Session, $8^{\text {th }}$ Parliament (Ottawa: First Reading 8 February, 1898).

${ }^{60}$ Dubinsky, Improper Advances, 57; May, “Innocence and Experience,” 29.

${ }^{61}$ Dubinsky, Improper Advances, 24.

${ }^{62}$ Criminal Code, 1892; Amended 1893, Section 181 (4), 107.

63 "The Seduction Bill," The Legal News, 82.
} 
This occurred despite her testimony that "nothing improper [had] happened," that Mr. Fleming had not treated her "indecently" and that he had, in fact, treated her "like a gentleman [should]. ${ }^{364}$ As Constance Backhouse makes clear, and this evidence would also suggest, the seduced woman's "consent to sexual relations was irrelevant." Regardless of how Annie Young felt, the charge of seduction was laid against Fleming anyway. The testimony on her part would seem to support the conclusion that it was not she who had pushed for the seduction charge, then. Whether it was due mainly to a lack of evidence, Annie Young's testimony, or a combination of these things plus the seemingly moral and correct character of both parties involved, the case was dismissed.

The evidence would appear to show that both parties had acted within the accepted moral boundaries of society and courtship (if courtship was indeed Fleming's intention with his interactions). Fleming was deemed to have acted the role of the gentleman and Annie the role of the innocent, young and "oblivious" woman who may have simply made some naïve decisions regarding her interactions with him. ${ }^{66}$ Whoever in Annie's life made the initial charge, was likely concerned about the level of interaction between the older man and the younger Annie. Though it was not apparent in the sources available to me, Fleming's class or job might also have had to do with the fears about his interaction with Annie. I was not able to find Fleming in the census records, possibly suggesting that he was one of the many men who travelled from place to place for work. This might have made him a less than desirable candidate. At least one prosecutor shared a suspicion of the interaction between Fleming and Annie enough to bring criminal charges. But why? Perhaps they simply did not trust Annie's description of the

\footnotetext{
${ }^{64}$ Testimony of Annie Laura Young, Regina v. Fleming.

${ }^{65}$ Backhouse, "The Tort of Seduction," 60.

${ }^{66}$ Dubinsky, Improper Advances, 28.
} 
relationship and of Fleming and feared the possibility of having to accept her as an adult or even as a sexual being. Perhaps, too, the parents and prosecutor were swayed by the shifting social spaces in which this courtship occurred.

Annie's testimony places her first meeting with Fleming at the Presbyterian Church in Revelstoke while in the company of her younger brother. This initial meeting was certainly acceptable, as it occurred in a respectable public, social space. Social spaces were important in situations like these. Where a couple met, where they courted and perhaps had sexual encounters, and where they were eventually "discovered" was key to how they were judged by the jury and the public. ${ }^{67}$ Churches were always "healthy" courting spaces. Potentially unhealthy and dangerous social spaces included but were not limited to skating rinks, dance halls, pubs and theatres. ${ }^{68}$

When Annie testified that she "went out for a drive" and "drove more than once" she also made clear that, while the courtship began in the sacred public space of the church, it matured in the profane (and private) spaces accessible by horse-and-buggy. ${ }^{69}$ Activities like skating, dances, picnics, and even berry picking could produce locations for sexual interaction between men and women. Driving or walking to and from these gatherings could also serve as a way to gain time alone and, as Karen Dubinsky points out, "[f]or couples who desired (or, sometimes, when the man desired) to make sex part of their courtship, space and opportunity could be found." ${ }^{70}$ This was the ultimate fear many moral reformists who felt that it was this sexual "disorder" that was pulling down

\footnotetext{
${ }^{67}$ Dubinsky, Improper Advances, 25.

${ }^{68}$ Burke, "Creatures Devoid of Sense and Will," 40.

${ }^{69}$ Testimony of Annie Laura Young, Regina v. Fleming.

70 Dubinsky, “"Maidenly Girls' or 'Designing Women?” 55.
} 
society. ${ }^{71}$ Going on a "drive" together and without supervision would have been one of the key concerns regarding the interactions between Annie and Fleming as it opened up chances for what may have been a "normal" courtship to go awry in a criminal fashion.

The 1895 case of Regina v. Blythe also placed questions of masculinity and jurisdiction at the fore of the conversation. This case differed in one major way from the other cases in that the charge brought against Blythe initially was not seduction at all but a charge of abduction. The charge of seduction only occurred after the charge of abduction in this particular instance was shown to be invalid due to a technicality in the Canadian Criminal Code. Though the discussion of age and chastity were present in a minimal fashion, the main concern in this case seemed to be the actions of the seducer (originally holding the label of abductor), the "possession" of Belle Rockwood, and the jurisdiction of the case itself. After the initial conviction of Robert Blythe, the presiding judge, Chief Justice Davie, felt concern over whether the courts in British Columbia actually had jurisdiction over the case. The ensuing discussion over this was what led, in turn, to the discussion about the "possession" of Belle. ${ }^{72}$ This discussion was not surprising as the laws of the time tended to support and perpetuate a social structure "in which women's virtue was valued predominantly in proprietary terms, to be protected only where their men's assets or lineage was in jeopardy."73

Both Blythe and Belle had initially lived in the United States in the small town of Port Hadlock, Washington (Blythe living with his wife and children) and it was there

\footnotetext{
${ }^{71}$ Burke, "Creatures Devoid of Sense and Will," 40.

${ }^{72}$ Victoria Daily Colonist, 27 August 1895 is the only source I have found in relation to this case so when looking at the information provided one must be especially analytical as there is no other source to turn to regarding the "facts" of the case.

${ }^{73}$ Direct quote from McLaren, "Chasing the Social Evil," 126; see also Burke, "Creatures Devoid of Sense and Will," 55 for a discussion of women as property in relation to the seduction tort.
} 
they began their acquaintance. In March of 1895, Blythe wrote to Belle explaining that he had been accused of a "most horrible crime" and, though he protested his innocence, he also explained that he needed to leave the United States. He travelled to Victoria with his family and from there continued to correspond with Belle, asking her to come and join him. Blythe's letters were, according to the court, "of a seductive character" as he entreated Belle to leave Port Hadlock. He told her that his wife had "got what she wanted" and had left him to be married to a Mr. Larsen. He stressed to Belle that they could be married if she came to Victoria, though not until she had turned eighteen as that was the minimum age of marriage for women in British Columbia (her age at the time of this incident is unstated in the newspaper report).

After multiple letters asking Belle to come, and much discussion of how to embark on the trip in as discrete a way as possible (for fear that her "father and uncle would follow them all around the world" and "fix [him] plenty" if they found out), she finally agreed to come. She stated that she was "glad enough to leave this abominable place." It would seem, then, that though his letters were of a "seductive nature" and though he was, as a married man, very much in the wrong (according to morals of the time) in attempting to persuade this young girl to travel with him out of the country and out of the protection of her family. At the same time, according to her own words, Belle herself was not happy in Port Hadlock living with her parents and was possibly already more inclined to leave than she would have been otherwise. This complicated state of the facts of the case raised judicial concerns over jurisdiction and possession, especially with 
respect to how Section 283 of the Criminal Code should be read in conjunction with the case. $^{74}$

Section 283 read: "Every one is guilty of an indictable offence and liable to five years' imprisonment who unlawfully takes or causes to be taken any unmarried girl, being under the age of sixteen years, out of the possession and against the will of her father or mother, or of any other person having the lawful care or charge of her." Subsections 2 and 3 of this section were also relevant to the discussion as they stated that it was "immaterial whether the girl [was] taken with her own consent or at her own suggestion or not" and that it was also "immaterial whether or not the offender believed the girl to be of or above the age of sixteen." 75 The newspaper article about this case sought to contextualize the specifics of this case citing multiple other trials involving young girls and their abduction (or seduction). The language used in all these cited cases (and perpetuated in the newspaper article printing the story) was the language of possession, ownership, and property rights. For example, one lawyer explicitly likened women to instruments or tools in relation to their parents:

[T] he prisoner had no more right to deprive the father of the girl, of his property as it were, in her, than he would have a right to go into his shop and carry away one of his telescopes or optical instruments. By the same reasoning then, it seems to me, a man, finding a girl under sixteen and discovering her home and parentage, has no more right to deprive the father of the girl, of his property as it were, in her, by keeping her, than would a man finding one of her father's telescopes or optical instruments in the streets, knowing it to be her father's, to keep it and appropriate it to his own use. He would be bound to return the telescope and, so it seems to me, would be to restore the girl. ${ }^{76}$

This discussion epitomized the assumed "normal" relation of fathers and daughters at this time. As Constance Backhouse explains, a “father's right to his daughter's services had always been accepted as a matter of course. In many instances it was not even just

\footnotetext{
${ }^{74}$ Victoria Daily Colonist, 27 August 1895.

${ }^{75}$ Criminal Code, 1892; Amended 1893, Section 283, (2)(3), 219; Emphasis in the original.

${ }^{76}$ Victoria Daily Colonist, 27 August 1895.
} 
services that the father held the rights to but the actual chastity of the girl herself." matter-of-fact tone in the lawyer quoted above makes clear that the concepts under discussion were common knowledge and should really not even have to be explained to those being addressed. Of course, the lawyer seems to be saying, the father had the right of possession over his daughter and of course it was the father who was suffering due to her seduction. He, and not his daughter, was the victim deserving of restitution. In this example, as in countless others from the era, women were legal objects and men legal subjects.

A key question in the Blythe case was whether Belle had already abandoned her father's "possession" by the time she reached Victoria. The answer to this question would determine the charge; abduction or seduction. The argument for abduction was that there "was a continuing possession in the father" and that Belle only left this possession when she disembarked in Victoria after making the decision to go due to Blythe's persuasion in his letters and then the ultimate, his very presence at the dock in Victoria. "By the act of taking," the newspaper reported, "the prisoner severed the connection between the girl and her father, and so took her out of his possession." This loss of possession was determined to have occurred when Blythe met Belle at the boat and from there took her to his home. The alternate argument also pinpointed the meeting on the dock as the key moment, however, the claim was framed differently with the suggestion that if any other person had met her and "taken her in charge" at that moment, it would not have been viewed as an abduction. Though it might be argued that the “prisoner [was] guilty because [Belle's] arrival [in Victoria] was induced by him” it must also then be true that the "inducement must have been offered here. Of that there is no

\footnotetext{
${ }^{77}$ Backhouse, "Tort of Seduction," 50.
} 
evidence." It was also pointed out that Blythe had, in fact, suggested that Belle think seriously about whether she actually wanted to leave her family and had subsequently suggested that if the answer was no, she could immediately get on a boat and return home. It was this argument that, in the end, changed the charge from abduction to one of seduction. What is also interesting to note here is the fact that Blythe asked her explicitly to think about her decision and seemed truly concerned that she understood the decision she was making. Belle confirmed for him that she was happy to go with him still, clearly unhappy with her family life according to her cited letters. There was, it would seem, a consensus between the two, a consensus that was not shared by her family, the law or society generally.

The final verdict from the judge in regard to the changed abduction charge was that he "consider[ed] the conduct of the prisoner scandalous in the extreme, but however bad and unnatural he ha[d] shown himself to be, he ha[d] not brought himself within section 283." ${ }^{78}$ Though the newspaper article discussing this case gives readers but a small window into the proceedings it provides an interesting discussion of some of the discourses around both abduction and seduction and some of the ways they interacted during this time. There was almost no discussion, veiled or otherwise, relating to any sexual act or the sexuality of the couple. Instead what came to the fore, due to the nature of the case and the charges laid, was the gendered power relations between women and their families, most specifically relations between daughters and their fathers in the context of property. Belle was only really discussed as an active participant in the situation insofar as she came to Victoria "[b]y her own inclination." She was viewed quite simply as property, a legal object; who "possessed" her at any given time was how

\footnotetext{
${ }^{78}$ Victoria Daily Colonist, 27 August 1895.
} 
the case was understood and dealt with by the law. Her movement from the supposedly safe space of her family's home and parent's possession into the more dangerous (but clearly desired for her) space of Blythe's home and possession was understood completely differently by the law than it may have been by her. When Belle initially provided her evidence at the trial she denied that any seduction had occurred but later in the process she changed her story, shifting the blame onto Blythe rather than discussing her own choices. Though we cannot know for sure what changed her mind, be it lawyers, her parents, or her own changing wishes and concerns, we can speculate that at the very least her changing views only confirmed the beliefs held by some in the courts and the public that women were easily swayed and seduced and not necessarily to be trusted, especially in situations that involved such immoral and serious matters.

This case thus became more about the discourse of property rights and Blythe's questionable moral fitness as a man and less about Belle's character. If not due to the technicality of the law, Blythe would most definitely have been convicted of the original charge of abduction and been at risk of facing five years in prison rather than two, the maximum for seduction at the time. The character of Blythe was deemed to be wanting by the presiding judge, deeming his behaviour to be "scandalous in the extreme," and though Belle was given partial blame due to her decision to follow Blythe to Victoria, it was the letter of the law and the understanding of Belle's place as the property of another that became important in this case even more so than the perceived morality of those involved. $^{79}$

In the 1899 case of Regina v. Armour there was another even more involved instance wherein the presiding judge, Mr. Justice Walkem, took time after the verdict was

\footnotetext{
${ }^{79}$ Daily Colonist, 27 August 1895; Brode, Courted and Abandoned, 59.
} 
read to share his views about the action and immorality of the man involved in the case.

In this situation the judge's tirade was even more vehement and to the point than the almost offhand comment made regarding Blythe's character by the presiding judge in Regina v. Blythe. Though this case saw an added discourse around the deaf and mute girl who was the subject of Armour's seduction, it was less overt than the discussion of masculinity that emerged over the course of the trial. ${ }^{80}$ After Armour received his guilty verdict, Judge Walkem proceeded to give his very fervent opinions about the facts of the case and the trial itself:

\begin{abstract}
You have had a very fair trial your counsel has taken advantage of every point that could be taken in your favour, and the jury have been exceedingly patient. After careful deliberation they came to a verdict of guilty. My opinion, and as the verdict has been delivered, I may express it, is that had you been indicted for rape the facts would have justified it, although I do not say a jury would have convicted you. You should remember that if you lay hands on a girl, throw her down and she slaps your face in resistance, the crime is that of rape. I shall sentence you to the limit of the sentence allowed under the code, two years. I must say that a more cowardly or dastardly act could not have been committed. The girl had no protection... She was infirm not only mentally but physically... She was afraid of you and never consented to your assault. It was a most cowardly thing to do, and you are best out of the way for a time. If the law allowed me to give you a sentence of five years I should have given you that. ${ }^{81}$
\end{abstract}

This judicial diatribe very much fits with Dubinsky's discussion of the "dramatic and paternal vision of the lives of 'seduced' women," held by many of the men in the judicial system and the reform movement at the time. ${ }^{82}$ There was a growing climate of sexual fear as "social perceptions of female vulnerability soared" and only added to paternalistic worries and discourses. ${ }^{83}$ This vision was especially pronounced due to the extenuating circumstances of this case as the seduced girl was a "deaf and dumb mute," something

\footnotetext{
${ }^{80}$ Victoria Daily Colonist, 04 October 1899.

${ }^{81}$ Victoria Daily Colonist, 19 October 1899.

82 Dubinsky, “"Maidenly Girls' or 'Designing Women'?” 32.

${ }^{83}$ Dubinsky, Improper Advances, 24.
} 
the judge referred to when he pointed to her "infirmity" both mentally and physically. ${ }^{84}$ Charlton's Seduction Act made it clear that "[a]ny person who - Unlawfully and carnally knows, or attempts to have unlawful carnal knowledge of any female idiot or imbecile woman or girl, under circumstances which do not amount to rape... shall be guilty of a misdemeanour" and punished accordingly. ${ }^{85}$ Once again we can see what Foucault means when he speaks of "rendering [language] morally acceptable and technically useful." " Instead of speaking of the act of sex, the act deploys "carnal" as a stand in that was understood to mean sex without having to explicitly speak of it.

This differentiation between seduction and rape was clearly something that Walkem struggled with and the discussion of consent affected his thinking about the differences and similarities between these two charges. The language of the Act itself might suggest that consent was a non-issue, however when it came to the interactions in court it could, and often did, come to the fore. Such was the case with the Armour trial. Walkem seemed to be struggling with this when he made it clear that he believed rape should have been the charge, though he understood there could have been no conviction due to the technicality of the law. ${ }^{87}$

This case not only addressed how some members of the court viewed and understood consent as it related to the specific charge being laid, but it also created an

\footnotetext{
${ }^{84}$ Victoria Daily Colonist, 04 October 1899; Victoria Daily Colonist, 19 October 1899.

85 "The Seduction Act," The Legal News, 194; The language of the Seduction Act here is interesting as the section of the 1892 Criminal Code of Canada relating to seduction has a part specifically related to "Carnally knowing idiots, \&c." The law states that "[e]very one is guilty of an indictable offence and liable to four years imprisonment who unlawfully and carnally knows, or attempts to have unlawful carnal knowledge of any female idiot or imbecile, insane or deaf and dumb woman or girl, under circumstances which do not amount to rape but which prove" that the offender knew of the state of the woman or girl (p. 114). It is unclear in the evidence I have at hand here, then, why Judge Walkem only charged the man under the section of the act specific to a "standard" act of seduction.

${ }^{86}$ Foucault, The History of Sexuality, 21.

${ }^{87}$ Victoria Daily Colonist, 19 October 1899; Backhouse, “Tort of Seduction,” 77.
} 
interesting dynamic in regards to the stated mental and physical disability of the girl involved. The lack of consent clearly bothered Walkem, but it was the girl's condition that seemed to make his zeal all the more focussed as he castigated Armour. Walkem's tirade clearly perpetuated the aforementioned stereotype of the innocent and naïve "maidens" that had to be protected from the "wilful men who came bearing gifts, not guns. ${ }^{" 88}$ She was understood to have lacked both protection and agency.

Part of this protective nature was also seen when he declared that "[h]e certainly would not consider the question raised that the girl's chastity ceased to exist after the first assault." ${ }^{89}$ Once again the discussion turned to the concept of chastity; whether a girl had it previous to her seduction and, once seduced, whether it was considered intact after. The question of this troubled Walkem and was closely related to his thoughts and beliefs regarding consent. As the girl was deaf and mute, she would have been understood at the time to be incapable of consent and so, in Walkem's eyes, also incapable of losing her chastity. Walkem's views were, in some ways, an anomaly. Many of the judges across Canada in the nineteenth-century saw seduction cases as a "repellent species of litigation, and deliberately gave the action a narrow and restrictive interpretation." ${ }^{.90}$ The stereotype of the innocent and naïve female came to the fore so strongly in the Armour case most likely due in large part to the physical and mental condition of the victim. There was, as previously mentioned, the alternate view of the seduction acts as "vehicle[s] for female extortion" and fears about the manipulative natures of women generally. ${ }^{91}$ The seduced female in the Armour case, however, most definitely did not fit the latter description and

\footnotetext{
${ }^{88}$ Dubinsky, Improper Advances, 8.

${ }^{89}$ Victoria Daily Colonist, 19 October 1899

${ }^{90}$ Backhouse, "Tort of Seduction," 63.

${ }^{91}$ Backhouse, "Tort of Seduction," 64.
} 
so the protective and paternal concern of the judge was able to emerge illustrating increasingly prevalent situations whereby the "locus of patriarchy had simply shifted, from individual household heads to legislators and judges." 92

Yet another case that brought out these discussions of masculinity and, through them, the stereotypical understanding of women as innocent, naïve and in need of protection, was Regina v. Johnson in Nelson, British Columbia. ${ }^{93}$ Charged with the seduction of a young Finnish girl who appeared in court with her child, Johnson was seen to sob and weep at his "errors" in front of what one reporter described as, "the morbid delight of a large audience." In the eyes of the reporter writing on the case it would appear that the young woman was in the right here. This illustrates well one of the key concerns with the sources at hand, however. As Paul Rutherford explains, Victorian-era newspapers "sold a package of advertising, entertainment and education, news and views." 94 Their purpose was to informs but also entertain so they could sell, a purpose that could, and did, dictate their content and how it was written. In many cases, there was a focussed commitment to "accuracy, getting all the facts right, but not to the ideal of objectivity." 95 Not only that but we see the description of intense emotion here, more than readers are given in many other cases, however, we are still not privy to the impetus for that emotion. Was Johnson sobbing in earnest for what he had done, sobbing due to the fact that he had been caught or, even simply because he felt it might gain him sympathy and a more lenient sentence? This is but one of the pieces of information that

\footnotetext{
92 Clarkson, Domestic Reforms, 83.

${ }^{93}$ Tribune, 16 April 1898; Again, though Johnson's name appears both as "Johnson" and "Johnston" in the press, Johnson is used most regularly.

${ }^{94}$ Paul Rutherford, A Victorian Authority: The Daily Press in Late Nineteenth-Century Canada (Toronto: University of Toronto, 1982), 115.

${ }^{95}$ Rutherford, A Victorian Authority, 139.
} 
can never be gained from these sources, information that could potentially further our understandings of Victorian masculinities. Can Johnson's experience, or even the experience of his victim, then, ever really be known?

While Johnson was described as an emotional wreck, the victim (who was never named in the newspaper articles used for this analysis) was described as a "young girl of 20 years and pleasing appearance" who was forced to give the "revolting" details of her seduction. At every turn Johnson was portrayed as an active and engaged participant in the proceedings while the girl seemed to be viewed as a passive victim who lacked agency. Whether this was true in actuality or not is irrelevant here, what must be understood is how those in the courtroom and those reading the article after the fact, would have read and understood the femininity of the victim. Though the end result in this case was the discharging of the prisoner, it was (as with Regina v. Blythe in Victoria) due to a technicality of the law rather than what those in attendance felt was deserved. The judge noted his objections and "stated that he would much like to give Johnson the rights he deserved, as it was clearly a villainous case, the prisoner not being willing to support his offspring or marry the girl he had so cruelly wronged." 96 The sympathy quite clearly lay with the wronged woman, but the letter of the law was followed.

John Charlton was definitely onside with these particular views of the women being wronged by seduction. In his second attempt to have his seduction bill passed he declared to the House of Commons, "[i]t is surely a crime to blight a home, to ruin a life; to make an innocent person an outcast of society, and to drive her to prostitution, when

\footnotetext{
${ }^{96}$ Tribune, 16 April 1898.
} 
this is done by the exercise of wiles and false promises.."97 This is something that also emerges in the court records with cases involving judgements of women. There was an increasing fear of a "threat, or perceived threat, to the virtue of decent young women" that took hold even given the simultaneous fears about manipulative women taking advantage of the law and innocent men for monetary gain. The increasing legislation and many of the speeches by judges in court were all put forward in an attempt to "prohibit deviations from sexual standards." The movement of seduction from civil law to criminal law shows this evolution of concern as seduction ceased to "be a matter of property or child support and [became] instead an issue of public morality" ${ }^{98}$ that centred in part around the fear that one of the basic building blocks of society - the family - was being altered in a negative way.

Public morality was a concern that was very much tied up in the legal systems of Canada and, more specifically, British Columbia. The language and discourses that emerged from these trials illustrate concepts of gendered power, sexuality and even property rights. The act of sex itself was rarely explicitly discussed and the closest most laws or courts came to speaking of it was to use the terms "illicit connection."99 Seduction trials seemed to stem from instances wherein courtship had detoured from the socially acceptable path it was expected to follow. A charge of seduction intonated that courtship had gone criminally awry and, in doing so, negatively impacted the family and, in doing so, the morality and strength of a strong society and state. In British Columbia this was especially concerning due to its geographical location on the edge of empire and,

\footnotetext{
${ }^{97}$ Canada House of Commons, Debates, 15 March 1883; Quoted in Dubinsky, ““Maidenly Girls or 'Designing Women'?” 32.

${ }_{98}$ Brode, Courted and Abandoned, 78.

99 Such as in "The Seduction Act," The Legal News, 194.
} 
especially in the case of the Kootenays, its existence as a resource based region with a largely transient male population. How was one to build a morally sound society or state in such conditions?

The solution was to punish the offenders and, in doing so, also educate the public about the dangers of seduction and the growing autonomy of women. Newspapers and legal journals were key in this and it was here that the discourse of the legal community were supported and disseminated to the rest of society. Though generally local newspapers of the time were aimed at and directly concerned with local goings on, there were links to the broader contexts of British Columbia and Canada and these broader ideas of morality and sexuality would have come through in local press reports on seduction. ${ }^{100}$ Though there were fears that this discussion of sexuality and immorality would negatively impact society, it would seem that in most cases a view towards the education of society was taken and the discussion was "rendered morally acceptable and technically useful." ${ }^{101}$ This was not only the case in seduction trials, however, and other legal issues also created windows into these discussions.

\footnotetext{
${ }^{100}$ Rutherford, A Victorian Authority, 135.

${ }^{101}$ Foucault, The History of Sexuality, 24.
} 


\section{Chapter Four}

The Death of Mary Ellen Janes:

Abortion, the Law, and the Construction of Respectable Masculinity

in Victoria, British Columbia

On Saturday, 14 December 1895 the Victoria Daily Colonist published a story detailing the Coroner's Inquest investigating the recent death of Miss Mary Ellen Janes of 13 Green Street in Victoria, British Columbia. ${ }^{1}$ She died at 8:00 PM on Wednesday, 11 December 1895 as a result of septicaemia. The reason for the inquest, however, was due to concern over how Mary Ellen had developed blood poisoning in the first place. Most of the doctors involved in Mary Ellen's case conceded in their initial testimony for the coroner that the evidence at hand suggested a pregnancy, approximately two to three months along, and a subsequent abortion. None, however, seemed willing to "swear positively to the cause of death."2 Despite this, just a few days after the initial Coroner's Inquest Dr. John Kaye Garrow, the doctor who had performed the abortion, and Mr. Harry Creech, Mary Ellen's fiancé of approximately four years, were arrested. Garrow was charged with murder and Creech was charged with accessory before the fact in relation to Mary Ellen's death. According to the news story that ran the day following their arrest, this was not a surprising outcome given the direction the evidence had taken during the inquest. ${ }^{3}$ The findings of the inquest soon became a matter for the courts and witnesses were called once again to give testimony. At the center of all of this discussion existed a discourse of medical "fact" and legal technicality as well as clearly gendered understandings of the character of the two men charged and also that of the deceased,

\footnotetext{
${ }^{1}$ Victoria Daily Colonist, 14 December 1895; Victoria Daily Colonist, 17 November 1895.

2 "Regina v. Garrow and Creech," British Columbia Law Reports, Volume V (Victoria, BC: The Province Publishing Company, 1898), 63.

${ }^{3}$ Victoria Daily Colonist, 17 December 1895.
} 
Mary Ellen Janes. Indeed, as much as the case file, law reports and newspaper articles written around the trial were all trying to solve the riddle of how Mary Ellen died, they also helped perpetuate and construct the gender identities of all involved.

At the time of her death, Mary Ellen Janes was twenty-three years old and living with her mother and three brothers. ${ }^{4}$ Her father, Alfred Janes, was of English origin while her mother, Jane Janes, was American by birth. Mary Ellen and her three brothers (George Alfred, Charles Edwin and Frederick) were all born in the United States and, after living in Salem, Oregon for a portion of their early life, ${ }^{5}$ immigrated to Canada sometime before 1881 where Alfred Janes identified his occupation as farmer on the 1881 census. ${ }^{6}$ In 1884, Mary Ellen's father died due to heart disease and asthma leaving his family in less than desirable financial straits. Presumably to help make ends meet, Mary Ellen began work as a seamstress (giving most of her earnings to her mother to help with the supporting the family $)^{7}$ and her mother took on the running of a boarding house. Her brothers also contributed to the family's economy. George Janes was, at the age of sixteen, working as a cabinet maker $^{8}$ (though by the time of Mary Ellen's death he worked as a shingler) ${ }^{9}$ and Charles Janes worked as a book-binder. ${ }^{10}$ According to witnesses at the trial, Mary Ellen was well liked around their working class

\footnotetext{
4“"Regina v. Garrow and Creech," British Columbia Law Reports, 61; Victoria Daily Colonist, 17 December 1895.

${ }^{5}$ Victoria Daily Colonist, 14 December 1895.

${ }^{6}$ Census 1881 - Recensement, Province of British Columbia, District Number 190, S. District: Johnson Street Ward, Edgar Fawcett, p. 81.

${ }^{7}$ Testimony of Jane Janes, p. 21, Regina v. Garrow and Creech, file 1896/28, box 64, GR-0419, British Columbia Archives.

${ }^{8}$ Census of Canada 1891, Province of British Columbia, District Number 4 - Victoria City, S. District: Johnson Street Ward, Robert Dudgeon, Enumerator, p. 35.

${ }^{9}$ Testimony of George Alfred Janes, p. 42, Regina v. Garrow and Creech, file 1896/28, box 64, GR-0419, British Columbia Archives.

${ }^{10}$ Testimony of Charles Edwin Janes, p. 43, Regina v. Garrow and Creech, file 1896/28, box 64, GR-0419, British Columbia Archives.
} 
neighbourhood in the Johnson Street area of Victoria. ${ }^{11}$ She was rarely seen out with anyone but her fiancé, Harry Creech, who had become a regular visitor to the Janes household approximately five years previous to her death. It was agreed by almost all who testified that Mary Ellen Janes possessed a "good character." 12 How, then, did she end up involved in a situation that led so quickly to her death?

This was the question that led to both a coroner's inquest and then a trial, both of which were covered in the press, and it is a question which is also at the heart of this chapter. Much as we saw in the previous chapter on seduction cases, this abortion case was steeped in discourses about gender, class, and sexuality, and in the politics of social purity and state formation in late nineteenth-century British Columbia. To make sense of what happened at the trial, and what became archived in the case file, we must first turn to the connections between the Victorian politics of abortion and the professionalization of medicine. This relationship played a determinative role in not only what happened to Mary Ellen but also in how her death galvanized a very public discussion about morality, health, and the public good. The second half of the chapter then turns to a closer reading of the inquest and trial to show about these politics played themselves out in the contingencies of time, place, and circumstance connected to Mary Ellen's fateful last days.

\footnotetext{
${ }^{11}$ Patrick Dunae discusses some of the different neighborhoods that existed in late-nineteenth century Victoria in "Sex, Charades and Census Records: Locating Female Sex Trade Workers in a Victorian City," Histoire Sociale/Social History, 42, 84 (November 2009), 267-297. He identifies the Johnson Street Ward as one of the areas in the city that was known for the presence of sexual commerce.

12 Testimony of Mrs. Maria Wallenstine, p. 27, Regina v. Garrow and Creech, file 1896/28, box 64, GR0419, British Columbia Archives; Testimony of Mrs. Lenora Castleton, p. 29, Regina v. Garrow and Creech, file 1896/28, box 64, GR-0419, British Columbia Archives.
} 


\section{The Politics of Abortion, Medicine, and the Law}

Those involved in both the inquest and the subsequent court case felt that the answer to many of the questions concerning Mary Ellen's death could be derived most directly from the medical evidence at hand. In the mid-nineteenth century, scientific discourse and understandings began to acquire a great deal of social and cultural capital, and physicians became influential "experts" of both bodily and moral health. ${ }^{13}$ Partly due to the decline of clergymen, by the late nineteenth century physicians took on important roles in "both social purity and urban reform generally" so that "when they spoke about immorality, their judgements had all the authority of science merely by virtue of their professional status. ${ }^{" 14}$ As Constance Backhouse has demonstrated, their authority as scientific experts also translated into the courtroom. ${ }^{15}$ The "moral appropriation of scientific discourse" was not uncommon during this period of growing social reform. That did not mean, however, that there were not still concerns about how medical evidence could be used and what it could tell contemporaries about a case.

Deriving answers about the death of Mary Ellen was more complicated than "simple" medical evidence and science could offer. Indeed the very case file created and archived around the trial seemed to acknowledge as much in the form of a few lines that precede the printed testimonies of witnesses: "in proving death by poison, the evidence of medical men is frequently required and in applying that evidence to the facts of the case it

\footnotetext{
${ }^{13}$ Franca Iacovetta and Wendy Mitchinson, "Introduction: Social History and Case Files Research," in On the Case: Explorations in Social History, eds. Franca Iacovetta and Wendy Mitchinson, (Toronto: University of Toronto Press, 1998), 10.

${ }^{14}$ Mariana Valverde, Age of Light, Soap and Water: Moral Reform in English Canada, 1885-1925 (Toronto: University of Toronto Press, 1991; reprint 2008), 47.

${ }^{15}$ Constance Backhouse,_Petticoats and Prejudice: Women and Law in Nineteenth-Century Canada (Toronto: Osgoode Society, 1991), 163.
} 
is not unusual for difficulties to occur." ${ }^{16}$ Difficulties were certainly observed in the courtrooms of Victoria in 1895 and 1896 as judges, lawyers, and a range of "expert" and "lay" witnesses sought to figure out how and why Mary Ellen Janes died so suddenly. Indeed, the medical evidence provided by the physicians involved in the Mary Ellen Janes case was, at times, conflicting and confusing regarding both the drugs involved in the abortion as well as the medical findings during the treatment and post mortem.

This was not unusual during court cases involving medical evidence in late nineteenth century as evidenced by a later 1901 case in Victoria. Involving the death of multiple children who, it was believed, had received improper care for diphtheria and croup from their parents who supported methods of faith healing rather than the science of regular physicians. The parents of the children were charged and during the trial, as James Opp argues, their lawyers ably turned the "focus from the defendants' religion to medical ambiguities surrounding diptheria, croup, and medical treatment. Very quickly, the courtroom became immersed in issues of diagnostics and therapeutics rather than scrutinizing the practice of divine healing. At times it was unclear if it was the doctors or the defendants who were on trial.” This case particularly provided evidence of the still divisive understandings of modern medicine as opposed to methods of healing used by faith healers and irregular physicians. It could, and did, dramatically affect the outcome of court cases that relied heavily on medical evidence. ${ }^{17}$ In the case of the Garrow and Creech trial, as we shall see, the judgement reached by the courts became about more

\footnotetext{
${ }^{16}$ Preamble, "Roscoe, $10^{\text {th }}$ Ed. 755," Regina v. Garrow and Creech, file 1896/28, box 64, GR-0419, British Columbia Archives.

${ }^{17}$ James Opp, The Lord for the Body: Religion, Medicine and Protestant Faith Healing in Canada, 18801930 (Montreal and Kingston: McGill-Queens University Press, 2007), 107; Though Dr. Garrow himself does not appear in Opp's book, Dr. Ernest Hall, Dr. Frank Hall, and Dr. Roderick Fraser are all present. In Opp's book, as in this thesis, these doctors are present due to their involvement in criminal cases and their presence in the legal records due to their testimony on their involvement in the medical aspects of the cases.
} 
than what the scientific medical evidence had to say. The personal characters of the accused men, as well as the character of the victim herself, were brought into play both intentionally and unintentionally by all of the people involved and, ultimately hegemonic codes of morality and gender became a key part of the decision making process regarding the fate of Harry Creech and Dr. John Kaye Garrow.

Abortions involved both men and women and, due to the criminalization of the procedure in Canada in 1869 and again in 1892, also involved provincial judicial systems. As Angus McLaren observes, the witness testimony and court findings for many cases involving abortion between 1886 and 1939 tended to exaggerate the "unfortunate fate of women who aborted" while also "minimizing the role of the men involved." Unfortunately for some, however, this only seemed to apply to married men who could prove that their involvement was minimal and well within their "rights" as a husband. There were other situations where the man in question was single and, "failing to abscond, became entangled in the law." ${ }^{\prime 18}$ This second scenario can be applied to Harry Creech as he was both considered single (Creech and Mary Ellen were only engaged, not officially married) and entirely too involved in the situation according to the accepted understanding of propriety at the time. Though Jane Janes (Mary Ellen's mother) testified that she allowed Creech's “constant attendance" of Mary Ellen "because they were engaged," other testimony from close friends and neighbours made it clear that they were surprised at the level of interaction that was allowed to occur between the two. ${ }^{19}$

\footnotetext{
${ }^{18}$ Angus McLaren, "Illegal Operations: Women, Doctors, and Abortion, 1886-1939," Journal of Social History, 26, 4 (Summer 1993), 798.

${ }^{19}$ Testimony of Jane Janes, p. 23, Regina v. Garrow and Creech.
} 
There was a gendered power dynamic occurring with the treatment of the relationship between Creech and Mary Ellen on the part of witness testimony and the court system. Both of these dynamics can be understood within the documents of the case file. By understanding how they work together and interact, one can see the way that gender and power become entangled in questions of blame, legality, the roles of men and women and, most apparently, morality. Throughout all of this discourses of masculinity and femininity were present and only adding to the already apparent constructions of these norms that existed in late-nineteenth century Victorian society. These constructions were also key parts of the regulation and governance of this very same society.

The concern with morality was, and still is to some degree, ingrained in these discussions of gender and power. Not only that but there was a more specific concern with sexuality that went hand in hand with the ideas of morality that occurred. Moral regulation can be seen as viewed through, and codified by, the law. These subtle interactions between the state and the population are evident when one avoids viewing the information in the case file as simple or containing true "facts" and instead tries to better understand the underlying discourses and dynamics at work. Case files that deal with abortion are especially related to the intertwining of government, moral regulation and legal theory. Law is, and was, very much a tool of the state and with the increasing involvement of the state in abortion through the creation of new, anti-abortion legislation, case files relating to abortion have become a good way to unpack these complicated discourses of gender, power, sexuality and morality. 
The relationship between moral regulation, the law, and governance with respect to abortion was both complex and contingent. As Angus MacLaren explains, abortions were "not carried out in isolation; they were social acts the investigations of which reveal the particular nature of the relationships of women... with their male partners, their friends, their doctors, and ultimately the judiciary." ${ }^{20}$ These cases can clearly not be viewed in terms of total state control. Sociologist and moral regulation theorist Alan Hunt would also appear to support this claim as he adamantly asserts that moral regulation must be discussed with reference to both agency and population. The discussion must apply both to the people working within the state as well as the population being governed by the laws of the state. ${ }^{21}$ This view can be found within the newspaper articles, the law reports and the witness testimonies regarding the Janes case. What comes through in all is the concern with the (im)morality of the people involved and of the moral geography of the bedroom in Mary Ellen's family's home in the working-class district of Victoria where she spent her last days.

When Mary Ellen and Harry (as we shall see who, exactly, made this decision was never resolved) sought out medical help from Dr. Garrow, all three became enmeshed in a complex web of laws, attitudes, and cultural politics related to abortion. The mid to late-1800s saw an increase in anti-abortion legislation as the "state and the professions took an unprecedented interest in the fertility control decisions of ordinary men and women." ${ }^{22}$ As was the case of seduction legislation, abortion was included in the 1892 Criminal Code of Canada under the section, "Title V - Offences against the

\footnotetext{
${ }^{20}$ McLaren, "Illegal Operations," 797.

${ }^{21}$ Alan Hunt, Governing Morals: A Social History of Moral Regulation (Cambridge: Cambridge University Press, 1999), 18.

${ }^{22}$ McLaren, "Illegal Operations," 798.
} 
Person and Reputation" and the subsection, "Part XXI - Rape and Procuring Abortion." One could be charged with, among other things, the killing of an unborn child, "using means to procure abortion," and a woman could be charged for "using means to procure her own abortion," or "supplying means to procure abortion." ${ }^{, 23}$ This increased concern with abortion occurred for varied and complicated reasons that included, but were not confined to, fears about the direction that morality, and society with it, were taking. This was also tied up in concerns that have been discussed throughout the entirety of this thesis; concerns about the sexuality of women and anxieties about them having sex for reasons other than procreation. It was also connected with professional anxieties about the encroachment of "irregular" physicians (generally unprofessional or unqualified medical practitioners) on the work of the "regular" physicians (almost all men who had completed some form of training so as to be considered qualified medical practitioners). ${ }^{24}$

While the debates over "irregular" and "regular" doctors was not something that came through as a key part of the Janes case, the professional boundary-work and associated politics of identity were readily apparent in the statements of the physicians involved as they each clearly stated at the beginning of their testimony, "I am a duly qualified medical practitioner." ${ }^{25}$ The professionalization of medicine was also apparent

\footnotetext{
${ }^{23}$ Criminal Code, 1892; Amended 1893, Table of Contents, xx.

${ }^{24}$ Though in subsequent pages the quotations around "regular" and "irregular" are dropped the reader should remain aware of the problems and connotations associated with words such as these; Backhouse, Petticoats and Prejudice, 141-142; Wendy Mitchinson, The Nature of Their Bodies: Women and Their Doctors in Victorian Canada (Toronto: University of Toronto Press, 1991), 139; Opp's The Lord for the Body is also relevant here as he discusses the interactions and tensions that emerged among of religion, medicine and Protestant faith healing in Canada during the late-nineteenth and early-twentieth century. The tension between regular and irregular physicians is clearly present throughout his work.

${ }^{25}$ Testimony of Francis Walter Hall, p. 4, Regina v. Garrow and Creech, file 1896/28, box 64, GR-0419, British Columbia Archives; Testimony of John Lang, p. 8, Regina v. Garrow and Creech, file 1896/28, box 64, GR-0419, British Columbia Archives; Testimony of Ernest Amos Hall, p. 13-14, Regina v. Garrow and Creech, file 1896/28, box 64, GR-0419, British Columbia Archives; Testimony of John Kaye Garrow, p. 34, Regina v. Garrow and Creech, file 1896/28, box 64, GR-0419, British Columbia Archives; Testimony of
} 
in the way Garrow advertised his practice in the Victoria Daily Colonist by referencing his previous work experience at Guy's Hospital in London and the Royal Infirmary in Edinburgh. He also, prophetically, included in his advertising: "Specialties:- Diseases of Women \& Children and Chronic Diseases"26 This presentation of his self as a doctor lent an air of professionalism to his work, ensuring that he was included in the ranks of regular physicians. His office address placed his practice at Douglas and Pandora street, an area that was within the borders of one of the "respectable" districts in Victoria, something which also added to the professional reputation he was clearly attempting to build in the capital. It was these professional members of society that were expected to hold Victoria up to the rest of the province as a place of progress and modernity and serve as a model for the rest of society. ${ }^{27}$ As discussed in Chapter Two of this thesis, the city's modern amenities of gas, water and "electric light" were held up as examples of how Victoria had progressed; doctors like Garrow and their medical knowledge and increasing associations with social purity and morality, would only continue to perpetuate this constructed image of British Columbia's capital city. ${ }^{28}$

With a speciality in "diseases of women and children" Garrow was likely aware of the resentment that many physicians held towards the encroachment of the law into their profession, feeling that it was an unnecessary involvement in their work on the part

Roderick Fraser, p. 29, Regina v. Garrow and Creech, file 1896/28, box 64, GR-0419, British Columbia Archives.

${ }^{26}$ Victoria Daily Colonist, 20 December 1889; Garrow ran his advertisement (which also included the address of his office and residence on Douglas and Pandora Street and his office hours) on a regular basis in the Victoria Daily Colonist, right up to the 1890s.

${ }^{27}$ R.D. Gidney and W.P.J. Millar's, Professional Gentlemen: The Professions in Nineteenth-Century Ontario (Toronto: University of Toronto Press, 1994) provides an in depth discussion of these ideas. As previously mentioned the term "professional" was often understood in a restrictive sense by Upper Canadians who "applied it almost exclusively to divinity, medicine, and the law - the three 'learned' or 'liberal' professions, whose origins dated back to the medieval universities and beyond," (p. 3). These were the people required to create a more "civilized" society in British Columbia and Victoria particularly.

${ }_{28}$ Alexander Begg, ed. Begg and Lynch's Hand-Book and General Guide to British Columbia, vol. 1, no. 2 (Victoria, BC: The B.C. Guide Publishing Company, 1893), 88. 
of the state. At the same time, it was these very same professionals and regular physicians mentioned previously that had originally lobbied for the stricter legislation. ${ }^{29}$ One significant reason for this concerned their attempts to combat the increasing influence of the irregular medical practitioners. Since these irregulars tended to include women, ethnic and racial minorities, and midwives, they were seen as less capable and not as up to date with the medical technology and science that was becoming more recognized as a standard for practicing medicine. They were also not bound by the Hippocratic Oath as regular physicians were and so were viewed as having more leeway when it came to making decisions about performing abortion. This did not mean that they necessarily supported or even approved of abortion, but it did create a situation whereby one group was restricted specifically by a required oath and the other was considered freer to perform this contentious medical, and now illegal, medical procedure.

This same situation also created the fear that the irregular doctors could benefit from the possibility of gaining new patients (and through this more income) by performing procedures that regular doctors would not. Regulars were also concerned that patients who did receive this care would then turn to irregulars for all of their medical needs on a more consistent, if not permanent, basis. ${ }^{30}$ There was a competition between the two groups as most regular doctors competed for fees in an "unrestricted market not only against each other but against the homeopaths, the eclectics, the druggists, the midwives, and various other practitioners." ${ }^{31}$ James Opp argues that, as these divides

\footnotetext{
${ }^{29}$ Reva Siegel, "Reasoning From the Body: A Historical Perspective on Abortion Regulation and Questions of Equal Protection," Stanford Law Review, 44, 2 (January 1992), 282.

${ }^{30}$ Backhouse, Petticoats and Prejudice, 149.

${ }^{31}$ Gidney and Millar, Professional Gentlemen, 86; Gidney and Millar also point out that terms like "quack" and "irregular," though generally associated with doctors and the medical field, were also applied to the other main professionals of the late-nineteenth century, the clergy and lawyers, and were " used not so
} 
deepened, "the professional identity of physicians was increasingly associated with the science of medicine rather than the actual practice of medicine."32

Regular doctors were therefore able to point to irregulars who performed abortions as a way to further highlight the benefits and propriety of regulars over irregulars. They could maintain their place as the dominant group of medical practitioners by emphasizing their professionalism. Again, this was apparent in the Janes case as every doctor who testified at the trial gestured towards their professionalization when they claimed their qualifications at the outset of their testimony. Part of this move towards a more regulated and professional role for doctors was to bring more attention to the issue of abortion and, in doing so, be able to point out the irregulars as "traffickers in human life," who were "unlicensed and unqualified to practice medicine." Anti-abortion legislation would, physicians hoped, help to counteract these issues. ${ }^{33}$ Regular physicians also feared the declining birth rate of the "respectable classes" (generally those in the middle and upper classes). At this time it was considered unfashionable by many in these class groups to have a large family and abortion was, in many cases, used as a form of family planning and control. With many in the lower classes having quite large families it was hoped that this too could be counteracted with stronger legislation against abortion. ${ }^{34}$

With these changing dynamics came the further rise of the regular physician as a dominant and powerful member of society. Tied to the growing faith in the new

\footnotetext{
much to indicate a differential level of skill as to distinguish between those who were 'authorized,' who were regular and respectable, and those who were deemed not to be," (p. 12).

${ }^{32}$ Opp, The Lord for the Body, 27.

${ }^{33}$ Backhouse, Petticoats and Prejudice, 149.

${ }^{34}$ Backhouse, Petticoats and Prejudice, 147; McLaren, "Illegal Operations," 805; Siegel, "Reasoning From the Body," 285.
} 
"scientific discourse" which gave people new and tangible ways of "distinguishing truth from falsity, natural from unnatural," this situation particularly affected women and their interactions with the men who were their doctors and their partners. ${ }^{35}$ Physicians were now both regulated and licensed by the state, they performed what were seen at the time as cutting edge operations, and provided the population with all the newest medicine and technology. They were trusted by members of society to know how best to treat sickness and because of this many documents that physicians have contributed to in the past have allowed readers to better understand what the sickness of the time was "thought to be." Wendy Mitchinson's The Nature of Their Bodies discusses the normative nature of health. Good health was defined by the norm, while those who were ill or sick were seen as outside the norm and therefore deviant. ${ }^{36}$ Women especially were part of this system of normativity and with the stronger legislation against abortion, those involved were part of the enforcement of women's roles, "an objective...justified with arguments concerning women's bodies. ${ }^{37}$

This was the context that Mary Ellen Janes found herself in when she initially went to Dr. Garrow seeking an abortion, and that Dr. Garrow and Creech found themselves in when they were charged with murder and an accessory to murder respectively. The moral and legal connotations that were attached to the act of abortion, for both the doctor performing the abortion and the woman seeking it, created a set of very specific circumstances that can, in many ways, be carefully viewed through the case file documents left behind. The people are categorized by gender, class, relationship status and character and as one moves through the documents contained in the case file

\footnotetext{
${ }^{35}$ Iacovetta and Mitchinson, "Introduction," 10.

${ }^{36}$ Mitchinson, The Nature of Their Bodies, 4.

${ }^{37}$ Siegel, "Reasoning From the Body," 265.
} 
there can be, as was suggested previously, a tendency to believe one has found all of the answers. While the idea that the "truth" of the case, and the people involved, can be fully understood through it is invalid, there is still much that can be gained and understood through these documents as long as an awareness of these problems is present. By understanding that one is viewing the people discussed in the case file through a specific gaze (that of the legal system and contemporary social hierarchy), the intertwining of legal discourse, moral regulation, and gender politics can be viewed. The Janes case file is a good way to view the attempted regulation of specific members of society through the specific regulation of abortion though one must always remain aware that in most cases, the abortions only came to light specifically because they were fatal.

\section{The Case of Regina v. Garrow and Creech}

On 06 December 1895, Mary Ellen Janes complained to her mother that she was not feeling well. Her fiancé of four years, Harry Creech, rented a buggy and, after informing Mary Ellen's mother that he would take her to the family physician, Dr. Frank Hall, proceeded to take her to Dr. John Kaye Garrow instead. Mary Ellen had previously visited Dr. Garrow by herself on November 30 and had received a prescription for ergotine, a drug that was sometimes used to bring on an abortion though the actual effects of the drug were much debated. ${ }^{38}$ It was prescribed to her at the time in response to her complaint of nausea and an upset stomach. Importantly, it was Harry and not Mary who had the prescription filled and picked it up from the apothecary. On her return visit to Dr.

\footnotetext{
${ }^{38}$ The controversial debates around ergotine were discussed by all of the physicians who testified at the Janes trial as they made it clear that some medical men felt it was very useful, others understood it to be incredibly dangerous and still others saw it as a useless drug not to be used in any situation. Most did agree, however, that it was a recurring drug in situations where abortion was attempted. There is no extensive history of the drug as it related to abortion in the nineteenth century.
} 
Garrow on 06 December, this time accompanied by Creech, Mary complained of "intractable vomiting." Garrow treated this ailment by inserting a device called a "sound" into her uterus. ${ }^{39}$

After the appointment Creech took Mary Ellen home where she continued to experience and complain of abdominal pain. On the following day, 07 December, Creech visited Dr. Hall and asked him to come to the Janes' house to check up on her. ${ }^{40}$ Once Creech explained the nature of the situation, however, Dr. Hall refused to get involved. He made it quite clear (at the time of the requested visit and again in his testimony during the inquest and court case) that he did not want to get involved in a case of "that kind" and instead suggested that Creech rely on Dr. Garrow as he had been the original physician. ${ }^{41}$ As discussed previously, performing an abortion at this time was a contentious issue and a case involving a botched abortion, as Mary's appeared to Dr. Hall, was unsettling for moral and/or legal reasons. His reticence to get involved was thus not surprising. ${ }^{42}$

Though Dr. Hall initially declined to get involved, Creech was persistent. After four more visits to Hall's office on the next day, 08 December (a Sunday no less), Creech was able to convince him to come to the Janes' home that night at 8:00 PM. Dr. Hall made an initial examination, noting Mary Ellen's temperature, respiration and pulse, before completing a vaginal examination and removing something that he described at

\footnotetext{
39 "Regina v. Garrow and Creech," British Columbia Law Reports, 61-62; A "sound," in this instance specifically a uterine sound, is a medical instrument (still used today in medicine) that is used to dilate and measure a woman's uterus. In the late nineteenth-century it was used to treat uterine troubles though most of the doctors called to testify in the Mary Ellen Janes case commented that they would not use a sound on a woman unless they were absolutely sure she was not pregnant as it could be the cause of an abortion.

${ }^{40}$ Handwritten Note, Timeline of Events, Regina v. Garrow and Creech, file 1896/28, box 64, GR-0419, British Columbia Archives.

${ }^{41}$ Victoria Daily Colonist, 14 December 1895; Testimony of Francis Walter Hall, p. 2, Regina v. Garrow and Creech.

${ }^{42}$ McLaren, "Illegal Operations," 807.
} 
the inquest as "not as big as a hen's egg."43 He did not positively identify the mass but said it could have been an ovum, a placenta, a "mucous membrane of the uterus, or an organized blood clot." This ambiguity regarding the identification of the mass was partly due to the fact that he did not perform a proper examination of it and it would appear to be especially relevant for the defense in the court case later as notes included with the case file show that the attempts to understand exactly what had happened were ongoing. ${ }^{44}$ Dr. Hall's diagnosis at the time of his first examination of Mary Ellen was septicaemia and he prescribed "hot water douches and quinine administered internally.",45

Dr. Hall returned once again to the Janes household at 4:00 AM on Tuesday, December 10 and strongly suggested that Creech take Mary Ellen to the hospital where she could undergo an operation to greatly improve her chances of survival. Creech did not comply and instead requested that Dr. Hall come once again at 8:00 AM. It was at this time that Dr. Hall decided that Mary Ellen was now too weak to be taken to the hospital and instead called in another physician, Dr. Roderick Fraser, to serve as a consultant on the operation. ${ }^{46}$ This course of action on the part of physicians getting involved in possibly controversial cases was quite common at the time. Asking another physician to consult on these cases served as a way of protecting ones' reputation in the case of a trial or inquest. ${ }^{47}$ The operation seemed to improve Mary Ellen's condition and on the following morning Dr. Hall and Dr. Fraser once again visited, this time with yet

\footnotetext{
43 “Regina v. Garrow and Creech," British Columbia Law Reports, 61; Victoria Daily Colonist, December 14,1895 .

${ }^{44}$ Handwritten Note, Possible Causes for Mary Ellen's Septicaemia, Regina v. Garrow and Creech, file 1896/28, box 64, GR-0419, British Columbia Archives; Testimony of Francis Walter Hall, p. 4, Regina v. Garrow and Creech; Emphasis in original.

45 Testimony of Francis Walter Hall, p. 4, Regina v. Garrow and Creech.

46 "Regina v. Garrow and Creech," British Columbia Law Reports, 62.

${ }^{47}$ McLaren, "Illegal Operations," 807.
} 
another consulting physician, Dr. Ernest Hall (no relation). ${ }^{48}$ Since the previous visit Mary Ellen had once again deteriorated Dr. Francis Hall requested that Creech let him know if she was still alive by 9:00 PM that night and, when he had not heard from him by that time he assumed that she had died. Creech confirmed these suspicions the following afternoon when he came to Dr. Hall's office to inform him of Mary Ellen's death. ${ }^{49}$

Soon after Mary Ellen's death the inquest began and those involved were called to testify to both the "facts" of the incident (the dates, times and places involved) and the character and intent of the people who were involved. Witnesses called to testify to the jury included, among others, Dr. Garrow, Dr. Frank Hall, Dr. Ernest Hall, Harry Creech, and Mrs. Jane Janes, Mary Ellen's mother. The inquest concluded on 16 December and the findings of the jury were announced the next day in the Victoria Daily Colonist. The jury concluded that Mary Ellen had died "by blood poisoning, a result of improper medical treatment by Dr. Garrow, although without criminal intent.” They censured Creech for his "ungentlemanly actions in and around the house of the deceased Miss Janes, and for trying to blacken her character while giving his evidence before [the] jury." The jury also commented on the actions of Dr. Frank Hall by stating their surprise regarding his hesitance to take up the case in the first place. The jurors clearly felt that the men in Mary Ellen's life had failed her, and Garrow and Creech were seen as especially responsible for her death. Though it was Dr. Garrow who was the one charged with murder initially, the witness testimony seemed to suggest that Creech was the one who was more at fault in a moral capacity, if not in actual physical fact. The personal characters of both Mary Ellen and Creech came under close scrutiny and were a

\footnotetext{
${ }^{48}$ Victoria Daily Colonist, 14 December 1895.

${ }^{49}$ Testimony of Francis Walter Hall, p. 4, Regina v. Garrow and Creech.
} 
significant part of the final decision made by the jurors at the inquest. They would also come into play once again with the testimonies given during the court case. ${ }^{50}$

Mary Ellen's mother described her daughter as a generally healthy young woman. Though Dr. Frank Hall described her as a "very delicate girl of a very weak constitution" ${ }^{51}$ when he saw her on the night of 07 December, the testimony of Jane Janes was corroborated with subsequent evidence that proved that Dr. Frank Hall "knew Miss Janes by sight" but "did not see much of her before her death." 52 What is also apparent from Mrs. Janes' testimony, however, is that she did not seem to have any concrete knowledge of her daughter's situation. Even when Dr. Hall and Dr. Fraser operated on Mary Ellen in the Janes' household she remained unaware of the reason for the operation. ${ }^{53}$ Mrs. Janes testified that her daughter had never told her specifically of the trouble she was in and Creech had only informed her that Mary Ellen had a bad cold. ${ }^{54}$ When Dr. Frank Hall had finished his initial examination of Mary Ellen and was providing instructions for treatment he gave the information to Creech as "the mother appeared passive." 55 It was only after her daughter's death that Jane was made aware of what had occurred. She had, according to her testimony and actions, trusted Creech and "had great confidence" in him. ${ }^{56}$ This lack of knowledge on the part of Mrs. Janes would appear to be corroborated by the testimony of Mrs. Wallenstine, a neighbour and friend of the Janes family. The testimony of Mrs. Wallenstine also supplied a commentary on what she felt was the inappropriate passivity and distance of Mary Ellen's mother from

\footnotetext{
${ }^{50}$ Victoria Daily Colonist, 17 December 1895.

${ }^{51}$ Testimony of Francis Walter Hall, p. 6, Regina v. Garrow and Creech.

${ }^{52}$ Handwritten Note, Regina v. Garrow and Creech, file 1896/28, box 64, GR-0419, British Columbia Archives.

${ }^{53}$ Victoria Daily Colonist, 14 December 1895.

${ }^{54}$ Testimony of Jane Janes, p. 22, Regina v. Garrow and Creech.

55 Testimony of Francis Walter Hall, p. 3-4, Regina v. Garrow and Creech.

${ }^{56}$ Testimony of Jane Janes, p. 24, Regina v. Garrow and Creech.
} 
the ongoing and close interactions between Creech and Mary Ellen. Though Jane Janes clearly felt that the relationship was appropriate due to their engagement, other onlookers did not.

Mrs. Wallenstine was called as a witness with the re-opening of the inquest after charges had been laid against Dr. Garrow and Creech. She was called to the stand due to her presence in the Janes household during the illness and then death of Mary Ellen. Her testimony made it very clear that the findings of the jury regarding the conduct of Creech were supported by her entirely. She felt that by allowing Creech so much leeway, Mrs. Janes was, in a sense, relinquishing control of her own household. Creech was present through the entirety of Mary Ellen's sickness and was never further from her than he had to be. He would hover in her room and even at times lay on the bed with her. There was never any time at which the other women in the room could speak privately with Mary Ellen regarding her condition. ${ }^{57}$ Even Dr. Francis Hall commented on his inability to get information out the patient when he stated "I tried to find out from the patient if it was true what Creech had told me but she would not answer." ${ }^{, 58}$ It would appear that in this situation, Creech held the upper hand even when not necessarily present.

Mrs. Wallenstine disapproved and stated firmly in her testimony that his intentions and character were far from honourable. At one point she even described a brief period when Creech had locked himself in Mary Ellen's room with her alone. Mrs. Wallenstine had gone briefly to the kitchen to warm some milk for her and when she returned the door was locked. She went back down to the kitchen, waited five minutes and once again returned to Mary Ellen's room. The door was still locked and only a few

\footnotetext{
${ }^{57}$ Victoria Daily Colonist, 17 December 1895; Testimony of Mrs. Maria Wallenstine, p. 25-26, Regina V. Garrow and Creech; Testimony of Lenora Castelton, p. 29, Regina v. Garrow and Creech.

${ }^{58}$ Testimony of Francis Walter Hall, p. 5, Regina v. Garrow and Creech.
} 
minutes after she had knocked would Creech open the door. He informed Mrs.

Wallenstine that he had given Mary Ellen the physician prescribed brandy and though she attempted to confirm this with Mary Ellen, the girl was uncommunicative. Though she makes it clear in her testimony that she never specifically said that she despised Creech, her descriptions of him and his actions make it clear that she did not approve of him either. ${ }^{59}$ This view would have been a fairly common one at the time given the socially accepted norms of courtship. Once a couple was engaged it was expected, of course, that they would spend more time together, however etiquette dictated that they not spend so much time together as to exclude any interactions with family and friends. They were expected to avoid "“pairing off" on all occasions," something that would render them "both the mark for silly jestings." It was imperative that the young woman not "devote her evenings exclusively to the chosen one, ignoring her family entirely."60 There was a fine line to be walked by courting couples and, according to the testimony of friends and family, Creech and Mary Ellen spent excessive amounts of time together and, as Jane Janes testified, "she hardly ever went out alone; Creech went out with her all the time.",61 This was not what the testimony of Creech would suggest, however.

Mrs. Wallenstine's testimony contradicted Creech's own testimony from the initial inquest. He placed the blame squarely with Mary Ellen and, secondarily, on Garrow. Creech used the trope of a single, promiscuous woman to attempt to gain sympathy with the jurors and was quick to make clear his lack of knowledge about both Mary Ellen's pregnancy and subsequent abortion. He described his questioning of Mary

\footnotetext{
${ }^{59}$ Testimony of Mrs. Maria Wallenstine, p. 26, Regina v. Garrow and Creech.

${ }^{60}$ Maude C. Cooke, Social Etiquette or Manners and Customs of Polite Society (London, ON: McDermid \& Logan, 1896), 134.

${ }^{61}$ Testimony of Jane Janes, p. 23, Regina v. Garrow and Creech.
} 
Ellen when she asked to go to Dr. Garrow rather than Dr. Hall. Her answer to him was that the family owed Dr. Hall a small bill for the "doctoring" of one of her brothers so he finally agreed to take her to Dr. Garrow's, still not aware for what the visit was needed. Creech told the jury that he waited outside for approximately twenty minutes and, when she emerged from Garrow's office, once again demanded to know what was wrong. According to Creech's testimony she told him that she was pregnant and he immediately asked her who was responsible. She apparently refused to tell him saying only "I deceived you." She then asked if he would "continue being the same way as [he] was" (he makes it clear that he was not only her friend but also the family's best friend) and, due to his "gentlemanly" character he agreed to help and remain a friend until the whole thing was over and done. ${ }^{62}$

In his own narrative, Creech's actions were exactly what one would expect from a gentleman of the time. His testimony clearly detailed his selfless attempts to gain medical treatment for Mary Ellen and ensure her survival, even after finding out she had supposedly cheated on him and committed one of the most heinous sins a young, unwed Victorian woman could commit. According to the customs of courting, he had acted just as he should by privately breaking the engagement with Mary Ellen and following the etiquette of courting almost to the letter, had promised to "preserve the strictest silence on the subject" as a gentleman would when the blame lay with the woman. ${ }^{63}$ Creech, in his own narrative and presentation of self, was noble, sacrificing, and loyal. In other words, he was a true Victorian gentleman. Here was a "Harry Creech" far different from the controlling, secretive, and possibly deceitful character of Mrs. Wallenstine's testimony.

\footnotetext{
${ }^{62}$ Victoria Daily Colonist, 14 December 1895; Testimony of Harry Creech, p. 7-9, Regina v. Garrow and Creech, file 1896/28, box 64, GR-0419, British Columbia Archives.

${ }^{63}$ Cooke, Social Etiquette, 136.
} 
Creech was clearly aware of his precarious position as simply the fiancé of Mary Ellen rather than her husband and, in giving his testimony as he did, attempted to not only create a more appealing character for himself but also distance himself from the situation further by placing the blame elsewhere. The person most readily available as a scapegoat was Mary Ellen. In this he followed the example of many men involved in abortions who felt that it was in their best interest to distance themselves or "feign ignorance." Being charged as an accomplice was a very real concern and Creech seemed to have understood this, as evidenced by his choice of testimony ${ }^{64}$ He portrayed Mary Ellen as both unfaithful and promiscuous, two of the worst traits for a Victorian woman to display. Such a tactic could backfire, however, if it was proven that the man involved was lying, a lesson Harry Creech would soon learn.

Mrs. Wallenstine was not the only witness who disliked Creech. Mary Ellen's brother, George Janes, testified that he had never like Creech and had "no use for Creech ever since he came to the house about my sister." George claimed to have made it clear to his sister that he disapproved of Creech and their courtship, though he also testified that he had never quarrelled with Creech and had no particular reason for his dislike. ${ }^{65}$ This unnamed reason might have had something to do with what some witnesses considered his inappropriate relationship with Mary Ellen. When Mrs. Wallenstine testified both to Creech's character and the character of Mary Ellen, she directly contradicted Creech's testimony. She claimed that Mary Ellen had a "kind and loveable disposition" and that she was both "pure and virtuous until she met Harry Creech." Both Wallenstine and another witness, Mrs. Lenora Castleton, spoke to the constant presence

\footnotetext{
${ }^{64}$ McLaren, "Illegal Operations," 803.

${ }^{65}$ Testimony of George Alfred Janes, p. 43, Regina v. Garrow and Creech.
} 
of Creech in the sick room and both saw his presence as "unnecessary, improper and ungentlemanly" as well as a usurpation of the household control which, as previously mentioned, should have rested with Mary Ellen's mother or even her brothers. This was quite clearly a view that was shared by the jurors at the inquest who also declared Creech's actions "ungentlemanly," citing his presence and actions within and around the Janes household as well as his attempts to "blacken her character." 66

Creech's involvement in Mary Ellen's situation was considered ungentlemanly in part for the two reasons stated above. The censure given by the jury, however, was also tied to Creech's role as a single man. Though he was engaged to Mary Ellen, they were not yet married and due to this he was judged according to different standards than he would have been had he been her husband. Society at the time and the court system all "tacitly recognized" the "right" of a married man to be involved or even in control of their wife's body, even when this included abortions. Bachelors were not awarded these rights as they belonged, in the case of single women, to the parents. ${ }^{67}$ As these were tacitly recognized rights, the jury did not explicitly describe this as part of their reasoning and final decision making. It would, however, have been understood at the time, by those in the courtroom as well as those following the progress in the newspapers, as simply the accepted situation of gender relations. It was understood by the witnesses and the members of the jury that Creech was not only inappropriately involved with Mary Ellen but, in an attempt to remove blame from himself, lied about his involvement. Again, this was not the way a Victorian gentleman was expected to act.

\footnotetext{
${ }^{66}$ Inquisition, Regina v. Garrow and Creech, p. 1-2, file 1896/28, box 64, GR-0419, British Columbia Archives; Victoria Daily Colonist, 17 December 1895.

${ }^{67}$ McLaren, "Illegal Operations," 805.
} 
Creech, as a white, middle-class Victorian male, was expected to adhere to the virtues of "muscular Christianity" which was the "hoped-for goal" that could be "attained through strict mental and physical discipline." ${ }^{68}$ Concepts of muscular Christianity, though emerging as a norm almost simultaneously with the social purity movement, had less to do with how one's actions were judged by the Christian god and more to do with how that man was judged by other members of society. Key elements of this masculinity included "physical vigor, energy and resolution, courage, and straightforwardness." As historian John Tosh explains, the masculinity of the Victorians "preserved its early modern origins as an external code of conduct, policed by one's peers." ${ }^{\prime 9}$ Though Creech held some of these attributes (at the very least he clearly showed resolution) he very much did not portray the equally important attributes of courage and straightforwardness. He blatantly lied both about his own actions and knowledge and the character of a young woman who, while not entirely innocent, was believed to have been simply led down the wrong path by a controlling and immoral man. Mary Ellen herself, then, was portrayed here as an archetype, that of the innocent and naïve maiden who had simply been led astray. This was the very type of women that the seduction laws discussed in the previous chapter had been put in place to protect. $^{70}$

In some senses, Creech was viewed to be more at fault even than Dr. Garrow, though Garrow was the one initially charged with the murder. Garrow was the first

\footnotetext{
${ }^{68}$ Frank Mort, Dangerous Sexualities: Medico-Moral Politics in England since 1830 (London: Routledge, 2000), 90.

${ }^{69}$ John Tosh, "Masculinities in an Industrializing Society: Britain, 1800-1914," Journal of British Studies, 44, 2 (April 2005), 335.

${ }^{70}$ Karen Dubinsky, “'Maidenly Girls' or 'Designing Women'? The Crime of Seduction in Turn-of-theCentury Ontario," in Gender Conflicts: New Essays in Women's History, edited by Franca Iacovetta and Mariana Valverde, Toronto: University of Toronto Press, 1992 speaks to these archetypes as does "The Seduction Act," The Legal News (19 June 1886), 81-82 which provides a contemporary discussion of them as they relate to the seduction bill.
} 
witness called by the coroner during the inquest and he described himself to the coroner (as had the other physicians) as "a duly qualified medical practitioner" and "resident on the Saanich road," a rural area just outside of the city proper and definitely outside of the disreputable areas discussed in Chapter Two. Though Garrow initially denied having known Mary Ellen he amended his statement after viewing the body, saying he had in fact seen that particular woman but had been given a different name. He recalled more specifically that she had told him she was originally from Salem, Oregon but now lived in Sydney. Garrow had also resided in Salem so he remembered the conversation and following this recalled his prescription for some "slight ailment" that she had, the nature of which he could not recall. The Coroner questioned him again asking if Mary Ellen had mentioned that she was pregnant and Garrow replied, rather carefully, "I don't think she did." The Coroner at the inquest seemed to find this unbelievable and questioned him again asking, “[a]re you sure?” to which Garrow replied, "I think I asked her; vomiting sometimes accompanies pregnancy, and she being a married woman - as she told me - I might have asked her, but I am not positive." 71

Through his testimony it would seem that Dr. Garrow, like Creech, attempted to offset some of the blame by pointing to the mistakes of Mary Ellen. She had not only lied to him about her name and marital status but was also unclear in her descriptions of her condition. Unlike Creech, however, Garrow was supported in some of his choices by his fellow medical practitioners who were also testifying in the court case. This was not an unusual thing and there were multiple cases where the doctors who were a part of the

\footnotetext{
${ }^{71}$ Victoria Daily Colonist, 14 December 1895; Testimony of John Kaye Garrow, p. 3-4, Regina v. Garrow and Creech.
} 
Mary Ellen Janes case worked together and testified together on other cases as well. ${ }^{72}$ As "regular" doctors they were generally trusted witnesses in courts of law where they were asked to defend their integrity, morality, and scientific work.

Dr. Ernest Hall (the second doctor that Dr. Francis Hall called in for consultation) was Garrow's most explicit supporter. He was acquainted with Garrow, though not closely, before the Janes case came to light. After the death of Mary Ellen, Dr. Hall requested that Garrow visit him in his office where he informed him of her death. Dr. Garrow did not recognize the name and only after Hall provided a brief description of her did he remember her. He claimed that she had introduced herself to him as a married woman by the name of Loveridge (or something of the sort, he could not remember) and that he had prescribed ergotine and used a sound to treat her intractable vomiting. Dr. Hall testified that he was led to believe that Garrow knew Mary Ellen was "suffering from the vomiting of pregnancy" though he could not claim for sure that Garrow had said as much directly to him. They discussed Garrow's treatment of Mary Ellen and though Hall made it clear to Garrow that he did not question it, he did question (in his meeting with Garrow and his testimony) the "propriety of his administering such treatment without consultation with another practitioner." Garrow replied to Hall's concern that he did not realize this was a custom in the profession and Hall remarked to him that it "was the moral aspect of the question that rendered consultation necessary." At multiple points in his testimony, however, he referred back to Garrow's intentions and adamantly claims that he acted "honourably." Garrow's testimony also seems to support this view as he

\footnotetext{
${ }^{72}$ Chapter Two: Marching to Zion (p. 91-120) from James Opp's Lord for the Body discusses multiple cases in Victoria during the first few years of the twentieth century that involved clashes between faith healers and regular physicians. These cases ended up in criminal court and, in many instances, the science of regular physicians was called into question.
} 
seemed unconcerned with the outcome of the inquest stating only that though the coroner's inquest might convict him, a "superior court would acquit for I have acted honourably and conscientiously." ${ }^{, 73}$ His claim can be related both to his honour as a man and his integrity as a professional, each of which came into play as he was judged by witnesses, judge, jury and newspaper readers.

Garrow's shock at the conclusion of the preliminary hearing of the charge of murder against himself and Creech was apparent in his courtroom reaction which was described as a "sensational incident" by a reporter for the Victoria Daily Colonist. When the court announced that he would have to stand trial he "broke out in a fierce torrent of profanity and abuse directed against the police, the medical profession and the Magistrate."74 This anger would most definitely have been in part due to his clear belief that he was in the right concerning his decisions in the Mary Ellen case. He felt that he had acted in a manner that fit with the socially accepted norms and professional requirements of the time and when his actions were not exonerated his shock and anger came through. Press attention especially to incidents like this within the trial illustrated the ability of reporters to slip back and forth between the reports they produced as opposed to the stories. Paul Rutherford identifies the difference between the two, stating; reports "typically...took the shape of a lawyer's brief, logical but hardly impartial, suited to the task of instruction and persuasion" while stories "smacked of melodrama and thus [were] the preferred technique of sensationalism."

\footnotetext{
${ }^{73}$ Testimony of Ernest Amos Hall, p. 13-14, Regina v. Garrow and Creech.

${ }^{74}$ Victoria Daily Colonist, 3 January 1896.

${ }^{75}$ Paul Rutherford, A Victorian Authority: The Daily Press in Late Nineteenth-Century Canada (Toronto: University of Toronto, 1982), 141-142.
} 
Regina v. Garrow and Creech, however in this instance, the tendency towards story in this portrayal of Garrow was unsurprising.

Where Garrow seemed to have failed in his defense lay with his lack of a consulting physician to corroborate his story as well as in other evidence that had come to light regarding the frequency of his use of ergotine prescriptions. The police called to the stand Mr. Charles Edwin Jones, a druggist with a shop on Government Street in Victoria. The police requested that Jones supply them with all of the prescriptions of ergotine that he had filled for Dr. Garrow within the last year. Jones refused stating that he was not trying to shield Garrow nor did he wish to obstruct a police investigation, but that he simply did "not feel justified in betraying the confidence of [his] patrons." "76 He was still required to testify, however, and he spoke of the twenty three prescriptions that Dr. Garrow had filled from his store within the last two years. In all of these prescriptions the only ingredient was ergot. ${ }^{77}$ Though testimony from the physicians had confirmed the controversial debates around the uses of ergotine, there were still those in the medical community who strongly felt that it was used for only two things; to produce an abortion or to "arrest hemorrhage.",78 The evidence from Jones added to other evidence of the seemingly negligent behaviour of Garrow in his decisions regarding Mary Ellen's treatment and was seen as quite damning, even given the testimony regarding Garrow's supposedly honourable intentions. Whether or not Garrow meant to perform an abortion and whether or not it was, in fact, the botched abortion that killed Mary Ellen was, in some senses, beside the point. He had allowed himself to become involved in a situation

\footnotetext{
76 Victoria Daily Colonist, 22 December 1895.

${ }^{77}$ Testimony of Charles Edwin Jones, p. 34, Regina v. Garrow and Creech, file 1896/28, box 64, GR-0419, British Columbia Archives.

${ }^{78}$ Victoria Daily Colonist, 27 December 1895; Testimony of John Lang, p. 11, Regina v. Garrow and Creech.
} 
involving abortion, its' criminalization, and all the morality and propriety that engulfed the issue.

The morality of mid to late nineteenth century called for very specific understandings of the relationships between men and women, doctors and patients, the population and the state. With the criminalization of abortions in the 1892 Criminal Code of Canada and the turn towards an intertwining of scientific discourse and morality as the new way of explaining and understanding the world, court cases involving abortions became key ways of viewing and understanding these particular social conditions. The Janes case serves this purpose well as it allows historians to better understand the language used by physicians and the court to describe abortions at the time, as well as what became the most important issues used in the decision making process of the judiciary. These discussions of abortion and control, gender, power, and sexuality all come through in the Janes case. One can clearly see the "ways in which dominant class, gender, and racial ideologies shaped official discourses and action, and relations between experts and clients." 79

What is most specifically apparent in these documents, however, is the way that morality, sexuality and the expected roles of men and women, even more so than scientific evidence and discourse, helped to shape the conclusion to the Janes case. The conflicting medical evidence was readily apparent in the testimony of the doctors, however, what also came through was the concern of Mary Ellen's friends and family over the intentions and honour of Creech. Those witnesses who were not part of the medical testimony especially tended to focus on issues of social propriety, morality and

\footnotetext{
${ }^{79}$ Iacovetta and Mitchinson, "Introduction," 6.
} 
sexuality while only one of the doctors mentioned his hesitation about Creech's story in his testimony. Though there were discussions of who Mary Ellen was as a person and a young woman, the testimony about her constructed her as an archetypical maiden in distress. She, along with Creech, was placed within the context of what was considered the norm at the time and this, in the end, became the key part of the trials' findings. Though she was at fault for giving in to immoral influences, she did so to a lesser degree than Creech was judged to have done. Not only was Creech judged more harshly in this scenario due to this own actions and lies, but Mary Ellen was possibly judged less harshly due to her death. As Karen Dubinsky points out, "the surest way to protect one's reputation was, sadly, to die. $" 80$ This was, in part, due to the belief that a good and moral girl would surely rather die than live with a sullied reputation.

In all of this the testimony of witnesses, doctors and the accused were compiled with other materials to construct a case file that preserved specific aspects of the trial. The Victoria Daily Colonist also compiled aspects of the story with blow-by-blow accounts of the trial from the first steps of the inquest to the appeal in the summer of $1896 .{ }^{81}$ On 22 July 1896 the paper reported that the "decision of the court of Crown Cases Reserved in the matter of Regina v. Garrow and Creech is expected to be handed down Monday next." 82 The case did not even end with the appeal, however, and on 20 January 1897 a request for the evidence and testimonies from the trial was sent to the Attorney-General's office by the Registrar for the Medical Council in Victoria. The return letter from the Deputy Attorney General Arthur G. Smith acknowledged the "receipt of [their] communication of the $20^{\text {th }}$ inst., in which you request a copy of the

\footnotetext{
${ }^{80}$ Dubsinky, Improper Advances, 20.

${ }^{81}$ Appeal, p. 6, Regina v. Garrow and Creech, file 1896/28, box 64, GR-0419, British Columbia Archives.

${ }^{82}$ Victoria Daily Colonist, 22 July 1896.
} 
evidence in the Garrow case for the inspection of the Medical Council." Smith explained that while there was no copy of the evidence that went before the jury, the judges would have been the only record, the evidence "given at the Coroner's Inquest and at the preliminary examination of Garrow [was] preserved in depositions. ${ }^{„ 83}$

This is just one of the ways that historians working with case files such as this can be reminded of the nature of what they are working with and the problems associated with such sources. Much of the information provided in the case file and even in the press reports of the trial was skewed by the information provided or even absent entirely because of particular ways of compiling and preserving evidence. In British Columbia specifically law reports were not even kept and published until the $1890 \mathrm{~s} .{ }^{84}$ Case files and press reports, then, serve as ideal ways to access past social norms and constructed ideas of masculinity, femininity and sexuality, especially when understood within the geographical spaces of Victoria and the politics of late-Victorian medicine. Dr. John Garrow and Harry Creech were both subjected to rigorous examination and were both found wanting, though Garrow was judged on both his masculinity as a man and as a professional while Creech's masculinity was judged as it existed in relation to Mary Ellen and their engagement. Those reading of their trial at the time through the Victoria Daily Colonist, and later through the law reports and testimonies, would have been able to extrapolate much about the expectations of late-nineteenth-century Victorian propriety and how ideas of courtship encoded clear etiquette and regulations for Victorian's (men and women) to follow.

\footnotetext{
${ }^{83}$ Arthur G. Smith, Letter, 27 January 1897, Regina v. Garrow and Creech, file 1896/28, box 64, GR-0419, British Columbia Archives.

${ }^{84}$ Clarkson, Domestic Reforms, 64.
} 


\section{Chapter Five \\ Conclusion: Gender, Sexuality, and the \\ Regional History of British Columbia}

When Alexander Featherstone bribed seven year old Thomas Price with twenty five cents and an offer of candy to show him his penis in April 1899, his decision to offer payment as a bribe, and his choice of location (the secluded upper level of the local mill) suggested that he knew what he was doing was considered immoral by the societal standards of the time. ${ }^{1}$ The information contained in this case file illustrates not only that there were moral standards regarding sexuality during the late-nineteenth century in British Columbia but also what some of these standards were. Featherstone's progression of interactions with the young Thomas, as illustrated in his own testimony and that of other witnesses, help historians to better understand and analyze the socially constructed norms and moralities of the time period, something that has yet to be done in any prolonged or in depth way for late-Victorian British Columbia. ${ }^{2}$

One of the key aspects in the Featherstone case was Featherstone's exhibition of what many Victorians believed were the uncontrollable sexual urges felt by all men. ${ }^{3}$ The contemporary use of the term "uncontrollable" is telling here as it was an urge thought to be present and irrepressible in all men, and yet there was also a double standard for those who were "true" Victorian gentleman. A true gentleman was capable of controlling the uncontrollable, of disciplining his own bodily urges. In the western

\footnotetext{
${ }^{1}$ Regina v. Featherstone, file 1899/38, box 1, GR-2355, British Columbia Archives.

2 Adele Perry, “'Oh I'm Just Sick of the Faces of Men': Gender Imbalance, Race, Sexuality, and Sociability in Nineteenth-Century British Columbia," BC Studies, 105/106 (Spring/Summer 1995), 37-40 discusses the sociability and sexuality of white women in late-Nineteenth century British Columbia but the secondary sources she cites, as with the sources I cite, are from studies of eastern Canadian experiences.

${ }^{3}$ See William Acton's The Functions and Disorders of the Reproductive Organs in Childhood, Youth, Adult Age, and Advanced Life: Considered in Their Physiological, Social and Moral Relations (London, England: Savill and Edwards, Printers, 1857) for a contemporary discussion of these supposedly uncontrollable male urges.
} 
world generally, and British Columbia specifically, notions of white masculinity were being altered in conjunction with the changes in society. Past understandings of masculinity seemed to fit either the rough-and-tumble working class or the strictly controlled upper class. With the shift towards industrialization, urbanization and, in western Canada especially, immigration, these concepts were in need of revision. Changing concepts of social norms meant that middle and upper class white men were now expected to show restraint and control, not only sexually but in all affairs, despite these "uncontrollable" and masculine urges. These changes are crucial to understanding how the province became what it is today.

In the archive documenting Regina v. Featherstone we not only see these manifestations of existing Victorian masculinities but also how, through public trials and press reports, Thomas Price, Featherstone, and those members of the population who would have had access to this information, would have been educated in the ways of proper and improper examples of Victorian masculinity. One of the themes in this thesis is how trials and the press reports about them contributed to the governance and regulation of these societal norms and the consequent dissemination of them throughout a changing society. Though the Featherstone case did not explicitly perpetuate concepts of Victorian femininity, as did most of the other case files that have been analyzed in this thesis, it still allows us as historians to better understand how ideas of gender and sexuality were constructed in late-Victorian British Columbia as well as illustrating how the law and the case files left behind can serve to give us important information about past times and places, information that may not have been accessible otherwise. 
In Chapter One of this thesis, I provided a discussion of Regina v. Featherstone as an example of how case files can serve historians as sources, despite the inherent problems that come with them as sources. I also discussed the context of late-nineteenth century British Columbia as the setting of my research, as well as how contemporary theories such as moral regulation and social control come into play, most particularly in the governing class's attempts to both change and maintain a status quo. Interwoven throughout this context is a discussion of some of the key historians who have influenced this work and continue to push the fields of feminist scholarship and British Columbian history forward to a more analytical discussion of an understudied time and topic in the historiography. All of this provided important framework and analysis for the work I did in the next three chapters of the thesis.

Chapter Two offered a mapping of the moral, physical, and legal geographies of late-Victorian British Columbia. This chapter also discussed nineteenth-century social purity movements as they originated in Great Britain and moved from there to eastern Canada and then, finally, to British Columbia where these ideas were disseminated and understood in varying ways between the coast and the interior. The context of the law and the legal system in British Columbia is also presented in this chapter as ideas about the frontier and the geographical environment of the province created a situation that differed greatly from the rest of the country. How all of this relates to courtship in the late-nineteenth century of British Columbia is key here, as is my discussion of where First Nations men and women fit (or more to the point do not fit) in my work due to their absence in my sources. In Chapter Two, then, I provided a more in depth look at the 
specific contexts of the social and legal spaces of late-Victorian British Columbia to prepare the reader for the specific examples used in the final two chapters of this thesis.

In Chapter Three I began by providing a broad look at the crime of seduction in Canada as it evolved from a simple tort in the early-1800s to a criminal offense by the late-1800s. I then narrowed the focus to an analysis of multiple seduction trials by using both case files and press reports. As we saw, contemporaries criminalized seduction to police more fully the life course of young adults (and youth) as well as to regulate sexuality. These broader changes, however, were once again eastern Canadian experiences and though legislation and these ideas did reach British Columbia, the experience there was different. Charges and trials emerged when courtship and the process of building a strong, heteronormative family was perceived as deviating from the "normal" course of things and went criminally awry. I also use these cases to provide evidence of the constructed nature of both masculinity and femininity and how, through most particularly the press reports but also through judicial diatribes and judgements, these concepts were reinforced and perpetuated in the society of late-Victorian British Columbia.

Chapter Four maintained a focus on this same line of investigation through an extended analysis of one particular case file: Regina v. Garrow and Creech. Though the charges laid against Dr. John K. Garrow and Harry Creech were charges of murder, the case actually revolved around the death of Mary Ellen Jane due to a botched abortion. As witness testimony from family and family friends sought to explain, Mary Ellen died at least in part from a courtship that had also gone awry. We also see the politics of medicine as the two men charged were judged for their action, or inaction, in the 
situation. The treatment of Mary Ellen, Creech and Garrow by those testifying in court as well as the judges and lawyers all provided evidence of how constructed ideas of femininity, masculinity, sexuality and the governance of a society are visible in these sources and, once again, how they were perpetuated and reinforced through the contemporary courts and press. Garrow was judged both as a man and a professional while the judgement of Creech focussed almost entirely on his masculinity as it existed in the particular setting of his personal relationship with Mary Ellen through courtship.

Using case files and press reports that focus on seduction and the Mary Ellen Janes abortion case specifically, then, I discussed how ideas of masculinity, femininity and sexuality were constructed and then disseminated through British Columbian society as a way to shape it in a particularly Victorian way. These constructions were informed by broader contexts of social purity and the British legal system, however, they were also more specifically informed by the quite self-conscious attempts of governing officials in British Columbia as they attempted to move away from the province's past, most specifically the early- and mid-nineteenth century understandings of British Columbia as a resource-based, racially diverse and very homosocial society. This then, is where more research must be done as this thesis uses mainly literature on eastern Canadian experiences of seduction and abortion to support arguments.

As discussed in the previous chapters of this thesis, one of the key elements of this perfected Victorian society was the heteronormative, nuclear family which, in turn, meant that the process of forming it (courtship) was of much concern to the governing classes of Victoria. As I have argued using the evidence from case files and the press, courtship and society generally was governed by those officials who felt that using the 
law would enable them to guide individuals through the process of courtship in the way they saw fit. What I also argue in this thesis, however, is that assumptions about gender and "normal" courtship were not natural categories but socially constructed ideas that were disseminated to society through court trials and press reports.

In making these arguments, I have sought to make a contribution to the regional history of British Columbia, particularly in the late-Victorian era. Scholars like Jean Barman, Tina Loo, Gillian Creese, Veronica Strong-Boag and Adele Perry have all worked to move towards more analytical and varied histories of British Columbia that take previously ignored or untapped aspects such as class, race, and gender into account. Their work, however, only takes us so far and the literature on white women in British Columbia, whether born there or having settled there, remains sparse, particularly as it relates to courtship or sociability in the late-nineteenth century of British Columbia. Adele Perry remains as one of the few scholars to examine these themes during this period. She has set the stage for another chapter to be written about white women and their experiences in this constantly shifting time period in British Columbian history.

Following the lead of both Perry and Jean Barman, especially, I have sought to demonstrate the centrality of gender and sexuality to the politics of state formation and society in British Columbia's regional history. Standards of sexuality, courtship, and the performance of gender in late-Victorian British Columbia all appeared in the seduction case files and the case of Mary Ellen Janes. Though I have pointed to some of the problems with using case files as sources in the introduction to this thesis, I have also, as discussed above, argued that they can provide large amounts of important information as long as these problems are acknowledged and understood. The legal documents and 
press reports that were generated around the trials analyzed in this thesis were all, in some way or another, conduits for the perpetuations and constructions of particular contemporary ideas about masculinity, femininity, and sexuality. These concepts were key aspects of the creation of a liberal state in a province that had previously served in the role of Canadian "frontier." Though this identity was still very much in existence, attempts to move away from it had begun to take more concrete shape only in the late 1890 s and even as the late as the early-twentieth century with the emergence of distinct reform groups like the Women's Christian Temperance Union (WCTU) and others.

When Robert Fleming was charged with the seduction of fifteen year old Annie L. Young in 1897 it was not a case where they had "hard evidence" of a seduction. It was, instead, about the fear of such an act possibly occurring and an attempt to stop it before it happened. Annie had gone on multiple carriage rides alone with Fleming and therein lay the problem. Though the information provided in the case file does not make it clear who made the charge against Fleming, it is obvious through Annie's testimony that it was not her and that she did not believe anything immoral or incorrect had occurred, either on her part or Fleming's. Once again, however, it was about the possibility of what could have occurred rather than what did occur. In cases like those of Regina v. Blythe and Regina v. Armour in Victoria, there was clear evidence of the crime and so the fear of possibility of courtship going criminally awry was, in those incidences at least, fulfilled. Regina v. Garrow and Creech alternatively gives us an example of how courtship could end in an even more drastic way; with the death of a young woman due to a botched abortion.

As I have argued at multiple points in this thesis and in this conclusion, case files provide historians with windows into late-Victorian constructions of immorality in two 
very unique areas of British Columbia. Not only that, but the content of these case files can, in some instances, bring us closer to the past through the emotion contained in sources like them. This is something that must be acknowledged and even embraced as there can be no complete objectivity in history, especially when dealing with sources as emotional and, at times, harsh as the ones analyzed in this thesis. Emotion was inevitably present during these acts of seduction. Emotions such as the supposedly uncontrollable masculine sexuality, the fear of some of the women, the possible enjoyment on the part of other women, and even the emotion of the friends and family who testified during the Mary Ellen Janes' case are both apparent and absent in the documents I have used to gain this evidence. The emotions that must have existed during these acts were muted and, in some senses, sterilized by the source framework of the legal system. The strict framework of bureaucracy and, in the case of the press reports, the artistic license taken by the journalists, creates a window into the past that is conversely emotional and emotionless at the same time. Readers, then, must decide how to analyze and acknowledge this when working with the sources. We must, as Ann Laura Stoler and Sarah de Leeuw argue, read "along the grain" and both acknowledge our subjectivity and the subjectivity of the framework it exists within. ${ }^{4}$

In this thesis I have used case files and press reports of particular trials to discuss the emotional and constructed nature of masculinity, femininity, and sexuality in latenineteenth century British Columbia and the ways in which the history of British Columbia can and must be expanded. With this evidence I have also argued that as

\footnotetext{
${ }^{4}$ Ann Laura Stoler, Along the Archival Grain: Epistemic Anxieties and Colonial Common Sense (Princeton and Oxford: Princeton University Press, 2009); Sarah de Leeuw, "Alice through the looking glass: emotion, personal connection, and reading colonial archives along the grain," Journal of Historical Geography, 38 (2012), 273-281.
} 
historians we must always strive to be analytical of both ourselves and our sources. Though complete objectivity is, for many, the main goal, this can never truly exist for historians, especially when looking at sources such as case files. Gender, race, class, space, and place all come into play when writing any history. Gender most particularly is present in all aspects of our lives and histories and should not be viewed, as some view it, as simply women's history but as an important aspect of history in general. All of these concepts are socially constructed and all work in conjunction with the other. Maintaining this awareness of how these concepts interact and exist in our history is essential. In the case of the seduction trials and the death of Mary Ellen Janes, then, there can be a tendency to look for those not always included in history, especially the history of British Columbia which has been constructed as a "white man's" province in past decades. ${ }^{5}$ This tendency, however important, can also push aside some of the key aspects of British Columbian history as it ignores the reality that is the presence of the white male and how this constructed identity and masculinity was a key aspect of the simultaneous construction of femininity and sexuality. Without one, we cannot fully understand the other, yet another reason that the historiography here must be expanded.

This thesis serves as an extension of past historiographical interventions as I have used it to attempt to further push conversations about British Columbian history in a more social-historical direction. With it I hope to problematize the history that has been done previously and the common assumptions about British Columbia and the men and women who lived there in the late-nineteenth century. Past conceptions of sexuality, gender, and

\footnotetext{
${ }^{5}$ Chad Reimer, Writing British Columbia History, 1784-1958 (Vancouver: UBC Press, 2009), 150-151; Patricia E. Roy's aptly titled book A White Man's Province: British Columbia Politicians and Chinese and Japanese Immigrants, 1858-1914 (Vancouver: UBC Press, 1989) looks at concepts of constructing white society particularly in relation to Asian immigration and these ideas can be understood in other contexts as well.
} 
race were not static but constantly changing as common discourses were through legislation and social interactions within society itself. All of this must be taken into account when writing the history of British Columbia, a history that has yet to be finished. 


\section{Bibliography}

\section{Primary Sources}

\section{Newspapers}

Revelstoke Herald, (1897-1905)

Tribune, (Nelson, 1892-1905)

Victoria Daily Colonist, (originally the British Colonist - 1858-1920)

\section{Case Files}

Attorney General Document Series, 1857-1966. GR-0419. File 1896/28, Box 64. British Columbia Archives.

“Regina v. Garrow and Creech.” British Columbia Law Reports (1896-1897): 61-66.

Revelstoke Police Court Case Files, 1891-1921. GR-2355. British Columbia Archives.

\section{Other Published Primary Sources}

Census 1881 - Province of British Columbia.

Census of Canada 1891 - Province of British Columbia.

Acton, William. The Functions and Disorders of the Reproductive Organs in Childhood, Youth, Adult Age, and Advanced Life: Considered in Their Physiological, Social and Moral Relations. London, England: Savill and Edwards, Printers, 1857.

"An Act to amend the Criminal Code, 1892, so as to make more effectual provision for the punishment of seduction and abduction," $3^{\text {rd }}$ Session, $8^{\text {th }}$ Parliament, 61 Victoria, 1898.

Begg, Alexander, ed. Begg and Lynch's Hand-Book and General Guide to British Columbia, vol. 1, no. 2. Victoria, BC: The B.C. Guide Publishing Company, 1893.

Cooke, Maude C. Social Etiquette or Manners and Customs of Polite Society. London, ON: McDermid \& Logan, 1896.

Criminal Code, 1892; Amended 1893. Montreal: Whiteford and Theoret, Law Publishers, 1894. 
Herring, Francis E. Canadian Camp Life. London: T. Fisher Unwin, 1900.

Pettipiece, R. P. Revelstoke City Directory, 1898, vol. II (May 1898).

Statutes of His Majesty's Province of Upper Canada Passed in the First Session of the Thirteenth Provincial Parliament of Upper Canada, Chap. VIII. $7^{\text {th }}$ William IV A.D. 1837 - First Session.

“The Seduction Act.” The Legal News (June 19, 1886): 194-195.

“The Seduction Bill.” The Legal News, Vol. VII, No. 11 (March 15, 1884): 81-82.

\section{$\underline{\text { Secondary Sources }}$}

Ajzenstadt, Mimi. "Cycles of Control: Alcohol Regulation and the Construction of Gender Role, British Columbia 1870-1925.” International Journal of Canadian Studies, 11 (Spring 1995): 102-118.

Azoulay, Dan. Hearts and Minds: Canadian Romance at the Dawn of the Modern Era, 1900-1930. Calgary: University of Calgary, 2011.

Backhouse, Constance. Colour-Coded: A Legal History of Racism in Canada, 19001950. Toronto: Toronto University Press, 1999.

—. "Desperate Women and Compassionate Courts: Infanticide in NineteenthCentury Canada." The University of Toronto Law Journal, 34, 4 (Autumn 1984): 447-478.

—_. "Nineteenth-Century Canadian Prostitution Law: Reflection of a Discriminatory Society." Histoire Sociale/Social History, 18, 36 (November 1985): 387-423.

—. Petticoats and Prejudice: Women and Law in Nineteenth-Century Canada. Toronto: Osgoode Society, 1991.

—. "The Tort of Seduction: Fathers and Daughters in Nineteenth Century Canada." The Dalhousie Law Journal, 10 (1986): 45-80.

Baldwin, Andrew, Laura Cameron, and Audrey Kobayashi. Rethinking the Great White North: Race, Nature, and the Historical Geographies of Whiteness in Canada. Vancouver: UBC Press, 2011.

Barman, Jean. "Taming Aboriginal Sexuality: Gender, Power, and Race in British Columbia, 1850-1900.” BC Studies, 115/116 (Autumn/Winter 1997/98): 237-266. 
- The West Beyond the West: A History of British Columbia. 3rd ed. Toronto: University of Toronto Press, 2007.

Baskerville, Peter. A Silent Revolution? Gender and Wealth in English Canada 18601930. Montreal and Kingston: McGill-Queen's University Press, 2008.

—. "'She Has Already Hinted at 'Board": Enterprising Urban Women in British Columbia, 1863-1896. Histoire Sociale/Social History, 52 (November 1993): 205-227.

Belshaw, John Douglas. “"Cradle to Grave: An Examination of Demographic Behaviour on Two British Columbian Frontiers." Journal of the Canadian Historical Association, 5, 1 (1994): 41-62.

Blouin Jr., Francis X. and William G. Rosenberg, eds. Archives, Documentation and Institutions of Social Memory: Essays from the Sawyer Seminar. Ann Arbor: University of Michigan Press, 2006.

Brownlie, Robin Jarvis and Valerie J. Korinek, eds. Finding a Way to the Heart: Feminist Writings on Aboriginal and Women's History in Canada. Winnipeg: University of Manitoba Press, 2012.

Burke, Monica. “'Creatures Devoid of Sense and Will': The Canadian Crime of Seduction and Its Early Victims." Unpublished MA Thesis, Department of Law, Carleton University, 2001.

Clarkson, Chris. Domestic Reforms: Political Visions and Family Regulation in British Columbia, 1862-1940. Vancouver: UBC Press, 2007.

Clarkson, Christopher. "Remoralizing Families? Family Regulation and State Formation in British Columbia, 1862-1940." Unpublished PhD Dissertation, Department of History, University of Ottawa, 2002.

Creese, Gillian and Veronica Strong-Boag. "Taking Gender into Account in British Columbia: More Than Just Women's Studies.” BC Studies, 105/106 (Spring/Summer, 1995): 9-26.

Dawson, Michael. Selling British Columbia: Tourism and Consumer Culture, 1890-1970. Vancouver: UBC Press, 2004.

De Leeuw, Sarah. "Alice through the looking glass: emotion, personal connection, and reading colonial archives along the grain." Journal of Historical Geography, 38 (2012): 273-281. 
Dean, Mitchell. Governmentality: Power and Rule in Modern Society. London: SAGE Publications, 1999.

_. "Michel Foucault: 'A Man in Danger."' In Handbook of Social Theory, edited by George Ritzer and Barry Smart, 324-338. London: SAGE Publications, 2001.

Derrida, Jacques. Archives Fever: A Freudian Impression. Chicago: Chicago University Press, 1996.

Domosh, Mona. "Toward a Feminist Historiography of Geography." Transactions of the Institute of British Geographers, 16 (1991): 95-104.

Driver, Felix. "Moral Geographies: Social Science and the Urban Environment in MidNineteenth Century England." Transactions of the Institute of British Geographers, 13 (1988): 275-287.

Dubinsky, Karen. Improper Advances: Rape and Heterosexual Conflict in Ontario, 18801929. Chicago: University of Chicago Press, 1993.

Dunae, Patrick. "Making the 1891 Census in British Columbia." Histoire Sociale/Social History, 31, 62 (1998): 223-239.

— . "Sex, Charades and Census Records: Locating Female Sex Trade Workers in a Victorian City." Histoire Sociale/Social History, 42, 84 (November 2009): 267297.

Dunae, Patrick A., Donald J. Lafreniere, Jason A. Gilliland and John S. Lutz. "Dwelling Places and Social Spaces: Revealing the Environments of Urban Workers in Victoria Using Historical GIS." Labour/Le Travail, 72 (Fall 2013): 37-73.

Erickson, Lesley. Westward Bound: Sex, Violence, the Law, and the Making of a Settler Society. Vancouver: UBC Press, 2011.

Flaherty, David H., ed. Essays in the History of Canadian Law: Volume 1. Toronto: University of Toronto Press, 1981.

Foster, Hamar. English Law, British Columbia; Establishing Legal Institutions West of the Rockies. Winnipeg: University of Manitoba, Faculty of Law, 1992.

Foucault, Michel. Power. Translated by Robert Hurley and others, edited by James D. Faubion and Paul Rabinow. London: SAGE Publications, 2001. - The Archaeology of Power and the Discourse on Language. Translated by A.M Sheridan Smith. New York: Pantheon Books, 1972. 
- The History of Sexuality: An Introduction, Volume 1. Translated by Robert Hurley. New York: Vintage Books, 1990.

Galois, Robert and Cole Harris. "Recalibrating Society: The Population Geography of British Columbia in 1881." The Canadian Geographer, 38, 1 (1994): 37-53.

Gidney, R.D. and W.P.J. Millar. Professional Gentlemen: The Professions in NineteenthCentury Ontario. Toronto: University of Toronto Press, 1994.

Harris, Cole. "How Did Colonialism Dispossess? Comments From an Edge of Empire." Annals of the Association of American Geographers, 94, 1 (March 2004): 165182.

- Making Native Space: Colonialism, Resistance, and Reserves in British Columbia. Vancouver: UBC Press, 2002.

- The Resettlement of British Columbia: Essays on Colonialism and Geographical Change. Vancouver: UBC Press, 1997.

Harris, Douglas C. Landing Native Fisheries: Indian Reserves and Fishing Rights in British Columbia, 1849-1925. Vancouver: UBC Press, 2008.

- Fish, Law and Colonialism: The Legal Capture of Salmon in British Columbia. Toronto: University of Toronto Press, 2001.

Hunt, Alan. Governing Morals: A Social History of Moral Regulation. Cambridge: Cambridge University Press, 1999.

Iacovetta, Franca and Wendy Mitchinson, eds. On the Case: Explorations in Social History. Toronto: University of Toronto Press, 1998.

Iacovetta, Franca and Mariana Valverde, eds. Gender Conflicts: New Essays in Women's History. Toronto: University of Toronto Press, 1992.

Kanakos, Jeannie L. "Negotiations to Relocate the Lekwungen, 1843-1911." Unpublished MA Thesis, Department of History, Simon Fraser University, 1982.

Knafla, Louis A., ed. Law and Justice in a New Land: Essays in Western Canadian Legal History. Toronto: Carswell Company Limited, 1986.

Larson, Jane E. "Women Understand so Little, They Call My Good Neighbour 'Deceit': A Feminist Rethinking of Seduction." Columbia Law Review, 93, 2 (March 1993): 374-472.

Loo, Tina. Making Law, Order and Authority in British Columbia, 1821-1871. Toronto: University of Toronto Press, 1994. 
_. "Of Moose and Men: Hunting for Masculinities in British Columbia, 18801939.” The Western Historical Quarterly, 32, 3 (Autumn 2001): 296-319.

Lutz, John Sutton. Makúk: A New History of Aboriginal-White Relations. Vancouver: UBC Press, 2008.

Lutz, John S. and Patrick A. Dunae, Jason Gilliland, Don Lafreniere, and Megan Harvey, "Turning Space Inside Out: Spatial History and Race in Victorian Victoria." In Historical GIS Research in Canada, edited by Jennifer Bonnell and Marcel Fortin, 1-24. Calgary: University of Calgary Press, 2014.

Maynard, Steven. "Rough Work and Rugged Men: The Social Construction of Masculinity in Working-Class History." Labour/Le Travail, 23 (Spring 1989): 159-169.

McLaren, Angus. "Illegal Operations: Women, Doctors, and Abortion, 1886-1939." Journal of Social History, 26, 4 (Summer 1993): 797-816.

McLaren, John. "Chasing the Social Evil: Moral Fervour and the Evolution of Canada's Prostitution Laws." Canadian Journal of Law and Society, 1 (1986): 125-166.

McLaren, John, Robert Menzies and Dorothy E. Chunn, eds. Regulating Lives: Historical Essays on the State, Society, the Individual and the Law. Vancouver: UBC Press, 2002.

Mitchinson, Wendy. The Nature of Their Bodies: Women and Their Doctors in Victorian Canada. Toronto: University of Toronto Press, 1991.

Mort, Frank. Dangerous Sexualities: Medico-Moral Politics in England Since 1830. London: Routledge, 2000.

Mouat, Jeremy. Roaring Days: Rossland's Mines and the History of British Columbia. Vancouver: UBC Press, 1995.

Opp, James. The Lord for the Body: Religion, Medicine and Protestant Faith Healing in Canada, 1880-1930. Montreal and Kingston: McGill-Queens University Press, 2007.

Peiss, Kathy and Christina Simmons, eds. Passion and Power: Sexuality in History. Philadelphia: Temple University Press, 1989.

Perry, Adele. "'Fair Ones of a Purer Caste': White Women and Colonialism in Nineteenth-Century British Columbia," Feminist Studies, 23, 3 (Autumn 1997), $501-524$. 
—. "From 'the hot-bed of vice' to the 'good and well-ordered Christian home': First Nations Housing and Reform in Nineteenth-Century British Columbia."

Ethnohistory, 50, 4 (Fall 2003): 587-610.

—. "“Oh I'm Just Sick of the Faces of Men': Gender Imbalance, Race, Sexuality, and Sociability in Nineteenth-Century British Columbia." BC Studies, 105-106 (Spring/Summer 1995): 27-44.

- On the Edge of Empire: Gender, Race, and the Making of British Columbia, 1849-1871. Toronto: University of Toronto Press, 2001.

Phillips, Jim and Tina Loo and Susan Lewthwaite, eds. Essays in the History of Canadian Law: Volume V, Crime and Criminal Justice. Toronoto: University of Toronto Press, 1994.

Pilarczyk, Ian C. “'So Foul a Deed': Infanticide in Montreal, 1825-1850." Law and History Review, 30, 2 (May 2012): 576-634.

Porsild, Charlene. Gamblers and Dreamers: Women, Men, and Community in the Klondike. Vancouver: UBC Press, 1999.

Reimer, Chad. Writing British Columbia History, 1784-1958. Vancouver: UBC Press, 2009.

Roy, Patricia. A White Man's Province: British Columbia Politicians and Chinese and Japanese Immigrants, 1858-1914. Vancouver: UBC Press, 1989.

Ruonavaara, Hannu. "Moral Regulation: A Reformulation.” Sociological Theory, 15, 3 (November 1997): 277-293.

Rutherford, Paul. A Victorian Authority: The Daily Press in Late Nineteenth-Century Canada. Toronto: University of Toronto Press, 1982.

Schwartz, Joan M. and Terry Cook. "Archives, Records, and Power: The Making of Modern Memory," Archival Science, 2, 1 (March 2002): 1-19.

Schwartz, Joanie. "The Criminal Code and the English Media in $19^{\text {th }}$ Century Canada." Unpublished MA Thesis, Department of Criminology, University of Ottawa, 1993.

Siegel, Reva. "Reasoning From the Body: A Historical Perspective on Abortion Regulation and Questions of Equal Protection." Stanford Law Review, 44, 2 (January 1992): 361-381.

Smart, Carol, ed. Regulating Womanhood: Historical Essays on Marriage, Motherhood and Sexuality. London: Routledge, 1992. 
Smith, Charlene P. "Boomtown Brothels in the Kootenays, 1895-1905." In People and Places: Historical Influences on Legal Culture, edited by Jonathan Swainger and Constance Backhouse, 120-152. Vancouver: UBC Press, 2003.

Steedman, Carolyn. Dust: The Archive and Cultural History. New Jersey: Rutgers University Press, 2001.

Stoler, Ann Laura. Along the Archival Grain: Epistemic Anxieties and Colonial Common Sense. Princeton and Oxford: Princeton University Press, 2009.

—. "Tense and Tender Ties: The Politics of Comparison in North American History and (Post) Colonial Studies.” Journal of American History, 88, 3 (2001): 829-865.

Strange, Carolyn and Tina Loo. Making Good: Law and Moral Regulation in Canada, 1867-1939. Toronto: University of Toronto Press, 1997.

Valverde, Mariana. The Age of Light, Soap and Water: Moral Reform in English Canada, 1885-1925. Toronto: University of Toronto Press, 2008.

Van Kirk, Sylvia. Many Tender Ties: Women in the Fur-Trade, 1670-1870. Norman: University of Oklahoma Press, 1980.

Ward, Peter. Courtship, Love, and Marriage in Nineteenth-Century English Canada. Montreal and Kingston: McGill-Queens University Press, 1990.

Weeks, Jeffrey. Sex, Politics, and Society: The Regulation of Sexuality Since 1800. Toronto: Pearson, 2012.

—. Sexuality and its Discontents: Meanings, Myths and Modern Sexualities. London: Routledge and Kegan Paul, 1985.

Zedner, Lucia. "Social Control." In The Blackwell Dictionary of Modern Social Thought, edited by William Outhwaite and Alain Touraine, 596-598. Malden, MA: Blackwell Publications, 2003. 